\title{
europa ethnica
}

Zeitschrift für Minderheitenfragen

\section{EDITORIA L}

Die Redaktion ......................... Seite

50

\section{BEITRÄ GE}

United Nations standard-setting regarding rights of minorities and indigenous peoples

(Asbjørn Eide) .....................................

The Responsibility to Protect Minorities: The Question of Protection by Kin-States

(Dan Kuwali and Gudmundur Alfredsson) Seiten

Indigenous rights at the United Nations: Their impact on international human rights standards (Alexandra Xanthaki) Seiten

Minderheitenschutz und Gleichheitsgebot im Wahlrecht (Ulrike Haider-Quercia) Seiten

Zwischen Anlehnung an Russland und Eigenständigkeit: Zur Sprachpolitik in Belarus'

(Mark Brüggemann) Seiten

\section{CHRON I K}

Nach der Abstimmung in Schottland

(Georg Kremnitz)............................. Seite

\section{AKTUELLES}

Literatur 


\section{Liebe Leserin, lieber Leser!}

Für dieses Heft konnten wir besonders renommierte Minderheitenexperten gewinnen. Gleich einleitend setzt sich Asbjørn Eide mit der Schaffung von Schutzstandards für Minderheiten durch die Vereinten Nationen auseinander, wobei er im Besonderen die Situation der indigenen Völker prüft. Er zeigt dabei auf, dass indigene Völker und Minderheiten im engeren Sinne über viele gemeinsame Schutzanliegen verfügen, gleichzeitig aber auch mit verschiedenen Lebenswirklichkeiten konfrontiert sind, die z.T. abweichende Schutzmechanismen voraussetzen. Mit den Verbürgungen der UN-Deklaration über die Rechte indigener Völker aus 2007 beschäftigt sich im Besonderen Alexandra Xanthaki. Dan Kuwali und Gudmundur Alfredsson behandeln das Thema „Schutzverantwortung (Responsibility to Protect - R2P) und Minderheitenschutz durch den Mutterstaat (Kin-State)“. Die Autoren betonen dabei, dass der Mutterstaat der Minderheiten einen wertvollen Beitrag zum Minderheitenschutz leisten kann, dass dieser Schutz aber nicht zu einer unilateralen Einmischung ausarten, sondern sich in einer „konstruktiven Unterstützung“ („constructive engagement“) erschöpfen sollte.

Ulrike Haider-Quercia beschäftigt sich in inrem Beitrag mit dem Titel „Minderheitenschutz und Gleichheitsgebot im Wahlrecht" mit einem Standardthema des Minderheitenrechts, nämlich mit der Frage, wie Vorrechte von Minderheiten im Wahlrecht mit dem Gleichheitsgrundsatz vereinbart sind. Sie legt dar, dass die fördernde Wahlrechtsprivilegierung zugunsten von Minderheiten unter dem Gesichtspunkt der Notwendigkeit, eine effektive Partizipation aller Bevölkerungsgruppen sicherzustellen, auf jeden Fall zu rechtfertigen ist.

Weitere Beiträge beschäftigen sich mit der Sprachpolitik in Belarus' (Mark Brüggemann) und mit dem jüngst durchgeführten Referendum in Schottland (Georg Kremnitz).

Wie immer runden zahlreiche Buchbesprechungen das Heft ab. Wer die „Europa Ethnica“ liest, kann darauf vertrauen, über die wesentlichen Publikationen zum Thema "Minderheiten“ und "Minderheitenschutz" informiert zu werden!

Eine spannende Lektüre wünscht Ihnen

Ihr

Europa-Ethnica-Team 


\title{
United Nations standard-setting regarding rights of minorities and indigenous peoples
}

\author{
Asbjørn Eide ${ }^{1}$ )
}

\section{Introduction}

The purpose of this article is to briefly describe and comment upon the emergence and evolution of standard-setting in UN regarding minorities and indigenous peoples. While the United Nations initially pursued an individualistic approach to human rights and was quite reluctant to deal with minority issues, this changed in the late 1960s when issues of minority rights got more attention, and in the 1970 s the problems faced by indigenous peoples also surfaced and became another major preoccupation in the human rights field.

As a consequence, two rather different tracks emerged within the United Nations, with two quite different outcomes in terms of standards adopted, with different sets of right-holders and constituencies. On October 18, 1992, the UN General Assembly adopted the United Nations' Declaration on the Rights of Persons Belonging to National or Ethnic, Religious and Linguistic Minorities ${ }^{2}$ ). Fifteen years later, on October 2, 2007, the General Assembly adopted the United Nations Declaration on the Rights of Indigenous Peoples (hereafter abbreviated UNDRIP) $)^{3}$ ). These two documents now exist side by side, but are very different in nature and apply to different sets of right-holders.

The questions addressed in this paper are the following: How and why did the separation between minorities and indigenous peoples happen? What are the differences in regard to the standards that are contained in each of these two declarations? To which groups or peoples are each of them applicable? How are indigenous peoples defined, in distinction to minorities?

This article first describes the initial reluctance of the United Nations to include minority rights among human rights. There is no mention of minority rights in the Universal Declaration of Human Rights (see below, section 2).

The next step in United Nations human rights practice was to move from its initial primary focus on the freedom and equality of every individual person, which necessitated a strong emphasis on prevention of discrimination, to a gradually increasing recognition of the need to protect minorities, not only against discrimination but also against intentional assimilation. On the positive side it was more widely accepted that most societies are multicultural and that this is a source of richness for society which required minority rights to be respected and ensured. While this may have been doubted by some, most states recognized that repression of minority identity was a harbinger of tension and violence, both nationally and internationally. Whatever concerns were the most influential, the outcome was a growing understanding that while integration in society is permissible and even desirable for purposes of social cohesion, assimilation is contrary to human rights and should be avoided, at least when the assimilation is due to pressure or denial of resources that makes cultural survival impossible (below, section 3).

The next step of relevance for this paper was the growing advocacy within the United Nations from around 1970 for special rights for indigenous peoples. It was argued that indigenous peoples constituted an entirely different category, a set of peoples with a very different history, different ways of life and relations to the natural environment, with different demands and needs. This advocacy resulted in a parting of ways between the elaboration of minority rights and of indigenous peoples' rights (section 4).

Consequently, the outcomes in terms of standards adopted were rather different for minorities and indigenous peoples. While practically all indigenous peoples can, if they so wish, claim to be minorities and thereby invoke minority rights, the opposite is not true: Most minorities cannot claim rights as indigenous peoples. A brief comparison of the standards is therefore of importance and is presented in section 5 , together with a brief description of the scope of application of each of these two instruments. Who are the right-holders or the beneficiaries of each of the two declaration?

Some concluding observations and reflections on future developments are found in section 6.

1) Asbjørn Eide is professor emeritus and former director, Norwegian Centre for Human Rights, Faculty of Law, University of Oslo; former chair, UN Working Group on Indigenous Populations, former Chair, UN Working Group on Minorities, and former President, Council of Europe's Advisory Committee on the Framework Convention on Rights of National Minorities.

2) UNGA resolution 47/135, http://www.ohchr.org/EN/Professionallnterest/Pages/Minorities.aspx.

3) UNGA resolution 61/295, available on the homepage of the UN High Commissioner on Human Rights, http://daccess-dds-ny.un.org/doc/ UNDOC/GEN/N06/512/07/PDF/N0651207.pdf?OpenElement. 


\section{Origins of universal human rights}

The preparations during World War II for the setting up of a new global organization - which in 1945 became the United Nations - started with the famous „Four Freedoms" speech in 1941 by the then President of the United States, Franklin D. Roosevelt. He presented visions of a future world order when the then ongoing World War II would be brought to an end. These four freedoms, to which reference is made in the preamble of the Universal Declaration of Human Rights, were freedom of speech, freedom of faith, freedom from want and freedom from fear.

The United Nations was established in 1945, at the end of World War II, in order to maintain international peace and to develop friendly relations between nations, and above all to achieve international co-operation in solving international problems of an economic, social, cultural, or humanitarian character and in promoting and encouraging respect for human rights and for fundamental freedoms for all without distinction as to race, sex, language, or religion.

The ideas set out in Roosevelt's Four Freedoms influenced the Atlantic Charter declared by Winston Churchill and Roosevelt in August 1941; the United Nations Declaration of January 1, 1942, and - more importantly - the United Nations Organization which was prepared during the war years and set up a few weeks after his death. His ideas and the spirit of his "New Deal” policy also greatly influenced the content of the Universal Declaration of Human Rights through the work of the American Law Institute in 1942-1944 of a Statement of Essential Human Rights. That statement was subsequently used as a source by the United Nations secretariat when in 1947 it presented the first draft of what on December 10, 1948, became the United Nations Declaration of Universal Human Rights ${ }^{4}$ ).

There is no reference to the rights of minorities, however, in the Universal Declaration of Human Rights. The issue was extensively debated, and several proposals for articles on minorities were presented by the Secretariat and by the delegations of Denmark, Yugoslavia, and the USSR in the drafting process from 1947 to 1948, but these did not find majority support (Eide; The Non-Inclusion of Minority Rights; 1999, Thornberry; International Law and the Rights of Minorities).

At the time of the League of Nations, human rights did not form part of international law. The only instruments available to protect members of minorities from discrimination were the minority treaties related to a select group of states (Eide: The Framework Convention in Historical and Global Perspective, in Weller 2005). The League of Nations had not even been prepared to deal with the question of racial discrimination (Lauren, Chapter 3: Racial Equality Requested - and Rejected)

After World War II, on the other hand, a general human rights system was created, which could be used by all individuals, whether they belonged to minorities or majorities. This was an entirely novel feature of interna- tional law; some have even argued that it constituted a revolutionary change of international law and relations. In the first draft for the Declaration prepared by the United Nations Secretariat, we can trace notions from the minority system under the League of Nations. A draft concerning rights of persons belonging to minorities were presented as follows:

In all countries inhabited by a substantial number of persons of a race, language or religion other than those of the majority of the population, persons belonging to such ethnic, linguistic or religious minorities shall have the right to establish and maintain, out of an equitable proportion of public funds available for that purpose, their schools and cultural institutions, and to use their language before the courts and other authorities and organs of the State, and in the press and public assembly ${ }^{5}$ ).

This was obviously inspired by the minority arrangements applied to selected countries in connection with the redrawing of border in Central and Eastern Europe after World War I. But there was much skepticism of those minority arrangements, particularly from most Western European countries and all the countries of the American hemisphere, as well as from the - then few - countries in Asia and Africa that were members of the United Nations by 1948.

In May 1948, the Chair of the Commission, Eleanor Roosevelt (U.S.A.), strongly argued against the inclusion of any minority rights provision. She referred to a regional conference held in Lima in 1938, where it had been affirmed that a system for the protection of ethnic, linguistic, or racial groups could not be applied in the Americas, "where minorities as such did not exist." Furthermore, this position had been repeated at the InterAmerican Conference on Problems of War and Peace, held at Chapultepec (Mexico City) in February 1945. The Conference had affirmed that, in the Americas, it was not desirable to have closed and homogenous groups which demanded the status of minorities ${ }^{6}$ ).

It became increasingly clear that the delegations from "new states" of the Americas (North and South) were opposed to any minority rights in the Declaration, while those from several other countries, mostly from Central and Eastern Europe and the Soviet Union were in favour. A proposal to omit any reference to minority protection from the draft Declaration was initiated by the United Kingdom, with the strong backing of the United States, and with China and India as co-sponsors, and adopted by the Commission. ${ }^{7}$ ) In the end, therefore, no provision

4) The predominant sources of inspiration for the Universal Declaration of the Four Freedoms speech in1941 and the preparations of "Essential Human Rights" under the American Law Institute in 1942-1944 have been described in Asbjørn Eide: Freedom from Need, pp. 163-167. in Scandinavian Studies in Law volume 55, published under the auspices of the Stockholm University Faculty of Law 2010

5) The Secretariat draft can be found in E/CN.4/AC1/3/Add.1.

6) $\mathrm{E} / \mathrm{CN} .4 / \mathrm{AC} 2 / \mathrm{SR} 9$.

7) Documents E/CN.4/99 and 104; discussions in E/CN.4/SR 73 and 74. 


\section{europa ethnica}

on minorities was included in the draft transmitted by the Commission to the General Assembly.

In the Third Committee of the General Assembly, the USSR, Yugoslavia and Denmark resubmitted proposals for minority protection. The Soviet draft included the rights of minorities to have their own ethnic or national culture, to establish their own schools, to receive teaching in their mother tongue, and to use that language in the press, at public meetings and in other official circumstances. The Danish proposal centered on the educational rights of minorities, while the Yugoslav proposal would have confirmed the individual's right to a nationality, as well as the rights of nations existing within States to enjoy equality in national, political, and social rights and to pursue the full development of their own ethnic culture and language. None of these were adopted.

On December 10, 1948, by UNGA resolution 217 (III) the Universal Declaration was adopted without any mention of minorities. But attached to that resolution was UNGA resolution $217 \mathrm{C}(\mathrm{III})$ with the following wording:

\section{"The General Assembly}

'Considering that the United Nations cannot remain indifferent to the fate of minorities,

'Considering that it is difficult to adopt a uniform solution for this complex and delicate question, which has special aspects in each State in which it arises,

'Considering the universal character of the Declaration of Human Rights,

'Decides not to deal in specific provisions with the question of minorities in the text of the Declaration,

'Refers to the Economic and Social Council the texts submitted ... and requests the Council to ask the Commission on Human Rights and the Sub-Commission on the Prevention of Discrimination and the Protection of Minorities to make a thorough study of the problem of minorities, in order that the United Nations may be able to take effective measures for the protection of racial, national, religious or linguistic minorities."

\section{The reemergence of minority rights}

As noted above, the UN General Assembly, having decided not to include any reference to minority rights in the UDHR, handed the matter over to the Commission and in particular the Sub-Commission on prevention of Discrimination and Protection of Minorities. This Sub-Commission, composed of independent experts regionally distributed, had been created in 1947 . One of its first tasks was to clarify its mandate, particularly the distinction between prevention of discrimination on one hand and the protection of minorities on the other This turned out to be a rather difficult task fraught with controversies.

During its first discussions in 1947 the Sub-Commission proposed elements on minority rights for the then ongoing drafting of the UDHR. In that context it defined „prevention of discrimination" as the prevention of any action which denied individuals or groups equality of treatment which they might wish, and interpreted the „protection of minorities" as the protection of non-dominant groups which generally wanted equality of treatment, while acknowledging or permitting a measure of differential treatment in order for the minorities to preserve their traditional characteristics, if they so desired $\left.{ }^{8}\right)$. There were some limitations envisaged, however: Differential treatment should not be allowed to come in conflict with the general welfare of the society as a whole, and the minorities should owe their individual allegiance to the state in which they lived, and should be citizens of that state.

In 1949, following the adoption of the UDHR with no reference to minority rights, the Sub-Commission continued to discuss the contents of its mandate and the kind of recommendations that should be made. For this purpose the UN secretariat issued a memorandum which was largely endorsed by the Sub-Commission, and which asserted that there are fundamental differences between the two objectives of the Sub-Commission ${ }^{9}$. The memorandum held that discrimination implied any act or conduct which had the intention or the effect to deny or prevent equality of treatment between certain individuals because they belonged to particular groups or categories of persons. The protection of minorities, by contrast, consisted of allowing or enforcing distinctions, voluntarily maintained by the group concerned, which to a large extent required positive action. In the elaboration of this point the Secretariat gave a number of examples that were drawn from the experiences with the minority regime systems under the League of Nations.

The Sub-Commission made considerable headway in the area of prevention of discrimination. It prepared a number of studies that were made use of in further standard-setting, and had a major role in the drafting of the International Convention on the Prevention and Elimination of All Forms of Racial Discrimination, which was adopted by the UN General Assembly in 1965.

Much greater difficulties were confronted by the SubCommission when it tried to pursue the other part of the mandate, the protection of minorities. In the Commission on Human Rights there was for a long time a resistance to proposals presented by the Sub-Commission. It was clear that there was no willingness among the majority of governments to revive and generalize the minority system of the League of Nations (Eide: The Sub-Commission, in Alston 1992).

The Sub-Commission had one victory in this field, however: It drafted for inclusion in the International Covenant on Civil and Political Rights the text that eventually became Article 27. In doing so the Sub-Commission was very cautious in not requiring positive or special measures by governments. The Sub-Commission text, which was inserted in the Covenant as Article 27, reads:

"Persons belonging to ethnic, religious or linguistic minorities shall notobe denied the right, in community with other members of their group, to enjoy their own 
culture, to profess and practice their own religion or to use their own language".

Having succeeded to have at least a modest minority right provision included in the Covenant in 1966, the Sub-Commission regained hope that more could be achieved, and restarted its efforts to study the problems of minorities. In 1967 a first effort was made but it turned out to be premature. One of the controversies was to define minorities. In order to do so, it was found important to study in greater depth the situations of minorities existing in different parts of the world. In 1971, the necessary authorization to conduct a study on the minority issues had been obtained, and the Sub-Commission appointed its Italian member, Professor Francesco Capotorti, to study the implications of Article 27.

His study was completed in $1977^{10}$ ) and remains the most thorough UN report on these controversial minority issues. In his preface to the study, Francesco Capotorti listed several obstacles to genuine acceptance by states of the idea of special protection of minorities (a) any international system of protection might become a pretext for interference in States' internal affairs; (b) the usefulness of a uniform approach around the world was questionable, (c) preservation of the collective identity of minorities could be a threat to State unity and stability, and (d) the need for special protection could be used to justify reverse discrimination. Taken as a whole, these considerations could explain the reluctance of many states to recognize rights of minorities; many governments preferred to have a free hand in regard to these issues.

Nevertheless, Article 27 of the Covenant had been adopted. By 1976 the Covenants entered into force. Rights of minorities now formed part of international human rights law, but the exact contents of those rights beyond the weak provision in Article 27 remained unclarified by 1977. Capotorti's recommendations were therefore the following: (a) the formulation of more elaborate international standards to supplement Article 27, (b) the development of new international methods for implementation, and (c) the adoption of bilateral or regional arrangements ${ }^{11}$ ).

The Commission on Human Rights did agree to set up a working group to follow up on the recommendations made by Capotorti, but with very little enthusiasm. One of the remaining stumbling blocks was the question of the definition of minorities. In 1984 the Commission asked the Sub-Commission to define minorities, a task presented to the Canadian member of the Sub-Commission, Jules Deschenes, who prepared a working paper on this topic. He argued that the definition should not include indigenous populations and non-citizens, and ended up with the following proposal for definition of minorities:

"A group of citizens of a State constituting a numerical minority and in a non-dominant position in that State, endowed with ethnic religious or linguistic characteristics which differ from those of the majority of the population, having a sense of solidarity with one another, motivated, if only implicitly, by a collective will to survive and whose aim is to achieve equality with the majority in fact and in law".

His definition did not find general support. Almost all agreed that indigenous populations should not be part of the minority definition; it had already been recognized that they should be given separate attention (see further below, section 4). Many argued also non-citizens could form part of ethnic or religious minorities and should therefore not be excluded from the definition. There were also a number of other controversial points in the debate following his working paper on the draft definition. The working group of the Commission continued its efforts to draft a declaration on minority rights but with little progress. In 1989, due in part to the escalation of ethnic conflicts, the Sub-Commission sought and obtained authority from ECOSOC to conduct a study on peaceful and constructive approaches to situations involving minorities, entrusted to the present author (Asbjørn Eide). In 1991, alarmed by the dramatic developments and increasing ethnic tensions in Central and Eastern Europe, the Commission finally adopted the draft Declaration on the rights of persons belonging to national or ethnic, religious and linguistic minorities and passed it on through ECOSOC to the UN General Assembly, which adopted in 1992 the Declaration on the Rights of Persons belonging to National, Ethnic, Religious and Linguistic Minorities. The declaration does not contain any definition of minorities. The Commission on Human Rights, in the context of its monitoring of the Covenant on Civil and Political Rights, adopted in 1994 a socalled General Comment (no. 23) on its interpretation of Article 27 which clarified many aspects. It made clear that also non-citizens could form part of minorities under Article 2712).

The study by Asbjørn Eide on peaceful and constructive approaches to situations involving minorities was completed in 1993. It contained a set of recommendations including a proposal to establish, within the SubCommission, a working group on minorities, comparable to the already ongoing working group on indigenous populations. Authorisation to do so was given by ECOSOC and the working group started in 1995. Asbjørn Eide was elected chairman and remained so for 10 years until he decided in 2004 no longer to run for election to the Sub-Commission.

The Commission on Human Rights decided in 2005 by its resolution 2005/79 to establish a mandate named "Independent Expert on minority issues". It has subsequently been renewed for three years at the time. The

8) Report of the Sub-Commission in 1947, E/CN.4/52 (1947).

9) Definition and Classification of Minorities, Memorandum submitted by the Secretary-General, E/CN.4/358 (1950) paras 29-38.

10) Subsequently published by the UN Centre for Human Rights (Geneva) as Study Series $5,<0147>$ Study on the Rights of Persons belonging to Ethnic, Religious and Linguistic Minorities", 1991.

11) Capotorti: The Rights of Persons belonging to Ethnic, Religious and Linguistic Minorities, E/CN.4/Sub.2/384 and Add. 1-6, 1977.

12) U.N. Doc. HRI/GEN/1/Rev.1 at 38 (1994). 


\section{europa ethnica}

mandate holder's mandate is (a) To promote the implementation of the Declaration on the Rights of Persons Belonging to National or Ethnic, Religious and Linguistic Minorities, including through consultations with Governments, taking into account existing international standards and national legislation concerning minorities; (b) To examine ways and means of overcoming existing obstacles to the full and effective realization of the rights of persons belonging to minorities; (c) To identify best practices and possibilities for technical cooperation with the Office of the High Commissioner, at the request of Governments; (d) To apply a gender perspective in his/ her work; and (e) To cooperate and coordinate closely, while avoiding duplication, with existing relevant United Nations bodies, mandates and mechanisms and with regional organizations.

\section{Standard-setting on the rights of indigenous peoples: From integration to self-determination}

International human rights as established at the end of World War II were based on the principles of equality and non-discrimination to ensure integration on an egalitarian basis. This was also the initial approach by the International Labour Organization (ILO), which already before World War II started to investigate the discrimination and exploitation of persons of indigenous origin ${ }^{13}$ ). A comprehensive study by the ILO in 1953 led to the adoption in 1957 of ILO Convention 107 on Indigenous and Tribal Populations. The focus of that convention was to facilitate a better integration of indigenous persons in the labour market through the elimination of discrimination and through improved vocational training.

Explicit attention by United Nations human rights bodies to the human rights of indigenous peoples started around 1970. Initiatives came both from the outside (particularly through the growing capacity of organizations of indigenous peoples) and from the inside of the UN system - the Secretariat and UN expert bodies.

This period in Latin America from around the mid-1960s to the 1990s was characterized by considerable political brutality and repressive military regimes - in Brazil, in Chile, in Argentina, in Uruguay and other countries. The situation of the indigenous went from bad to worse. International attention and concern was growing,

Within the human rights division of the UN secretariat, one member of the professional staff from Guatemala, Augusto Willemson Dias, was particularly concerned about the plight of the indigenous peoples ${ }^{14}$ ). When the Sub-Commission started to discuss the need for a study on the rights of minorities based on ICCPR Article 27 and requested authorization from the Commission on $\mathrm{Hu}$ man Rights to do so, he persuaded the Commission that authorization should be given also for a separate study, dealing with the human rights situation of indigenous populations. While the Sub-Commission appointed as Special Rapporteur for this study one of its members, Jose Martinez Cobo, the work with the study was in effect left to Willemson Dias.
Over the years Willemson Dias collected an enormous amount of documentation on the situation of the indigenous, and was in close contact with indigenous representatives throughout the world. Much credit for the success of these activities should go to Augusto Willemson Diaz, who later became a Human Rights Ombudsperson in his home country, Guatamala.

During the following years, several indigenous organisations were created or strengthened. The International Indian Treaty Council (IITC) and the World Council of Indigenous Peoples (WCIP) were in the forefront in the mobilisation of indigenous peoples world-wide. They were supported and assisted by a number of international non-governmental organisations such as the International Commission of Jurists, Survival International, and a range of other organisations.

Human rights organizations everywhere reacted strongly against the ongoing repressive acts in Latin America. An International NGO conference on Discrimination Against Indigenous Populations in the Americas was held in Geneva September 20-23, 1977. It was attended by more than a hundred indigenous representatives and a total of 400 participants representing diverse non-governmental organizations. The conference attracted great interest and attention including by many governments.

It adopted a Declaration of Principles for the Defence of the Indigenous Nations and Peoples of the Western Hemisphere and listed many of the concerns that were subsequently addressed by the Working Group on Indigenous Populations. It called for the recognition of indigenous peoples as nations, and for a guarantee of their rights. It demanded that treaties and agreements made with indigenous nations or groups should be respected and adhered to, and that no state should claim or retain the territories of the indigenous nations or groups, except such lands as may have been lawfully acquired by valid treaty or other contract freely made.

In 1982, the Sub-Commission set up a working group in indigenous populations, based on an initiative I took as its newly elected member in 1981 . I was elected the first chairman, succeeded in 1984 by Erica-Irene Daes from Greece. In my capacity as Chairman I decided that representatives of indigenous organizations should be given access to the working group with the right to speak and to present proposals. As a consequence, this became the first official international forum to which the indigenous people had access. They immediately started to make use of this opportunity, and at its peak the working group was attended by more than 1000 very active observers, most of them indigenous representatives. This had a strong impact on the direction of the work.

13) Swepston, Lee: Indigenous Peoples on the International Scene: A Personal Reminiscence. Chapter 25 in Eide. Möller and Ziemele: Making Peoples Heard. Essays on Human Rights in Honour of Gudmundur Alfredsson. Martinus Nijhoff Publishers, Leiden and Boston 2011.

14) Willemsen-Diaz, Augusto: How Indigenous Peoples' Rights reached the United Nations. In Charters, Claire and Stavenhagen. Rodolfo (eds.): Making the Declaration Work, The United Nations Declaration Rights of Indigenous Peoples. Published by the International Work Group for Indigenous Affairs, Copenhagen 2009. 
In its third session (1984) the WGIP decided to pursue the standard-setting activity by initiating the drafting of the declaration on the rights of indigenous peoples. This continued until 1993 when the WGIP finalized its draft. Parallel to the drafting, a wide range of studies were carried out to facilitate the drafting and to deepen the understanding of the issues involved. Erica Daes, who chaired the WGIP from 1984 until 2000, prepared the first drafts for the Declaration under discussion, based on the concerns expressed by the participants. The drafting by the Working Group of the Declaration is described by the Chairperson, Erika Daes, in Charters and Stavenhagen p. 48-77.

The working group finalized its draft of a declaration on the rights of indigenous peoples, which was endorsed by the Sub-Commission as a whole and then transferred to the political body concerned, the Commission on Human Rights.

A working group was established within the Commission which since 1995 met every year for more than a decade. Many governments were highly critical to some of the contents of the draft. Negotiations turned out to be much more difficult in the Commission (being a political body representing governments) than in the Sub-Commission (composed of independent experts). The draft lingered on from 1994 to 2006 and was still not adopted when the Commission was abolished, though much substantive work led by the Chairman of the Working Group had been done to smooth out the controversies.

\section{Adoption of the United Nations Declaration on the Rights of Indigenous Peoples (UNDRIP)}

The draft Declaration was adopted at the level of the new Human Rights Council in its first session in 2006, and was transferred to the General Assembly for final adoption. There, it met unexpected opposition primarily from some African states, which made it necessary to conduct additional negotiations between the indigenous caucus and the African states. This led to some changes in the previous draft which made it possible to have the Declaration adopted on September 13, 2007, by the General Assembly - 25 years after the first meeting of the WGIP.

The UN Secretary-General Ban Ki-moon called it "a triumph for indigenous peoples around the world". Ms. Vicky Tauli-Corpuz, then Chairperson of the UN Permanent Forum on Indigenous Issues, said in a press release that "The 13th of September 2007 will be remembered as an international human rights day for the Indigenous Peoples of the world, a day that the United Nations and its Member States, together with Indigenous Peoples, reconciled with past painful histories and decided to march into the future on the path of human rights."

The adoption became possible following a successful negotiation between the indigenous caucus and the African states, which led to 9 changes in the previous draft, most of them rather small and inconsequential, but two of them of greater significance.
The controversial provision on the right to self-determination in Article 3 remained unchanged, but its significance and scope has been significantly curtailed by a crucial addition to Article 46.1. In the previous draft, that Article contained the traditional savings clause 'Nothing in this Declaration may be interpreted as implying for any State, people, group or person any right to engage in any activity or to perform any act contrary to the Charter of the United Nations'. The new addition, which must have been one of the main concessions the indigenous had to make, has the following wording:

'or construed as authorising or encouraging any action which would dismember or impair totally or in part the territorial integrity or political unity of any state'.

This draws on the language of the 'Declaration on Principles of International Law Concerning Friendly Relations and Cooperation among States', U.N.G.A. resolution 2625 (XXV), 1970, which sets limits to the principle of self-determination. This text was repeated in the Vienna Declaration and Program of Action of 1993. As Article 46.1 of the adopted Declaration on the Rights of Indigenous peoples stands, it is more restrictive than the 1970 resolution. The impact of the change is to rule out any interpretation of the right to self-determination of indigenous peoples allowing for secession ('territorial integrity'). Demands for autonomy under the heading of self-determination under Article 3 and 4 of the Declaration will have to respect the political unity of the state, the implication of which may be difficult to determine in the abstract.

This addition is related to another change, the elimination of the former $14^{\text {th }}$ preambular paragraph, which read: 'Recognizing that indigenous peoples have the right freely to determine their relationships with States in a spirit of coexistence, mutual benefit and full respect'. That phrase is now out.

A change of great importance making it possible for the African states to support the Declaration is the addition of a new preambular paragraph (now the final paragraph in the preamble) with these words:

'Recognizing also that the situation of indigenous peoples varies from region to region and from country to country and that the significance of national and regional particularities and various historical and cultural backgrounds should be taken into consideration'.

In spite of these changes, the Declaration remains a very ambitious text, going very far in justifying claims for far-reaching autonomy, control by indigenous peoples over lands they use, a right to veto development projects under consideration by the national governments which the affected indigenous people consider harmful, and far-reaching claims for restitution or compensation. It is indeed a historic document.

Against this background there is no surprise that the Declaration was not adopted by unanimity. 143 states voted in favour, with 4 votes against and 11 abstentions. The 4 against were Australia, Canada, New Zealand and 


\section{europa ethnica}

the United States, countries with sizeable numbers of indigenous peoples. Subsequently, however, all of these four states have stated in various ways that they now recognize and support the Declaration. The 11 states that abstained included the Russian Federation and three African states (Burundi, Kenya and Nigeria). Practically all European states and all Latin American states voted in favour except Columbia which abstained.

\section{Reviewing the evolution, scope of application, issues of definition and contested situations}

This article has dealt with the evolution in standard-setting regarding minorities and indigenous peoples. It is useful at this stage to put it in its wider context, recognizing that human rights law has gone through a considerable evolution since the UDHR was adopted in 1948.

It started with general human rights to which everyone should be entitled, found in the Universal Declaration on Human Rights and elaborated in subsequent instruments, such as the two International Covenants of 1966 . These are rights of individual persons. They were adopted as universal rights, but the drafters were of course fully aware that the rights they included were not then universally recognized and even less respected and implemented.

In order to advance their universal acceptance, activities have been pursued in many directions within the United Nations and by regional organisations. Monitoring bodies have been established and procedures for promotion and implementation have been created. This is not the place to review these manifold developments, but only one will be briefly discussed: The recognition of human rights responsibilities to collectivities.

In the process of expanding the promotion of human rights, it became necessary to recognize that the individual rights had to take into account that there were cultural and social groups around the world whose members (or some of them) were eager to preserve their own cultural identity and in some cases also to preserve and protect the material conditions for that collective identity (particularly their land and natural resources).

In spite of initial reluctance, it was later accepted to adopt additional rights specific to persons belonging to national or ethnic, religious or linguistic minorities. These are now found in article 27 of the International Covenant on Civil and Political Rights (ICCPR), in the Declaration on the Rights of Persons belonging to National or Ethnic, Religious or Linguistic Minorities ("Minority Declaration"), and in several regional instruments dealing with the rights of persons belonging to minorities. They are formulated as rights of persons and therefore individual rights, but in order to respect, protect and fulfil those rights, States have some duties to minorities as collective entities because some of the rights can only be enjoyed in community with others.

A very different step was taken by the adoption of special rights of indigenous peoples. These are now found in the ILO Convention concerning Indigenous and Tribal Peoples in Independent Countries (No. 169) and in the United Nations Declaration on the Rights of Indigenous Peoples (UNDRIP). They are expressly formulated as rights of peoples and are therefore collective rights.

While the minority rights had their foundation in Article 27 of the International Covenant on Civil and Political Rights (ICCPR), the rights of indigenous peoples are linked more to Article 1 common to both the two International Covenants of 1966 (both the International Covenant on Civil and Political Rights and the International Covenant on Economic, Social and Cultural Rights). Common Article 1 deals with the right of peoples to selfdetermination and to sovereignty over their resources. This has now to some extent been recognised to apply also to indigenous peoples. UNDRIP article 3 explicitly recognizes the right of indigenous peoples to self-determination, but in practice and in the Declaration this is in reality limited to a right to autonomy.

\section{How do these different sets of rights relate} to each other?

The general human rights as listed in the Universal Declaration and elaborated in other instruments are individual human rights and can be demanded by every human being, including persons belonging to minorities, indigenous peoples and other peoples. These rights constitute the foundation of the human rights system. They are based on the two basic principles set out in the Universal Declaration: article 1 (that everyone is born free and equal in dignity and rights) and article 2 (that everyone is entitled to all the rights and freedoms set forth in the Declaration, without distinction of any kind, such as race, colour, sex, language, religion, political or other opinion, national or social origin, property, birth or other status).

These individual rights include the right to integrity of the person, freedom of action, due process rights, political rights, and economic, and social and cultural rights. Their major function is to ensure equal rights and dignity of every human as a basis for social integration.

The rights of persons belonging to minorities are additional rights to make it possible for those persons to enjoy their culture, to use their language, and/or to practice their religion, as provided for in the CCPR Article 27. They are addition to the foundational rights set out in the Universal Declaration. What is added in the Minority Declaration is that they shall have a right to participate effectively in cultural, religious, social, economic and public life (Minority Declaration, art. 2.2) and to participate effectively in decisions on the national and, where appropriate, regional level concerning the minority to which they belong or the regions in which they live (ibid., art. 2.3); to establish and maintain their own associations (ibid., art. 2.4); to establish and maintain free and peaceful contacts with other members of their group and with persons belonging to other minorities, as well as contacts across frontiers with citizens of other States to whom they are related by national or ethnic, religious or linguistic ties (ibid., art. 2.5). Nevertheless, 
they build on the individual human rights of the UDHR can be seen in Article 8.2 of the UN declaration on rights of minorities: "The exercise of the rights set forth in the present Declaration shall not prejudice the enjoyment by all persons of universally recognized human rights and fundamental freedoms."

These rights may be exercised by persons belonging to minorities individually as well as in community with other members of their group, without any discrimination, and no disadvantage shall result for any person belonging to a minority as a consequence of the exercise or non-exercise of the rights set forth in the Declaration (Article 3). The rights specific to indigenous peoples and members of indigenous peoples are spelled out in ILO Convention No. 169 and in UNDRIP. ILO Convention No. 169 and the indigenous declaration recognize their foundation in individual human rights. UNDRIP's Article 1 states that indigenous peoples have the right to full and effective enjoyment of all human rights and fundamental freedoms recognized in the Charter of the United Nations, the Universal Declaration of Human Rights and international human rights law.

The specific rights of indigenous peoples contained in the ILO Convention and UNDRIP are significantly different from those in the UN Minority Declaration. The difference can probably best be formulated as follows: whereas the Minority Declaration and other instruments concerning persons belonging to minorities aim at ensuring a space for pluralism in togetherness, the instruments concerning indigenous peoples are intended to allow for a high degree of autonomous development. Whereas the Minority Declaration places considerable emphasis on effective participation in the larger society of which the minority is a part (arts. 2.2 and 2.3), the provisions regarding indigenous peoples seek to allocate authority to these peoples so that they can make their own decisions (e.g. Convention No. 169, arts. 7 and 8; UNDRIP Articles. 4, 23 and 31). The right to participation in the larger society is in UNDRIP given a secondary significance and expressed as an optional right. Indigenous peoples have the right to participate fully, if they so choose, through procedures determined by them, in devising legislative or administrative measures that may affect them (UNDRIP Arts. 19 and 20). The underlying assumption must be that participation in the larger society is less important and less necessary when they have full authority of their own to make the relevant decisions for their own group and the territory they control.

Closely linked to this point is the difference concerning rights to land and natural resources. The Minority Declaration contains no such rights, whereas these are core elements in the ILO Convention (arts. 13-19) and in the UNDRIP (Articles 25-30). Other examples could be mentioned to explain the fundamental difference between the thrust of the rights of persons belonging to minorities and those of indigenous peoples. It is logically connected to the basic point that the minority instruments refer to rights of persons belonging to minorities, whereas those concerning the indigenous refer to rights of peoples.
What is the relationship between the minority rights and the rights of indigenous peoples, on the one hand, and the rights of peoples to self-determination set out in common article 1 to the International Covenants of 1966 , on the other? For the rights of persons belonging to minorities, the answer is simple: the relevant instruments provide no right to group (collective) selfdetermination. The rights of persons belonging to minorities are individual rights, even if they in most cases can only be enjoyed in community with others. The duties of the State in protecting the identity of minorities do, however, include a duty to accept and encourage conditions for a degree of non-territorial autonomy in regard to religious, linguistic or broader cultural matters. Effective participation by minorities may be facilitated by territorial devolution on democratic, not ethnic, grounds, but the relevant minority instruments do not impose a duty on States to devolve authority on a territorial basis. It is an option but not a duty.

Through the adoption of UNDRIP in 2007, indigenous peoples are now recognized to „peoples” also in the sense of Article 1 common to the two International Covenants. They are therefore to a large extent entitled freely to determine their political status and freely to pursue their economic, social and cultural development, and for their own ends freely to dispose of their natural wealth and resources without prejudice to any obligations arising out of international economic cooperation, based upon the principle of mutual benefit, and international law.

The ILO Convention No. 169 uses the term „peoples” but emphasizes in its article 1.3 that the use of that term shall not be construed as having any implications as regards the rights which may attach to the term under international law. Quite clearly, the aim was then (in 1989) to prevent „people” being used as an excuse to demand territorial separation. The UN declaration on indigenous peoples' rights goes a step further: Under its article 3 , indigenous peoples have the right of selfdetermination and by virtue of that right be entitled freely to determine their political status and freely pursue their economic, social and cultural development. This formulation, based on common article 1 of the International Covenants, was one of the most controversial elements in the draft declaration, but was finally accepted - but with the significant limitations that have been described above, made at the time of UNDRIP's adoption in 2007.

In reality, the rights of self-determination for indigenous peoples are circumscribed by UNDRIP Article 4 (“Indigenous peoples, in exercising their right to self-determination, have the right to autonomy or self-government in matters relating to their internal and local affairs, as well as ways and means for financing their autonomous functions").

Conceptually and in practice, territorial autonomy (which is the main element in UNDRIP) should be kept separate from cultural autonomy (to which also minorities can be entitled). 


\section{europa ethnica}

Their respective benefits and risks should be discussed. Regarding minorities in general, it is difficult to accept a principle of territorial autonomy based strictly on ethnic criteria, since this runs counter to the basic principles of equality and non-discrimination between individuals on racial or ethnic grounds. There are, on the other hand, strong arguments in favour of forms of cultural autonomy which would make it possible to maintain group identity. What is special for indigenous peoples is that the preservation of cultural autonomy requires a considerable degree of self-management and control over land and other natural resources. This requires some degree of territorial autonomy. The scope of and limits to such autonomy are difficult to specify, however, both in theory and on the ground in specific cases.

Whatever position one might take on this subject, which is likely to remain controversial for some time to come, it is clear that the problem of self-determination does not arise in regard to the Minority Declaration, which neither limits nor extends the rights that peoples might have under other parts of international law. The rights under that declaration may not be construed as permitting any activity contrary to the purposes and principles of the United Nations, including territorial integrity of States.

\section{The beneficiaries of the three categories of rights (human rights, minority rights indigenous peoples' rights)}

Every individual, including any person belonging to a minority or indigenous group, is entitled to the human rights set out in the Universal Declaration and can claim them in regard to any authority which exercises jurisdiction over her or him. Should minority groups or indigenous peoples have a degree of self-government, their authorities are therefore also obliged to respect and protect universal human rights within their jurisdiction. Special minority rights can be claimed by persons belonging to national or ethnic, linguistic or religious minorities, but also by persons belonging to indigenous peoples. The practice of the Human Rights Committee under article 27 of the ICCPR bears this out, in particular as expressed in its General Comment no. 23.

The rights of indigenous peoples under ILO Convention No. 169 and UNDRIP, can only be asserted by persons belonging to indigenous peoples or their representatives. Members of non-indigenous minorities cannot assert the rights contained in that convention.

The ILO Convention No. 169 defines the indigenous in article 1 (b) as those "peoples in independent countries who are regarded as indigenous on account of their descent from the populations which inhabited the country, or a geographical region to which the country belongs, at the time of conquest or colonization or the establishment of present State boundaries and who, irrespective of their legal status, retain some or all of their own social, economic, cultural and political institutions".

There is still no consensus as to which collectivities are the beneficiaries of the right to self-determination under article 1. There is general agreement that the right applies to the populations of non-self-governing territories as so determined by the relevant organs of the United Nations, and to the populations living in occupied territories. It also applies to the population as a whole of sovereign States. It now also applies to indigenous peoples, but with qualifications that were inserted before the UN Declaration on the Rights of Indigenous Peoples was adopted. Most important was the crucial addition to Article 46.1, described above in connection with the adoption process by the General Assembly in 2007.

When we look back at the whole negotiation process and the discussion of the criteria for special rights for minorities and indigenous peoples, we can see that the following elements have been prominent in the discussion:

Firstly, whether the group concerned is numerically inferior to the rest of the society. This would be a necessary element for minority rights - the main purpose of those rights is to compensate for their numerical weakness in the democratic process. But it is not necessarily conclusive for the rights of indigenous peoples. They may - when all of them taken collectively together as indigenous - constitute a national majority (as they do in Guatemala and Bolivia) but they may there be so fragmented and disempowered that the democratic processes do not protect them. Should they gradually recognize their common interests and values and decide to function as a collecitivity, they may become an operational majority and can then make use of the democratic system to protect their common indigenous identity and interests. This appears to be slowly happening in Bolivia, but not yet in Guatemala.

Secondly, whether they are non-dominant in society. This is a second, necessary component of minority rights, but the qualification must be made that the minority is sometimes dominant in a particular region of the country. If that region has a high degree of self-government and when this is actively used by the national minority to dominate policies in the region concerned, it is the local minority (or minorities) that need minority rights.

A subjective element is also necessary: Do the persons identify themselves as belonging to a minority? Not all of them do; some have become so fully integrated in the larger society that the minority issues are of little relevance to them. This may also be because the dominant society has made sufficient accommodation to the minorities so that there is no longer a significant minority tension in that society.

Thirdly, is the non-dominant group aboriginal to the national territory? Where they there before those that are presently dominant? This has been a commonly asserted criteria for being „indigenous”, but in many settings it may be doubtful, as pointed out by Feliz Ndahinda in his solidly documented investigation of the situations in Africa where claims of indigenousness have been made. (Ndahinda, Felix 2011).

But being aboriginal to the territory is not enough if the descendants of the initial group have already been integrated in the larger society. Unless they to some extent 
have a way of life and a culture which distinguish them from the dominant society, there is nothing to protect in terms either of minority or indigenous rights. A subjective element is also here necessary: Do the persons identify themselves as belonging to a particular group that differs in some respect from that of the minority (typically: in terms of language, religion, historical traditions and culture)?

The crucial difference separating indigenous peoples from minorities is that, in addition to having a credible claim of aboriginality, they have maintained elements of a traditional culture involving a special relationship to land and/or natural resources and that on that basis they self-identify as indigenous people.

\section{Concluding observations}

A dual track emerged in United Nations human rights standard-setting from around 1970, one focussing on minorities and the other on rights of indigenous peoples. It took some time to recognize that general human rights, which have a distinctly integrative function, needed to be supplemented by standards that could take into account the diversities in society, whether temporarily or for ever Minority rights are formulated as the rights of individuals to preserve and develop their separate group identity within the process of integration. Persons belonging to minorities often have several identities, however and many of them participate actively in the common domain, which means that their minority situation may be declining in importance for them.

We must keep in mind that minorities and persons belonging to them generally have two concerns: One is to be treated as equals to other members of society, being freed from discrimination and marginalization; the other is to have or be given the necessary space to maintain or develop their collective identity. But not all minorities place the same emphasis on those two concerns. For some minorities, the main priority is the search for equality. For others, the quest for a protected space of collective identity is the dominant concern. For purposes of illustration it can be argued that for the Roma in Europe the main concern at present is to obtain equality and bring discrimination to an end, while for the Hungarians living in countries that are neighbours to Hungary (mainly Slovakia, Romania, Serbia) their main concern is with the preservation and development of their Hungarian cultural identity.

Indigenous rights, on the other hand, tend to consolidate and strengthen the separateness of these peoples from other groups in society. The underlying assumption is that persons belonging to indigenous peoples have a predominantly indigenous identity and participate less in the common domain.

What is normally held to distinguish indigenous peoples from other groups is their prior settlement in the territory in which they live, combined with their maintenance of a separate culture which is closely linked to their particular ways of using land and natural resources.
The usefulness of a clear-cut distinction between minorities and indigenous peoples is debatable. ${ }^{15}$ ) The SubCommission played a major role in separating the two tracks. One question is whether the distinction has global relevance. It has been argued (Jose Bengoa, expert from Chile member of the working group on minorities of the UN) that the approach to the drafting of minority rights has been influenced mainly by European experience and that it therefore is profoundly Eurocentric, whereas the drafting of indigenous rights has been influenced mainly by developments in the Americas and in the Pacific region (the "blue water doctrine") and therefore is, as he put it, "America-centric".

The "blue water doctrine" held that the indigenous are those people beyond Europe who lived in the territory before European colonization and settlement, and who now form a non-dominant and culturally separate group in the territories settled primarily by Europeans and their descendants. During the process of negotiating the draft, it became clear that this was too narrow an approach. The Sami of northern Scandinavia and the Arctic peoples of the Russian Federation are widely held to be indigenous in spite of the fact that they are not covered by the „blue water doctrine”. Norway has ratified ILO Convention No. 169 on the understanding that the Sami are indigenous as defined in article 1 of that Convention. The „blue water” doctrine is also inapplicable to the situations in Africa and Asia. Other criteria have to be used, and the debate is still ongoing.

An important contribution to this debate has been given by Felix Ndahinda who explains why the notion of „indigenousness" and the related rights is a highly contested legal framework for empowerment of „marginalized communities" in Africa. This explains why UNDRIP met resistance in the UN General Assembly in 2006, and could only be adopted after negotiations with African states and modifications made in the text ${ }^{16}$ ).

Another question is whether all minorities, and all indigenous peoples, should be treated alike, or whether differentiation is required both between minorities and between indigenous groups. For persons of indigenous origin who have migrated to urban areas their separate identity may have to be combined with integration on a basis of equality within the city. Similarly, the needs of minorities who live compactly together and possibly form the majority in a particular region of a country are quite different from the needs of persons belonging to minorities who live dispersed, most of them in cities where persons of many different ethnic origins mingle together.
15) On this point, see Kymlicka, Will: Beyond the Indigenous-Minority Dichotomy? Chapter 8 in Allen and Xanthaki, 2011

16) Ndahinda, Felix Mukwiza: Indigenousness in Africa. A contested Framework for Empoerment of "Marginalised" Communities. T.M.C. Asser Press. 2011 


\section{europa ethnica}

\section{References and supplementary readings}

Allen, Stephen and Xanthaki, Alexandra (eds.) (2011): Reflections on the UN Declaration on the Rights of Indigenous Peoples. Oxford: Hart Publishing.

Alston, Philip (ed.) (2011): The United Nations and Human Rights - A critical appraisal. Oxford: Clarendon Paperbacks.

Anaya, S. James (2011): Indigenous Peoples in International Law. Second Edition. Oxford University Press.

Anaya, S. James (2011): The Right of Indigenous Peoples to Self-Determination in the Post-Declaration Era. In: Charters and Stavenhagen.

Barume, Albert (2009): Responding to the Concerns of the African States. In: Charters and Stavenhagen.

Capotorti, Francesco (1978/1991): Study on the Rights of Persons belonging to Ethnic, Religious and Linguistic Minorities. E/78.XIV.1. Also published as U.N. Human Rights Series no.5, 1991.

Carmen, Andrea (2009): International Indian Treaty Council Report from the Battle Field - the Struggle for the Declaration. In: Charters and Stavenhagen.

Charters, Claire and Stavenhagen, Rodolfo (eds.) (2009): Making the Declaration Work: The United Nations Declaration on the Rights of Indigenous Peoples. Published by the International Work Group for Indigenous Affairs, Copenhagen.

Cobo, Martinez (1986): Study of the Problem of Discrimination against Indigenous Populations, UN Doc. E/CN.3/ Sub2/1986/7 and adds. 1-4.

Daes, E. (2001): Indigenous Peoples and their Relationship to Land. UN Document E/CN.4/Sub.2/2001/21.

Daes, E. (2011): Protection of the Heritage of Indigenous Peoples. UN Publication, Sales No. E.97.XIV.3.

Daes, Erica-Irene (2011): The UN Declaration on the Rights of Indigenous Peoples. Background and Appraisal. In: Allen and Xanthaki, chapter 1.

Daes, Erica-Irene (2011): Principal Problems Regarding Indigenous Land Rights and Recent Endeavours to Resolve Them. Chapter 27 in: Eide, Möller and Ziemele.

Daes, Erica (2009): The Indigenous Peoples, the Working Group on Indigenous Populations and the Adoption of the UN Declaration on the Rights of Indigenous Peoples. In: Charters and Stavenhagen: Making the Declaration Work, IWGIA.

Dunbar Ortiz; Roxanne (2014): The first ten years, from study to working group, 1972-1978. In: Dunbar Ortiz, Sambo Dorough et al.

Dunbar Ortiz, Sambo Dorough et al. (2014): Indigenous peoples' rights in internatonal law: Emergence and application. Forthcoming, IWGIA and Galdu.

Eide, Asbjørn (1999): The Non-Inclusion of Minority Rights: Resolution 217 C(III). In: Gudmundur Alfredsson and Asbjørn Eide: The Universal Declaration of Human Rights - A Common Standard of Achievement. Kluwer Law International.

Eide, Möller and Ziemele (2011): Making Peoples Heard. Essays on Human Rights in Honour of Gudmundur Alfredsson. Leiden and Boston: Martinus Nijhoff Publishers.

Eide, Asbjørn (2011): Prevention of Discrimination, Protection of Minorities, and the Rights of indigenous Peoples. Challenges and Choices. In: Eide, Möller and Ziemele Chapter 23.

Eide, Asbjørn (1992): The Sub-Commission on Prevention of Discrimination and Protection of Minorities, in: P. Alston, ed.: The United Nations and Human Rights. A Critical Appraisal, Oxford: Clarendon Paperbacks, pp. 211-264.
Eide, Asbjørn (2005): The Framework Convention in Historical and Global Perspective. In: Weller, Marc (ed.): The Rights of Minorities, A Commentary on the European Framework Convention for the Protection of National Minorities. Oxford: University Press.

Eide, Asbjørn (2004): The role of the United Nations Working Group on Minorities. Chapter 2 in: „Mechanisms for the implementation of minority rights" Council of Europe Publishing.

Eide, Asbjørn (2009): The Indigenous Peoples, the Working Group on Indigenous Populations and the Adoption of the UN Declaration on the Rights of indigenous Peoples. In: Charters and Stavenhagen, pp. 32-47.

Eide, Asbjørn (2013): Ensuring Social and Economic Rights of National Minorities through the Work of the Advisory Committee on the Framework Convention. Chapter 2 in: Malloy and Caruso.

Erueti, Andrew (2011): The International Labour Organization and the Internationalisation of the Concept of Indigenous Peoples. Chapter 4 in: Allen and Xanthaki.

Hofmann, Rainer and Gauthoer, Juri Alstair (2011): Indigenous Peoples and the Right to Development. Chapter 26 in: Eide, Möller and Ziemele.

Kipuri, Naomi (2009): The UN Declaration on the Rights of Indigenous Peoples in the African Context. In: Chartes and Stavenhagen.

Kymlicka, Will (2011): Beyond the Indigenous/Minority Dichotomy? In: Allen and Xanthaki, chapter 8.

Koivurova, Timo (2011): Redefining Sovereignty and Self-Determination through a Declaration of Sovereignty: The Inuit Way of Defining the Para meters for Future Arctic Governance. Chapter 29 in: Eide, Møller and Zimele.

Lauren, P.G. (1978): Power and Prejudice: The Politics of Racial Discrimination. Boulder, CO: Westview Press.

Malloy, Tove and Caruso, Ugo (eds.) (2013): Minorities, their Rights, and the Monitoring of the European Framework Convention for the Protecion of National Minorities. Leiden and Boston: Martinus Nijhoff Publishers.

Martinez, M. Alfonso (1999): Study on treaties, agreements and other constructive arrangements between States and indigenous peoples. UN Doc. E/CN.4/Sub.2/1999/20.

Ndahinda, Felix Mukwiza (2011): Indigenousness in Africa. A contested Framework for Empoerment of "Marginalised" Communities. T.M.C. Asser Press.

Roy, Chandra K. (2009): Indigenous Peoples in Asia: Rights and Development Challenges. In: Charters and Stavenhagen. Stavenhagen, Rodolfo (2009): Making the Declaration Work. In: Charters and Stavenhagen.

Swepston, Lee (2011): Indigenous Peoples on the International Scene: A Personal Reminiscence. Chapter 25 in: Eide, Möller and Ziemele.

Tomei, M. and Swepston, L. (1996): Indigenous and Tribal Peoples: A Guide to ILO Convention 169. Geneva: International Labour Organisation.

Thornberry, Patrick (2011): Integrating the UN Declaration on the Rights of Indigenous Peoples into CERD practice. In: Allen and Xanthaki, chapter 3.

Thornberry, Patrick (2002): Indigenous peoples and human rights. Manchester: Manchester University Press

Thornberry, Patrick (1991): International Law and the Rights of Minorities. Oxford: Clarendon Press.

Willemsen-Diaz, Augusto (2009): How Indigenous Peoples Rights reached the United Nations. In: Charters and Stavenhagen. 


\title{
The Responsibility to Protect Minorities: The Question of Protection by Kin-States
}

\author{
Dan Kuwali*) and Gudmundur Alfredsson**)
}

\section{Introduction}

Identity-based tensions have been present in many of the violent conflicts that have required United Nations (UN) Security Council action since the end of the Cold War. More often than not, minorities have been principal victims before, during and after these conflicts. There is no doubt that the human rights situations facing many minorities cause many of these conflicts. According to the UN High Commissioner for Human Rights, "[m]inorities in all regions of the world continue to face serious threats, discrimination and racism, and are frequently excluded from taking part fully in the economic, political, social and cultural life available to the majorities in the countries or societies where they live. ${ }^{1}$ )

States have a responsibility to protect all people residing in their territory, be they members of majorities or minorities or indigenous peoples. This principle of protection of populations at risk lies at the heart of the human rights rules of equal rights and non-discrimination and of the political commitment concerning the responsibility to protect (R2P). The latter was adopted by all the UN Member States at the 2005 World Summit. The notion of R2P emerged in order to avert atrocity crimes in the form of genocide, war crimes and crimes against humanity, following the failure of the international community to protect people targeted by their fellow citizens or by the State, such as the 1994 genocide in Rwanda where at least 800000 Tutsis and Hutu sympathizers were killed and the 1995 slaying of more than 7000 Bosnian Muslim boys and men during the Srebrenica massacre.

Given that States often have borders that divide people sharing ethnic, cultural, linguistic, religious and/or historic bonds, neighboring or nearby States may have strong ethnic, cultural, religious or linguistic links to the minority population across their borders. The international community cannot and should not stand by when the fundamental rights of minorities are being violated but, at the same time, the protection of national minorities cannot and should not be invoked by kin-States as a justification for intervention in violation of the principles of State sovereignty and territorial integrity. ${ }^{2}$ ) The controversial and divisive effects of a kin-State illustrate the dilemma emanating from the involvement of a kin-State in the implementation of the responsibility to protect minorities beyond its borders. $\left.{ }^{3}\right)$ Although kin-States can provide assistance and fill capacity gaps as long as these are aimed at preventing and resolving minority tensions, their interference and intervention in the domestic affairs of other States also invites trouble by presenting a destabilizing threat to internal and regional peace and security. ${ }^{4}$ )

The international community has long grappled with the question of how to protect minorities, not least where kin-States are involved. ${ }^{5}$ ) As observed on the website of the OSCE High Commissioner on National Minorities, minority communities that cross State borders "can serve as a bridge and contribute to friendly relations, but the potential for tension can also exist, especially when states claim protection of their "kin" abroad, making these issues a matter of legitimate international concern". ${ }^{6}$ ) This approach of sovereignty, jurisdiction and responsibility of the State in which a minority resides is underlined in the Bolzano Recommendations on National Minorities in Inter-State Relations adopted under the auspices of the High Commissioner in $2008^{7}$ ) and in a draft Report on the Preferential Treatment of National Minorities by their Kin-State issued in 2001 by the Council of Europe's Commission for Democracy through Law - Venice Commission. ${ }^{8}$ )

*) Post Doctoral Fellow, Centre for Human Rights, University of Pretoria and Fellow, Carr Center for Human Rights Policy, Harvard Kennedy School of Government, Harvard University.

**) Law Professor; University of Akureyri and the China University of Political Science and Law.

1) United Nations Office of the High Commissioner for Human Rights, "Minorities", available at:<http://www.ohchr.org/EN/Issues/Minorities/ Pages/MinoritiesIndex.aspx>(accessed 1 September 2014).

2) Shapovalova Olena and V.N. Karazin Kharkiv, "The Responsibility to Protect Minorities," National University (Ukraine) Summer School, available at: <http://www.summerschooles.uni.lodz.pl/wgrane_pliki/theresponsibility-to-protect-minorities.pdf $>$ (accessed 3 September 2014).

3) Turner and Otsuki, “The Responsibility to Protect Minorities and the Problem of the Kin-State", p. 1.

4) Olena and Kharkiv, "The Responsibility to Protect Minorities" note 2 above.

5) As above. See also Daniel Moeckli, Sangeeta Shah, and Sandesh Sikumaran, International Human Rights Law, Oxford: Oxford University Press, 2010, pp. 365-837.

6) Organization for Security and Co-operation in Europe (OSCE), "The Bolzano/Bozen Recommendations on National Minorities in Inter-State Relations and Explanatory Note", June 2008, available at:<www.osce.org/hcnm>. 7) OSCE, "The Bolzano/Bozen Recommendations on National Minorities", as above.

8) Council of Europe, Report on the Preferential Treatment of Nationa Minorities by their Kin-State, adopted by the Venice Commission at its 48th Plenary Meeting, Venice, 19-20 October 2001, available at: 


\section{europa ethnica}

Inadequate protection of the rights of such minorities may raise grievances that can be and have been exploited by violent extremists or by neighboring or kin-States, often with ulterior motives. History has shown that when States take unilateral steps to protect 'their kin' outside their borders, there is a risk of tension and violent conflicts. The issue of German minorities in Poland and Czechoslovakia prior to WWII was abused as a pretext for aggression in those countries by Nazi Germany, and the Russian Federation seeks to justify the 2014 annexation of Crimea and other Russian involvement in the Ukraine by reference to fellow Russians.

The international approach to the protection of minorities relies on human rights provisions stipulating equal rights and non-discrimination together with special measures when necessary to overcome discrimination. The responsibility for minority protection lies primary with their State of residence. If the home State fails to fulfill its responsibility, whether it is unable or unwilling, the subsidiary responsibility shifts to the international community as a whole, not to the kin-State in particular. ${ }^{9}$ This discussion, therefore, explores the implementation of R2P, also in relation to the involvement of kin-States. The article examines how the protection of national minorities can be strengthened to prevent violent conflicts. The discussion also offers concrete suggestions on how kin-States can contribute to the protection of minorities beyond their borders in a way that does not provoke bilateral or regional tensions.

\section{The Responsibility to Protect Minorities}

The concept of R2P was endorsed by world leaders at the UN General Assembly in 2005. The subsequent World Summit Outcome Document affirmed that every sovereign government has a responsibility to protect its citizens and those within its jurisdiction from genocide, war crimes, and crimes against humanity. ${ }^{10}$ ) As a matter of fact, R2P is a restatement of binding obligations of States to protect their citizens from mass atrocity crimes, and it seeks to establish the collective responsibility of the international community to prevent such crimes. ${ }^{11}$ ) R2P is about taking effective action at the earliest possible stage to protect populations at risk. ${ }^{12}$ ) These obligations are particularly relevant to minorities who, more often than not, are the victims of such atrocities. ${ }^{13}$ ) The concept of R2P is more than a mere substitute for humanitarian intervention. Rather, the R2P norm is cast in three core pillars: first, an affirmation of the primary and continuing obligation of a State to protect its population from genocide, war crimes and crimes against humanity, as well as incitement thereof; second, a commitment by the international community to assist States in meeting these obligations; and third, acceptance by UN Member States of their responsibility to respond in a timely and decisive manner through the UN Security Council if national authorities are manifestly failing to protect their populations from these mass atrocity crimes.
In addition, the African Union (AU) has incorporated the right to intervene in a Member State as enshrined in Article 4(h) of its Constitutive Act of 2000. This was against the background of the failure of the international community to act decisively in preventing the 1994 genocide in Rwanda, the conclusion of the liberation struggles in Southern Africa with the independence of Namibia in 1990 (the outbreak of conflicts involving immense human suffering in the Great Lakes region, the Democratic Republic of the Congo (DRC) and the Mano River Basin region of West Africa, and the determination to deter the illegal seizure of power in African countries that contributed to the adoption by the AU of a security culture of indifference. ${ }^{14}$ ) It was within the new peace and security architecture of the AU that the norm of a responsibility to protect was embedded. Thus, by 2005, when R2P was adopted by the UN General Assembly a normative basis had been set for the congruence between R2P and Article 4(h).

This applies in respect of the fact that Article 4(h) has the same thresholds for intervention as R2P, although Article 4(h) does not use the innocuous term "ethnic cleansing". These thresholds are not only serious international crimes subject to universal jurisdiction but also crimes that invariably involve a government's action against its own citizens. The notable differences between the formulation of R2P and Article 4(h) are that a) the implementation of R2P is "through the Security Council" whereas the AU Act is silent on the authorization of the UN Security Council; b) R2P can be triggered when a target State is "manifestly unable or unwilling" to protect its citizens, whereas the AU can intervene with or without the consent of the target member State; and c) Article $4(\mathrm{~h})$ is a legal obligation while R2P is more of a political commitment.

Like Article 4(h) of the AU Constitutive Act, the primary goal of R2P is the prevention of genocide, war crimes and crimes against humanity. These atrocities can occur in both peace time and during external or internal conflicts, regardless of the type of government or level of development. Local, national, regional and international actors must be able to recognize factors that can indicate the risk of Article 4(h) and R2P crimes. To this end, the Analysis Framework, developed by the UN

<http://www.venice.coe.int/webforms/documents/CDL-INF(2001)019 e.aspx> (accessed 15 September 2014).

9) Olena and Kharkiv, "The Responsibility to Protect Minorities" note 2 above.

10) United Nations, The World Summit Outcome Document, Sixtieth Session, UN Doc. A/60/L.1/2005, 15 September 2005, paras. 138-139.

11) Dan Kuwali, "The African Union and the Challenges of Implementing the Responsibility to Protect", The Nordic African Institute, Policy Notes, 2009/4, p. 1.

12) Gareth Evans, The Responsibility to Protect: Ending Mass Atrocities Once and For All, Washington DC: Brooking Institution, 2008.

13) Nicholas Turner and Nanako Otsuki, "The Responsibility to Protect Minorities and the Problem of the Kin-State", Policy Brief No. 2, 2010, United Nations University, p. 1.

14) Kuwali, "The African Union and the Challenges of Implementing the "Responsibility to Protect", note 11 above, p. 1. 
Office on Genocide Prevention and the Responsibility to Protect (then the Office of the Special Adviser on the Prevention of Genocide), has developed eight factors that can determine whether there may be a risk of genocide in a country situation. These factors include, inter alia, discrimination, the incitement to violence against $\mathrm{mi}$ nority communities and the presence of illegal arms. ${ }^{15}$ ) Thus, in modern international law, the protection of minority rights is clearly the responsibility of the State in which they reside. States may have an interest in 'kin' living abroad, but no legal right of intervention. However, if the home-State fails to protect a minority group or groups, the international community, with the kin-State as part thereof, has the responsibility to protect populations at risk of mass atrocity crimes. The R2P and Article 4(h) norms are particularly relevant to the protection of vulnerable communities and provide guidance on the protection of kin minorities. ${ }^{16}$ ) The theory of R2P reaffirms the primacy of the home-State responsibility to protect populations within its boundaries in numerous international human rights instruments. If a State fails to fulfill this responsibility, whether it is unwilling or unable to do so, the subsidiary responsibility lies with the international community as a whole-and not the kin-State. ${ }^{17}$ ) States, therefore, have a dual responsibility where the first layer is the promotion and protection of the rights of minorities under their jurisdiction, and secondly to act as responsible members of the international community with respect to minorities under the jurisdiction of other States.

\section{The Protection of Minorities in International Law}

Most, if not all, countries in the world include persons belonging to national or ethnic, religious and linguistic minorities, enriching the diversity of their societies. Al too often, minorities face multiple forms of discrimination resulting in marginalization and exclusion from the wider population. Contemporary examples of extreme marginalization of minorities include the persecution of Christian minorities in some countries of the Middle East, the massacre of the African population in the Darfur Region of the Sudan and the violence against the Muslim minorities in the Central African Republic and Burma/Myanmar. Thus, minority protection is clearly of prime concern for the maintenance of international peace and security. ${ }^{18}$ ) There has been substantial progress by the international community in protecting persons belonging to national minorities, with standards adopted and monitoring mechanisms created through multilateral instruments. In these instruments, the primary responsibility to protect minorities consistently rests on the State having jurisdiction of the minorities in question. These standards and mechanisms are crucia to the maintenance of international peace and security, in particular conflict prevention. ${ }^{19}$ )

The 1948 UN Convention on the Prevention and Punishment of the Crime of Genocide (the Genocide Convention) was the first UN treaty to protect minorities, designed to protect them from the greatest threat to their existence. ${ }^{20}$ ) The UN Declaration on the Rights of Persons Belonging to National or Ethnic, Religious and Linguistic Minorities sets basic standards and offers guidance to States in adopting appropriate legislative and other measures to secure the rights of persons belonging to minorities. It states not only that minorities should not be targets of discrimination and marginalization but that ethnic, cultural, linguistic and religious diversity within a country should actually be encouraged and safeguarded. Now that the standard has been articulated, the next step is implementation. ${ }^{21}$ ) A UN Special Rapporteur on Minority Issues and an Expert Forum are gradually reviewing the national implementation of the Declaration and addressing issues its implementation will raise. Standard-setting initiatives at the regional level for the protection of minorities include two Council of Europe treaties, the Framework Convention for the Protection of National Minorities and the European Charter for Regional or Minority Languages, ${ }^{22}$ ) and the Organization for Security and Co-operation in Europe (OSCE) has adopted a series of texts relating to the role of minority rights in enhancing peace and security. ${ }^{23}$ )

Minority rights, for ethnic, religious or linguistic minorities, are an integral part of international human rights law. Minority rights constitute a legal framework designed to ensure that a specific group which is vulnerable, disadvantaged or in a marginalized position in society is able to achieve equal rights and receive protection from discrimination. To protect minority rights, countries

15) International Coalition for the Responsibility to Protect (ICRtoP), "The Responsibility to Protect Toolkit", available at: <http://responsibilitytoprotect.org/ICRtoP\%20Toolkit\%20on\%20the\%20Responsibility\% 20 to\%20Protect\%20high\%20res.pdf> (accessed 11 September 2014).

16) Turner and Otsuki, "The Responsibility to Protect Minorities and the Problem of the Kin-State", note 13 above, p. 3.

17) As above, p. 6. See also Asbjørn Eide, "The Non-Inclusion of Minority Rights: Resolution 217C (III), in Gudmundur Alfredsson and Asbjørn Eide (eds), The Universal Declaration of Human Rights: A Common Standard of Achievement, The Hague: Martnus Nijhoff Publishers, 1999.

18) Rolf Ekéus, OSCE High Commissioner on National Minorities, Organization for Security and Co-operation in Europe (OSCE), 26 October, 2001 The Hague, available at: <http://www.osce.org/hcnm/53936>(accessed 2 September 2014).

19) Ekéus, as above.

20) The United Nations (UN) instruments quoted in this article are all available at: <www.ohchr.org>; and also at: <www.un.org>(accessed 29 September 2014).

21) The Bahá'í International Community "Protection of Minorities", Statement to the 55th Session of the UN Commission on Human Rights under item 16 of the provisional agenda: Report of the Sub-Commission on Prevention of Discrimination and Protection of Minorities. Circulated at UN Document \# E/CN.4/1999/NGO/14, available at : <http:// statements.bahai.org/99-0107.htm> (accessed 7 September 2014).

22) Council of Europe, "Report on the Preferential Treatment of National Minorities by their Kin-State", adopted by the Venice Commission at its 48th Plenary Meeting, Venice, 19-20 October 2001, available at: <http://www.venice.coe.int/webforms/documents/CDL-INF(2001)019. e.aspx> (accessed 15 September 2014).

23) For instruments and description of activities, see Council of Europe available at: $<$ www.osce.org $>$ and also $<$ www.osce.org/hcnm $>$ (accessed 29 September 2014). 


\section{europa ethnica}

should adopt specific laws and set up commissions or ombudsman institutions. Generally, States through their commitments under treaty law, with minority participation, can influence the human rights implementation and monitoring procedures and work toward securing equal rights.

\section{The Propensity of Kin-States to Protect Minorities beyond their Borders}

Minority communities are often divided by arbitrary boundaries, cutting across groups with social, cultural and linguistic ties. It is a basic principle of international law that the State can act only within its jurisdiction which extends to its territory and citizenry. Although a State may have an interest in persons of the same ethnicity as its majority population but living abroad, this does not entitle or imply, in any way, a right under international law to exercise jurisdiction over these persons. At the same time, persons belonging to a national minority may maintain contacts across frontiers with citizens of other States with whom they share common ethnic, cultural, linguistic, religious or national origins. History shows that when States take unilateral steps on the basis of national kinship to protect national minorities living outside of their jurisdiction, it often leads to tensions and frictions and sometimes violent conflicts. These conflicts and refugees and asylum seekers may also spill over borders. ${ }^{24}$ )

National minorities have a right to protect and promote their identity, and it is the obligation of the state in which they live to defend that right. International norms affirm the rights of persons belonging to minority groups to establish peaceful contacts across borders with those of a common identity or heritage. But the strengthening of bonds between a kin-State and a neighboring minority risks creating or exacerbating tensions with their State of residence, resulting in a deterioration of bilateral relations. When the interest of the kin-State extends to cross-border interference and even attempts to take unilateral action on the basis of kinship to protect national minorities in third States, the likelihood of the situation degenerating into conflict is high. ${ }^{25}$ ) Consequently, two specific related fears overshadow such tensions: irredentist claims by the kin-State advocating annexation of the territory of another State; and secessionist claims from the minority themselves. ${ }^{26}$ )

History shows that the intervention of a so-called 'kinState' or 'motherland' to defend a threatened minority in a third State can increase rather than defuse conflict. ${ }^{27}$ ) Instead of helping find a solution, the kin-State exacerbates the problem. For example, Hitler invoked the concept of Schutzmacht as an ethnically based "right" of Nazi Germany to protect "its" kin in Poland and Czechoslovakia; India and Pakistan have fought wars in Kashmir in defence of their respective kin; Wars in the Balkans demonstrated what happens, both when minority protection fails and when kinship ties lead to inter-state conflict; Russia's relations with Russophones in its 'near abroad' highlight the potential for tensions; Hungary's attempts to strengthen ties with Hungarians abroad also highlight the potential for tensions; Kosovo's future will hinge on the relationship between Kosovo's Serbian community and its links with Serbia; and failure to protect minorities has led to atrocities in Rwanda, the Central African Republic, the Darfur region of Sudan in Africa and tensions in the Middle East. ${ }^{28}$ )

The State in which minority populations reside has the responsibility to protect minority rights, but if it fails to do so, the subsidiary responsibility shifts to the international community as a whole. ${ }^{29}$ ) A kin-State has no special responsibility and no right to protect minority groups abroad, beyond its responsibility as any other State in and as part of the international community. There is a clear need to ensure that the interest of the kin-State in protecting minorities abroad is pursued through constructive international engagement rather than unilateral interference. The kin-State's interest can be utilized as means to stimulate efforts to improve the general level of minority protection. Kin-State support should be offered only with the full cooperation and consent of the home-State in which the minority resides, to avoid escalating tensions. International and regional organizations must also strengthen the tools and political will to implement timely and decisive collective responses when States are manifestly failing to protect minorities.

\section{Towards Responsible Protection of Minorities}

In his 2009 report on implementing R2P, the UN Secretary-General emphasized that R2P encompasses the responsibility to prevent atrocities from occurring in the first place, so that intervention is not required. ${ }^{30}$ ) Given the role of discrimination and ethnic conflict in atrocity crimes, implementing the responsibility to prevent requires effective protection of minority rights. If minorities are adequately protected, this avoids the exploitation of minority issues, either by radicals in the minority community or by neighboring States which may even use violence to seek the world's attention. Below are some of the strategies for enhancing the protection of minorities by the international community, including the kin-State.

24) Ekéus, note 18 above.

25) As above.

26) Olena and Kharkiv, "The Responsibility to Protect Minorities" note 2 above.

27) As above.

28) As above. See also Frans Viljoen, International Human Rights Law in Africa, Oxford: Oxford University Press, 2012, pp. 222-223.

29) Turner and Otsuki, "The Responsibility to Protect Minorities and the Problem of the Kin-State", note 13 above, p. 4 . See also Olena and Kharkiv, "The Responsibility to Protect Minorities" note 2 above.

30) Turner and Otsuki, "The Responsibility to Protect Minorities and the Problem of the Kin-State", note 13 above, p. 3.

31) The Global Responsibility to Protect, “Iraq", available at: http://www. globalr2p.org/regions/iraq (accessed 13 September 2014). 
Upholding the Responsibility to Protect by Home Countries

It should be remembered that the primary responsibility to protect always rests with the home-State. It is only when that State is unable or unwilling to adequately protect its population that the international community including kin-States would be inclined to intervene. ${ }^{31}$ The home government must be able to uphold its responsibility to protect the whole population of the country, regardless of ethnicity or religion. Home governments must end institutionalized discrimination against all minorities within their borders. It must also hold accountable all those who commit abuses, including inciting ethnic and religious violence and hate speech. It is also necessary for home governments to facilitate the safe voluntary return of internally displaced persons (IDPs) and refugees to their communities. ${ }^{32}$ ) The home government must allow unhindered humanitarian access to those affected by violence.

\section{Political Leadership}

To protect minorities, political leaders must work to address issues of regional autonomy and perceptions of sectarian discrimination. Convening dialogues with minority representatives and allowing and facilitating minority participation in public life are essential components of such leadership. Politicians should refrain from incendiary sectarian speech and work towards national reconciliation, including equal treatment and representation for all communities. ${ }^{33}$ )

\section{Constructive Engagement by Kin-States}

While there is need to recognize the interest of the kin-State in protecting related minorities abroad, such interest should be pursued through constructive international engagement rather than unilateral interference. In this way, the kin-State's interest can be utilized as a means to stimulate efforts to improve the general level of minority protection in both states. To avoid escalating tensions, kin-States support should only be offered with the full cooperation and consent of the home-State in which the minority resides. Bilateral treaties and intergovernmental commissions between the States involved can be effective means to facilitate such constructive engagement by the kin-State; providing a legitimate means for active involvement of the kin-State enables improvements in minority protection while alleviating concerns and suspicions on both sides. ${ }^{34}$ ) Kin-States may also be directly affected if a State is failing to protect its minorities through, for example, strong public opinion advocating intervention to protect the kin abroad or through an influx of refugees. Kin-States including neighboring States may offer advice or assistance to improve the protection of related minorities abroad. Neighboring countries are also crucial as they usually offer protection to asylum seekers. ${ }^{35}$ )

\section{Wider Minority Participation in Public Institutions}

Wider minority participation in public institutions should be encouraged. For example, Hungary's agreement with Serbia and Montenegro ensures minority representation in public services, including the national police. The State is clearly the most appropriate actor to implement these measures, as part of its primary obligation to protect its entire population and to ensure equal rights. But R2P's second "pillar" also requires the international community to assist States in building their capacity to implement the responsibility to prevent. A kin-State can play a role in a multilateral context, in its capacity as an integral member of the international community. ${ }^{36}$ )

\section{Promotion of Equal Rights}

Indeed, States should not only ensure that policy and practice guarantee the minimum of minority rights, but they should promote full and effective equal rights between minority and majority persons. ${ }^{37}$ ) Ruling groups (whether they be the majority or a minority) have a special responsibility, for the sake of justice and peace, to bring about the social and political adjustments which will enable the other components of their society to exercise, to the fullest extent possible, their common and fundamental rights. Those groups not in power ought to respond positively to genuine efforts made toward them and to recognize, accept and fulfill their responsibilities toward society at large. As issues arise, both majorities and minorities must view them in the context of an increasingly interdependent world, where the advantage of the part is best served by ensuring the advantage of the whole, and where the whole cannot flourish when parts are oppressed or deprived. ${ }^{38}$ )

\section{Eradicating Conditions that Disenfranchise Minorities}

Governments need to take the lead by proving and acting on their determination to accord to minorities the same rights accorded to other citizens. This they can do by identifying the conditions that tend to disenfranchise certain

32) The Global Center for the Responsibility to Protect, "Burma/Myanmar", available at: <http://www.globalr2p.org/regions/burma_myanmar> (accessed 15 August 2014).

33) As above.

34) Turner and Otsuki, "The Responsibility to Protect Minorities and the Problem of the Kin-State", note 13 above, p. 7.

35) As above, p. 2.

36) The potential constructive role for kin-States in resolving sensitive and volatile minority issues was evident in the successful resolution of a long-running disagreement between Italy and Austria over the status of the German-speaking minority in the South Tyrol region of northern Italy. Following World War II, Austria pursued its kin interest through bilateral negotiations with UN oversight, leading to the eventual implebilateral negotiations with UN oversight, leading to the eventual imple-
mentation of a treaty giving greater autonomy to the region. See Turner and Otsuki, "The Responsibility to Protect Minorities and the Problem of the Kin-State", note 13 above, p. 1.

37) Ekéus, note 18 above.

38) The Bahá'í International Community, "Protection of Minorities", note 21 above. 


\section{europa ethnica}

minorities and by enacting and implementing legislation that will address those conditions. Such legislation is an important step, but legislation alone will never, in and of itself, end discrimination against minorities. Attitudes and prejudice must change. Groups must learn to view one another in fundamentally different ways. They must see each other as partners, as co-workers, as worthy of respect and just treatment. Majorities must rid themselves of the assumption of entitlement, and minorities must eventually break free of the helplessness and suspicion induced by prolonged discrimination. ${ }^{39}$ )

\section{Ending a Culture of Impunity by Prosecution of Perpetrators of Discrimination}

Attacks by belligerents pose a grave threat to civilians. There is need to end a pervasive culture of impunity which usually provides a fertile ground for commission of further mass atrocity crimes. ${ }^{40}$ ) Legislation can actually facilitate changes in attitude by placing legal sanctions on behavior that was once considered acceptable. By motivating people to change the way they behave, legislation can stimulate an examination of the beliefs underlying the old behavior and consideration of the principles that support the new behavior. ${ }^{41}$ )

\section{Promotion of Multicultural and Inter-Cultural Education}

Unity is not uniformity. In order to move toward a world characterized by unity in diversity, children must be taught to recognize diversity as a source of enrichment, not as a threat. The UN monitoring bodies on minority rights have rightfully focused on the promotion of multicultural and inter-cultural education. An understanding of cultural diversity as the varied expression of our common humanity is one of the keys to the peaceful and lasting resolution of conflicts involving minorities. School curricula should aim at rendering obsolete old animosities, based upon ethnic, linguistic and religious differences, by providing instruction about the various cultures present in each country in a way that highlights common aspirations and characteristics.

When children are taught to recognize fundamental human qualities in a wide variety of cultural forms, they will be able to regard each culture as enriching society as a whole. They will also be much less vulnerable to manipulation by those who would pit one group against another for political reasons. ${ }^{42}$ ) States must support minority groups in expressing and preserving their identities, while promoting integration and equality before the law to strengthen social cohesion and prevent discrimination. Language and history are particularly important-from the integration of minority languages and minority cultures into educational curricula and media content, to the general involvement of minority language speakers in public life. ${ }^{43}$ )

\section{Bilateral Agreements}

Bilateral treaties can serve as a useful function in respect of national minorities in the sense that they offer a vehicle through which States can legitimately share information and concerns, pursue interests and ideas, and further protect particular minorities on the basis of the consent of the State in whose jurisdiction the minority falls. However, the bilateral approach should not undercut the fundamental principles laid down in multilateral instruments. In addition, States should be careful not to create such privileges for particular groups which could have discriminatory and disintegrative effects in the States where they live. ${ }^{44}$ )

Bilateral agreements on minority issues can serve to build confidence for both sides. For the kin-State, they provide a means through which to legally and legitimately improve protection of kin minorities in the home-State. Perhaps more importantly, for the home-State they relieve concerns of interference by the kin-State. Indeed, they can expressly stipulate that the parties have no territorial claims on each other-a particular concern where there are fears of secessionist movements. ${ }^{45}$ ) To be effective, agreements must use specific language which addresses the practical concerns of the minority community, rather than vague references to 'protecting identity'. The implementation of minority-specific bilateral agreements - or of minority provisions within general treaties on friendly bilateral relations - must also be monitored to avoid further disputes, through mechanisms such as joint intergovernmental commissions. ${ }^{46}$ )

\section{Standard-Setting by the International Community}

For the wider international community, efforts to improve minority protection by building domestic State capacity are the primary means to implement R2P in this context. Global and regional organizations must also strengthen the tools and political will to implement timely and decisive collective responses when States are manifestly failing to protect their citizens. ${ }^{47}$ ) In Burma/

\section{9) As above.}

40) The Global Center for the Responsibility to Protect, "Burma/Myanmar", note 32 above.

41) The Bahá'í International Community, "Protection of Minorities", note 21 above.

\section{2) As above.}

43) Turner and Otsuki, "The Responsibility to Protect Minorities and the Problem of the Kin-State", note 13 above, p. 4.

44) Ekéus, note 18 above.

45) Most bilateral agreements affirm the right of individuals to express, preserve and promote ethnic, cultural, linguistic and religious identity individually and as a member of a group. Culture features prominently in bilateral treaties concerning national minorities, including provisions on the rights to express, preserve and promote the ethnic, cultural, linguistic and religious identity of persons belonging to national minorities See Turner and Otsuki, "The Responsibility to Protect Minorities and the Problem of the Kin-State", note 13 above, p. 6.

46) Turner and Otsuki, "The Responsibility to Protect Minorities and the Problem of the Kin-State", note 13 above, p. 6.

47) Olena and Kharkiv, "The Responsibility to Protect Minorities", note 2 above. 
Myanmar, for instance, the international community must urge the government to prioritize the development of a comprehensive plan to engage all ethnic and religious minorities in an inclusive reconciliation process. The international community should only lift sanctions following a demonstrable improvement in the welfare of ethnic and religious minorities. ${ }^{48}$ )

\section{Early Warning and Standard-Setting}

Under the auspices of the United Nations and regional organizations, a range of multilateral treaties and declarations setting forth standards for minority protection have been adopted and commitments undertaken by States. But regional organizations may be particularly well placed to implement the responsibility to prevent. As the early warning and conflict prevention capacity of the United Nations is relatively limited, regional arrangements for conflict prevention should be encouraged. ${ }^{49}$ )

\section{Conclusion}

The issue of protection of minorities has long been on the international agenda owing to the prevalence of tensions and violent conflicts throughout the world. Considering that most countries have minorities of some sort within their borders and that discrimination against them is widespread, such problems should not come as a surprise and governments are slowly realizing that the potential for instability is indeed a common one. The lessons of the past have underlined the necessity of respect for the rights of persons belonging to national minorities freely to express, preserve and develop their cultural, linguistic and/or religious identity free of any attempts at assimilation. While maintaining their identity, a minority should be integrated in harmony with others within a State as part of society at large.$^{50}$ ) This is fundamental to international peace, security and prosperity. Achieving effective participation of minorities and ending their exclusion requires embracing diversity through the promotion and implementation of international human rights law. A kin-State with strong ethnic, cultural, religious or linguistic links to a minority population abroad, may be wellplaced to assist in its protection through international efforts. But unilateral interference by kin-States will likely raise tensions with home-States, thereby endangering international peace and security. If a State neglects its primary responsibility to protect minorities under its jurisdiction, a subsidiary responsibility lies with the international community as a whole, not the kin-State alone. Kin-State interest in minorities abroad must thus be pursued through constructive engagement, rather than unilateral interference.

Global and regional organizations must build the domestic capacity of States, while at the same time strengthening the tools and political will to deliver timely collective responses when States fail in their responsibilities. Bilateral and multilateral mechanisms alike can counter nationalist rhetoric and policies by emphasizing that a diverse, well integrated society is in the interest of both the majority and minorities. ${ }^{51}$ ) Bilateral and multilateral mechanisms for minority protection should focus on specific, practical difficulties and solutions, such as minority languages and representation in public institutions. If the dialogue is dominated by vague, emotive questions of 'national identity', minority issues will be vulnerable to exploitation. At the same time, nationalist rhetoric must be countered by emphasizing that a diverse, well-integrated society is in the interests of both the majority and minorities, and that the existence of minority groups enriches the cultural values of the respective countries. ${ }^{52}$ )

For the wider international community, efforts to improve minority protection by building domestic State capacity are the primary means to implement R2P in the context of protecting the fundamental rights of minorities. Effectively mobilizing international efforts requires accurate risk assessment and early warning for minority-related conflicts. The intergovernmental organizations must build and strengthen the third 'pillar' of R2P. If the international community, both the human rights and security mechanisms, fails in this responsibility, the danger of kin-States proceeding unilaterally and taking issues of protection of kin-minorities into their own hands will increase. ${ }^{53}$ )

The responsibility of all actors extends beyond when the threat to populations is no longer imminent, and includes holding perpetrators accountable, establishing mechanisms for rebuilding and reconciliation, restoring the peace and preventing the recurrence of violence. Protecting populations from R2P crimes and violations requires strengthening the prevention capacities and mobilizing the political will of States and global and regional organizations to respond early when threats of R2P crimes and violations arise. Upstream prevention involves measures that governments can employ in their countries, such as developing institutions and policies and strengthening sectors, that reduce the risk that mass atrocities will occur. Downstream prevention involves responses to imminent threats of mass atrocities. These measures may be economic, political, humanitarian or military, and can be undertaken by actors in the international community, including civil society, individual governments, regional and sub-regional arrangements, and UN bodies. ${ }^{54}$ )

48) The Global Center for the Responsibility to Protect, "Burma/Myanmar", <http://www.globalr2p.org/regions/burma_myanmar> (accessed 4 August 2014).

49) Turner and Otsuki, "The Responsibility to Protect Minorities and the Problem of the Kin-State", note 13 above, p. 5.

50) Ekéus, note 18 above.

51) Turner and Otsuki, "The Responsibility to Protect Minorities and the Problem of the Kin-State", note 13 above, p. 1.

52) As above, p. 6.

53) Olena and Kharkiv, "The Responsibility to Protect Minorities", note 2 above.

54) ICRtoP, ‘The Responsibility to Protect Toolkit”, note 15 above. 


\title{
Indigenous rights at the United Nations: Their impact on inter- national human rights standards
}

\author{
Alexandra Xanthaki
}

\section{Introduction}

Indigenous rights have been described as a revolution for the United Nations. Indeed, the adoption of the United Nations Declaration on the Rights of Indigenous Peoples (UNDRIP) in 2007 has been widely recognized as a major success for indigenous peoples' rights. Finalized after more than 20 years deliberations, the Declaration has been adopted with objections by New Zealand, Canada, USA and Australia. Since 2007, all four states that had opposed it have stated a change of position. The instrument recognizes a very wide range of rights to indigenous peoples, including self-determination; separate legal, judicial and other systems; intellectual property rights; land rights; and right to natural resources. Several authors have emphasized the need for implementation of the Declaration in order to consolidate its standards (Stavenhagen, Daes), and some authors argue that many parts of it are already considered customary international law (Anaya, Wiessner, Lenzerini).

Although the Declaration has been the major development in this area, other UN developments on indigenous rights should not be underestimated: the establishment of on-going mechanisms in the United Nations specifically on the situation and concerns of indigenous peoples, such as the Permanent Forum on Indigenous Issues and the Expert Mechanism on the Rights of Indigenous Peoples; the interpretation of general standards in a manner favorable to indigenous claims by international bodies; and the development of strong regional standards on indigenous rights have been major successes of the transnational indigenous movement. Without overlooking differences - and at times tensions - among indigenous groups on claims and tactics, their common strategies have bore fruits.

This paper goes beyond the obvious impact that the Declaration has had on the rights of indigenous peoples and examines its wider impact on the standards of international human rights law. In specific, the paper argues that indigenous rights have contributed to pushing forward the standards of international human rights law. In this respect, the paper sides with other authors who have noted the transformative effect of indigenous rights for international law and international organizations, as they [indigenous rights] have changed 'the very ground rules of the Westphalian order that had privileged state actors over non-state actors, and privileged state sovereignty over principles of justice and democratic inclusion'. ${ }^{1}$ ) In specific, by adopting new, far-reaching provisions on indigenous rights, the UN Declaration on the Rights of Indigenous Peoples (UNDRIP) has also pushed forward the general standards of human rights, which could have wide ramifications for the rights of other sub-national groups. Kymlicka disagrees with the view that the Declaration has made a difference on other groups. ${ }^{2}$ ) The paper sets out to prove that potentially, the recognition of indigenous rights can make a difference. It focuses on five areas in order to highlight the 'added value' of the Declaration with respect to the previous contours of international law: the right to self-determination, collective rights, cultural rights, land rights and participation and consultation rights.

\section{Contribution of the UNDRIP to general human rights} standards:

\section{The question of self-determination}

The full and unqualified recognition of the indigenous right to self-determination in the final text of the UNDRIP is definitely a huge success of the transnational indigenous movement. Article 3 of the Declaration is a repetition of common article 1.1. of both International Covenants, only with the addition of 'indigenous' before the term 'peoples'. This is the first explicit recognition in any international law instrument of the right to selfdetermination to specific sub-national groups and as such, it cannot be over-estimated. Until the adoption of the UNDRIP, there was little doubt among international lawyers that self-determination as an unqualified right was only recognized to whole populations of states. Although Crawford emphasized early on that the right to self-determination should not be seen as a right recognized to states, as only human beings have human rights, ${ }^{3}$ ) nevertheless the right continued to be attributed to whole populations of states until very recently.

1) Will Kymlicka, 'Beyond the Indigenous/Minority Dilemma?' in Stephen Allen and Alexandra Xanthaki (eds), Reflections on the UN Declaration on the Rights of Indigenous Peoples, (Hart, 2011), p. 183-288. Kymlicka the Rights of Indigenous Peoples, (Hart, 2011), p. 183-288. Kymlicka
brings in examples of authors that believe this including Muehlbach 2003; Passy 1999; Feldman 2002; Smith 2008; Morgan 2004; Falk 1988, 1995.

2) Ibid.

3) J Crawford, 'Peoples or Governments' in Crawford (eds). The rights of Peoples (Oxford, Clarendon Press, 1992) p. 59. 
Although the language of international instruments on self-determination could be interpreted to include some sub-national groups, the explicit references to the principle of territorial integrity were put forward as evidence that the instruments only referred to whole populations of states. UN Resolution $1541^{4}$ ) recognized the right of self-determination to non-self-governing territories and defined such territories in a way that could include some sub-national groups, i.e. 'a territory which is geographically separate and is distinct ethnically and/or culturally from the country administering it' and placed arbitrarily 'in a position or status of subordination' to the administering state. The Belgian thesis supported the application of self-determination beyond colonialism ${ }^{5}$ ) and was supportive of indigenous claims for self-determination on the basis that their treatment was comparable to that of colonised territories, ${ }^{6}$ ) but the Blue thesis, which viewed self-determination within the parameters of overseas colonies, prevailed. ${ }^{7}$ ) The 1970 Declaration on Principles of International Law concerning Friendly Relations and Co-operation among States in accordance with the Charter of the United Nations ${ }^{8}$ ) expanded the beneficiaries of self-determination to 'peoples under colonial or racist regimes or other forms of alien domination' (emphasis added), ${ }^{9}$ ) whereas the 1975 Final Act of the Conference on Security and Co-operation in Europe ${ }^{10}$ ) (Helsinki Declaration) expanded the understanding of 'peoples' to 'peoples' living in independent states. However, in all the instruments the principle of territorial integrity was also included. The (1993) Vienna Declaration and Program of Action ${ }^{11}$ ) affirmed the right of peoples to take legitimate action, in accordance with the UN Charter to realize their right of self-determination, ${ }^{12}$ ) but again included the usual restrictions of territorial integrity and political unity.

Judicial bodies around the world also supported the view for a long time that the unqualified right to self-determination was recognized only to whole states: The prevalence of territorial integrity over self-determination within the context of Africa was noted by the International Court of Justice in the Frontier Dispute case between Burkina Faso and Mali, where the Court affirmed that 'the maintenance of the territorial status quo in Africa is often seen as the wisest course $(. . .)^{\prime 13}$ ) At the end of the 1980s, the Inter-American Commission on Human Rights affirmed in the Miskito Indians case ${ }^{14}$ ) that international law did not recognize the right of self-determination to any ethnic group. ${ }^{15}$ ) The question of whether indigenous peoples are 'peoples' for the purposes of article 1 was raised before the Human Rights Committee twice, but both communications were declared inadmissible on other grounds. ${ }^{16}$ ) In 2000 when the issue was raised again in the Apirana Mahuika case, the Committee repeated that the examination of the right to self-determination is not within its mandate, but noted that 'the provisions of article 1 may be relevant in the interpretation of other rights protected by the Covenant, in particular article $27^{\prime} .^{17}$ ) Therefore, the Court again refused to see article 1 as relevant to indigenous peoples. Academics also agreed that if self-determination is viewed as secession, then sub-national groups have no such right. ${ }^{18}$ )

The whole construction of seeing the full right of selfdetermination recognized only to whole populations of states gradually fell during the elaboration of the

4) Resolution 1541 (XV) on Principles Which Should Guide Members in Determining whether or not an Obligation Exists to Transmit the Information Called for under Article $73 \mathrm{e}$ of the Charter of 15 December 1960, UN GAOR, 15th Session, Supplement No. 16 (A/4684), p. 29.

5) The Belgian delegate stated in the Fourth Committee that 'similar problems' to the overseas colonies '[e]xisted wherever there are underdeveloped ethnic groups [...] in America as well as in Asia or Africa.' He observed that 'more than half the sixty members of the United Nations had backward indigenous peoples in their territories', although only eight had admitted to be administering states under chapter eleven. See 7 UNGAO C.4 (253d meeting), UN Doc. A/2361 (1952), 22-23.

6) The Belgian view could be interpreted as a means to protect Belgium's interests in Belgian Congo. It was a response to the criticisms by the developing states about the exploitation of the natural resources of the colonies. Belgium at the time was exploiting Congo's natural resources, colonies. Belgium at the time was exploiting Congo's natural resources,
mainly the copper of Katanga. If Belgium enabled Katanga to secede from a possibly independent Congo, then, they could still exploit the copper of Katanga. See P. Thornberry, 'Self-Determination, Minorities, Human Rights: A Review of International Instruments' (1989) 38 International and Comparative Law Quarterly 867-889 at 874 .

7) See UN GAOR, Official Record of the General Assembly, 7th session, 4th Committee, 55.

8) GA Res. 2625, UN GAOR, 25th Sess., Supp. 28 (1971), 9 ILM 1292. 9) Paragraph 7 of the chapter on 'The principle of equal rights and selfdetermination of peoples'. Other similar declarations followed, such as UNGA resolution 3103 (XXVIII), adopted in December the 12th, 1973, entitled 'Basic Principles of the Legal Status of the Combatants struggling Against Colonial and Alien Domination and Racist Regimes'.

10) Conference on Security and Co-operation, Final Act, August 1, 1975, 14 ILM 1292.

11) The Vienna Declaration and Program of Action was the outcome of the (1993) Second World Conference on Human Rights, where 180 States participated and hundreds of non-governmental organisations attended. The Vienna Declaration and Programme of Action have been published by the United Nations Department of Public Information, Doc. DPI/1394-39399, August 1993.

12) The Declaration recognized: the right of peoples to take any legitimate action, in accordance with the Charter of the United Nations, to realise their alienable right of self-determination. The World Conference on Human Rights considers the denial of self-determination as a violation of human rights and underlines the importance of the effective lation of human rights
realisation of this right.

13) Frontier Dispute case (Burkina Faso v. Mali), Judgement, ICJ Reports (1986) at 567. For an analysis of the judgments of the International Court of Justice on self-determination see A. Cassese, 'The International Court of Justice and the Right of Peoples to Self-Determination' in V. Lowe and M. Fitzmaurice (eds.), Fifty years of the International Court of Justice, M. Fitzmaurice (eds.), Fifty years of the International Court of Justice,
Essays in Honour of Sir Robert Jennings (Cambridge: Grotius Publications, 1996), pp. 351-363 and J. Crawford, 'The General Assembly, the International Court and Self-determination' in Lowe, Fitzmaurice, International Court of Justice, pp. 585- 605.

14) Inter-American Commission on Human Rights, Report on the Situation of Human Rights of a Segment of the Nicaraguan Population of Miskito Origin, OAS Docs. OEA/Ser.L/V/II.62, doc.10 and rev 3 (1983) and OEA/Ser.L/V/II.62, doc. 26 (1984). See H. Hannum, 'The Protection of Indigenous Rights in the Inter-American System' in D. J. Harris and S. Livingstone (eds.), The Inter-American System of Human Rights (Oxford: Clarendon Press, 1998), pp. 323-343 at pp. 328-331.

15) Ibid, pp. 78-79.

16) $A D$ v. Canada (1989) 79 I.L.R., 261 and Kitok v. Sweden, CCPR/C/33/D/197/1985. For an analysis of the first case, see M. E. Turpel, 'Indigenous Peoples' Rights to Political Participation and SelfDetermination' (1992) 25 Cornell International Law Journal 579-602. 17) Communication No. 547/1993: New Zealand. 15/11/2000. CCPR/ C/70/D/547/1993 (Jurisprudence) UN Doc CCPR/C/70/D/541/1993 Human Rights Committee, paragraph 9.2.

18) Crawford on Quebec. 


\section{europa ethnica}

UNDRIP. It was assumed that the unqualified right to self-determination meant secession and since secession violated territorial integrity, no sub-national group could enjoy it. During the elaboration of the UNDRIP, several States repeatedly stated that sub-national groups were not to be regarded as beneficiaries of an unqualified right to self-determination; hence, indigenous peoples could not be perceived as 'peoples' for the purposes of article 1 of the International Covenants. ${ }^{19}$ ) However, gradually a shift in States language was evident; just before the adoption of the Declaration, the discussion was focused on the content of the indigenous right to self-determination, implying a consensus on the right of indigenous peoples regarding the internal aspect of self-determination.

The final text of the Declaration recognizes to indigenous peoples the full and unqualified right of self-determination (art. 3), while at the same time focuses the exercise of the right to self-government and autonomy (art. 4) and repeats the usual caveat of territorial integrity (art. 46.1). In this manner the UNDRIP makes clear that indigenous peoples have exactly the same right to self-determination as any other 'peoples' in the world. The exercise of this right will depend on how this right will be defined and on the obstacle of territorial integrity, as with all other 'peoples'. In this way, the UNDRIP opens the path for a 'looser' recognition of the right to self-determination that will potentially include other 'peoples' who are subnational nations and pushes forward the standards of international law.

What about the right to secede? By using the same language as Art. 1.1 of the International Covennats, the UNDRIP makes clear that the same rules that apply for any other 'peoples' will also apply to 'indigenous peoples'. And the rules that apply can see secession in 'extremely exceptional circumstances', ${ }^{20}$ ) in cases of oppression and non-representation in government, ${ }^{21}$ ) if 'the people' occupies a distinct territory and is persistently and egregiously denied political and social equality as well as the opportunity to retain its cultural identity. ${ }^{22}$ ) Heraclides has gathered the specific conditions under which a remedial right to secession can be recognized: there must be a systematic exploitation or discrimination against a sizeable, well-defined minority; the minority must be a distinct self-defined community or society, compactly inhabiting a region which overwhelmingly supports separatism; secession must be a realistic prospect of conflict resolution and peace within and between the new and the old state as a result of the envisaged selfrule or partition; and the central government must have rejected all compromise solutions. ${ }^{23}$ ) The possibility of remedial secession for any 'peoples' has been confirmed by the ICJ in the Crime of Genocide case, ${ }^{24}$ ) by the ECtHR Loizidou v. Turkey case ${ }^{25}$ ) the African Commission on Human and Peoples' Rights Katangese Peoples Congress v. Zaire, ${ }^{26}$ ) and the Supreme Court of Canada. ${ }^{27}$ ) The Kosovo case in the ICJ was hoped to clarify the beneficiaries for remedial secession, but unfortunately did not do so. ${ }^{28}$ )
What is certain is that the recognition that indigenous peoples, ie sub-national groups, have the right to selfdetermination breaks the previous prevailing view on the beneficiaries of self-determination. Weller has rightly joined the voices of those who are looking for new approaches "to the settlement of self-determination conflicts that break away from that [old] restrictive paradigm." ${ }^{29}$ ) The indigenous paradigm has certainly contributed to this.

\section{The scope of self-determination}

The UNDRIP did not only change who the beneficiaries of the right to self-determination are; it also changed what the scope of the right is. Viewing self-determination as including but not being restricted to secession has been a key element that allowed the expansion of its beneficiaries to include indigenous peoples. The equation of self-determination with secession is a trap in which often States and commentators fall. ${ }^{30}$ ) Earlier instruments did

19) For example, see statements of: the USA in the Report of Commission Working Group, UN Doc. E/CN.4/2000/84 (1999), para. 49; ARGENTINA in Consideration of a Draft United Nations Declaration on the Rights of Indigenous peoples, Information received by the Governments, UN Doc. E/CN.4/1995/WG.15/2 (1995) ARGENTINA, para. 6; FRANCE in Report of Commis (1996), para. 329; MAROCCO in Consideration of a Draft United Nations Declaration on the Rights of Indigenous peoples, Information received by the Governments, UN Doc. E/CN.4/1995/WG.15/2/Add.1, MOROCCO, para. 3; JAPAN in Report of the Commission Working Group UN Doc. E/ CN.4/1997/102 (1996), para. 340.

20) 'Report by Malcolm N. Shaw: “Re: Order in Council P.C. 1996-1497 of 30 September 1996"' in Bayevsky, Quebec and Lessons Learned, pp. $125-150$ at p. 138

21) T. D. Musgrave, Self-Determination and National Minorities (Oxford: Clarendon Press, 1997), pp. 188-192.

22) T. M. Franck, 'Postmodern Tribalism and the Right to Secede' in Brölmann, Lefeber, Zieck, Peoples and Minorities, pp. 3-27 at pp. 13-14; also, Franck Report in Quebec and Lesons Learned, p. 79.

23) A. Heraclides, 'Secession, Self-Determination and Non-Intervention: In Quest of a Normative Symbiosis' (1992) 45 Journal of International Affairs 399-420 at 400-411.

24) Case concerning Application of the Convention on the Prevention and Punishment of the Crime of Genocide, (Bosnia-Herzegovina v. Yugoslavia) [1996] ICJ Rep., General List No. 91 (1996). G. Gilbert, Autonomy and Minority Groups- A Legal Right in International Law?, Paper Prepared for the Seventh Session of the Working Group on Minorities of the Sub-Commission on the Promotion and Protection of Human Rights, UN Doc. E/CN.4/Sub.2/AC.5/2001/CRP.5 (2001), p. 20.

25) Loizidou v. Turkey (Merits), European Court on Human Rights, 18 December 1996 (1997) 18 Human Rights Law Journal 50 at 59 (concurring opinion of Judge Wildhaber, joined by Judge Ryssdal).

26) Communication 75/92, reproduced in (1996) 3 International Human Rights Reports at p. 136. For an analysis of the case, see 0. C. Okafor, 'Entitlement, process and legitimacy in the emergent law of secession' (2002) 9 International Journal on Minority and Group Rights 41-70; also see Thornberry, Indigenous Peoples, pp. 256-258.

27) Supreme Court of Canada, Reference re Secession of Quebec Judgement of 20 August 1998, reproduced in Bayevsky, Quebec and Lessons Learned, pp. 455-505 at p. 504.

28) ICJ Report, Accordance with International Law of the Unilateral Declaration of Independence in Respect of Kosovo, Advisory Opinion, para. 122.

29) M Weller, Escaping the self-determination trap (Leiden: Martinus Nijhoff, 2008), p. 11.

30) Babafemi Akinrinade, 'Book Review of Marc Weller, Escaping The Self-Determination Trap, ISBN: 13: 978-9004174887, Leiden: Martinus Nijhoff Publishers, 2008, 224 pp' in 12 (2010) International Community Law Review 261-263 at 262. 
not help: the Declaration against Colonialism, Resolution $1541,{ }^{31}$ ) the 1965 Declaration on the Inadmissibility of Intervention in the Domestic Affairs of States and the Protection of Their Independence and Sovereignty ${ }^{32}$ ) and the 1970 Declaration on Principles of International Law concerning Friendly Relations and Co-operation among States $^{33}$ ) all viewed self-determination as independence. This focus started changing already in 1975, when the Final Act of the Conference on Security and Cooperation in Europe (Helsinki Declaration) ${ }^{34}$ ) projected self-determination as an ongoing process that prescribed that not only should the peoples be free of any external interference, they should also be free of any internal interference. This new meaning, which further strengthened the link between self-determination and popular sovereignty, corresponded to the international reality of the Cold War and Western states' interest in emphasizing the principles of democracy, free elections and participation. When in the early 90 s the former Soviet Union and Yugoslavia collapsed, the new emerging states brought again claims for independence to the surface. However, this time it was different from the 60s: it was clearly understood that self-determination was not only about independence. Several documents focussed on participatory structures within the state, ${ }^{35}$ ) democracy by monitoring elections, ${ }^{36}$ ) referred to the possibility of autonomous regimes ${ }^{37}$ ) and stressed the link between the on-going process of self-determination and human rights guarantees..$^{38}$ )

By the time the transnational indigenous movement focused on self-determination in the 90s, the right had collapsed into specific applications and voices were multiplying urging for defining the right merely by its applications, i.e. as independence or any other externa status, democratic governance and participation in the political life of the state. ${ }^{39}$ ) The indigenous debate, driven by a very powerful transnational indigenous movement, managed to push for a more holistic understanding of the right.

For indigenous peoples, self-determination has always been about their right to determine their destiny. Daes has described the indigenous understanding of selfdetermination as 'the right to negotiate freely [indigenous] peoples' political status and representation in the States in which they live', a kind of 'belated Statebuilding', through which indigenous peoples are able to join with all the other peoples that make up the State on mutually agreed and just terms, after many years of isolation and exclusion. ${ }^{40}$ ) This understanding of selfdetermination is much wider than merely the addition of secession, independence, political participation and self-governance. Indigenous peoples' vision of selfdetermination as explained throughout the elaboration of the UNDRIP between 1982 and 2007 is about respect for the peoples identities, control of all aspects of their lives and inclusion in the decisions that affect them. For indigenous peoples, 'self-determination includes, inter-alia, the right and the power of indigenous to negotiate with States on an equal basis the standards and mechanisms that will govern relationships between them. ${ }^{41}$ ) And the UNDRIP reflects this indigenous understanding of the right, and in this way, contributes to the evolution of the meaning of self-determination. Koivurova disagrees and reads the text of UNDRIP as allowing only for internal self-determination. He notes: 'Article 4 [of UNDRIP] gives more force to the argument that the right to autonomy and self-governance are the ways the indigenous peoples self-determination can be realised' ${ }^{42}$ ) Indeed, the UNDRIP includes the principle of territorial integrity and does focus on internal self-

31) Three years earlier, in 1962, the General Assembly had established a Special Committee on the Situation with regards to the Implementation of the Declaration on the Granting of Independence to Colonial Countries and Peoples, charged mainly with reporting and making recommendaand Peoples, charged manly with reporting and making recomme lution 1541, UN GAOR, 15th Session, Supplement no 16, at 29, UN Doc. A/4651 (1960). 32) Resolution 2131 (XX) of 21 December 1965.

33) GA Res. 2526, UN GAOR, 25th Sess., Supp. 28 (1971), 9 ILM 1292. Also see the 1965 Declaration on the Inadmissibility of Intervention in the Domestic Affairs of States and the Protection of Their Independence and Sovereignty, which was in the same spirit.

34) Final Act, Conference on Security and Co-operation, August 1, 1975 , 14 ILM 1292.

35) For example, UN Doc.A/47/49 (1993), Declaration on the Rights of Persons Belonging to National or Ethnic, Religious or Linguistic Minorities, 1992, United Nations General Assembly Res.47/135, Annex, 47 UNGAOR Supp.(No.49) p. 210; U.N. Doc. E/CN.4/1995/60 (1995), Resolution 1995/60 on "ways and means of overcoming obstacles to the establishment of a democratic society and requirements for the maintenance of democracy', UN Commission on Human Rights ESCOR Supp. (No. 4) p. 183, preamble; section VI of the (1990) Document of Supp. (No. 4) p. 183, preamble; section VI of the (1990) Document of
the Copenhagen Meeting of the Conference on the Human Dimension of the CSCE, (1990) 11 HRL 232.

36) For example, the (1990) CSCE Document of the Copenhagen Meeting of the Conference on the Human Dimension, paras 6- I.8; the (1991) Geneva CSCE Meeting of Experts on National Minorities, http://www.osce. org/docs/english/1973-1990/other_experts/gene91e.htm (accessed 2 August 2004), section III; CSCE Paris Summit, the Charter of Paris for a New Europe (1990), http://www.osce.org/docs/english/1990-1999/ summits/paris90e.htm (accessed on 2 August 2004). Also, the 1991 summits/paris90e.htm (accessed on 2 August 2004). Also, the 1991
General Assembly OAS Resolution stated that the principles of the OAS General Assembly OAS Resolution stated that the principles of the OAS
Charter 'require the political representation of [member] States to be based on effective exercise of representative democracy'. Resolution AG/RES 1080, 21-0/91 adopted on 5 June 1991.

37) For example, Recommendation 1201 on 'an additional protocol on the rights of national minorities to the European Convention on Human Rights', Council of Europe Parliamentary Assembly Text adopted on 1 February 1993 (22nd Sitting), article 11; the (1990) CSCE Document of the Copenhagen Meeting of the Conference on the Human Dimension of the CSCE, para. 35; the (1991) Geneva CSCE Meeting of Experts on National Minorities, section 4.

38) For example, UN Doc. CCPR/C/21/Add.3, General Comment 12(21), Human Rights Committee, GAOR, 39th Sess., Supp.40, Annex $\mathrm{VI}$; also, Doc. DPI/1394-39399, Vienna Declaration and Program of Action (1993).

39) G Alfredsson, 'The right of self-determination and indigenous peoples' in S Tomuschat (ed), Modern Law of Self-determination (Dordrecht, Nihjoff, 1993) pp. 41-54.

40) See E.-I. Daes, Explanatory Note concerning the draft Declaration on the Rights of Indigenous Peoples, UN Doc. E/CN.4/Sub.2/1993/26/ Add1 (1993), para. 26.

41) The Effect of Racism and Racial Discrimination on the Social and Economic relations between Indigenous peoples and States, Geneva: United Nations, 1989, UN Doc. HR/PUB/89/5, 8, para (viii).

42) Timo Koivurova, 'Sovereign States and Self-Determining Peoples: Carving Out a Place for Transnational Indigenous Peoples in a World of Sovereign States' International Community Law Review 12 (2010) $191-212$ at 202. 


\section{europa ethnica}

determination. At the same time though, it is clear that internal self-governance (art. 4) is only an aspect of the wider right recognized in article 3 . The text includes a plethora of applications of self-determination that go beyond its internal aspect: the right 'to maintain and develop contacts, relations and co-operation' across borders (article 36.1); recognizes treaties as 'the basis for a strengthened partnership between indigenous peoples and States' (15th preambular paragraph); and to have the agreements and arrangements made with States enforced (art. 37). These agreements are matters of 'international concern and responsibility'. ${ }^{43}$ )

In addition to the external aspects mentioned above, the UNDRIP also explains more how internal self-determination will materialize: it has many scattered references to indigenous rights to participate in the decision-making processes of the State; rights to control the exercise of State legislative and administrative functions concerning indigenous affairs; and the recognition by the State of indigenous political and legal institutions and acceptance of the legitimacy of indigenous laws, traditions and customs. The provisions go into detail regarding the modalities of self-determination and by doing this, the declaration strengthens the understanding of selfdetermination but also evolves its scope. It recognizes for example, the right of indigenous peoples to maintain and strengthen their distinct political, legal, economic, social and cultural institutions (art. 5); the indigenous right to "participate in decision-making in matters which would affect their rights, through representatives chosen by themselves in accordance with their own procedures, as well as to maintain and develop their own indigenous decision-making institutions' (art. 18); and the right to consultation (Art. 19).

Control of indigenous peoples over their affairs also includes control over their lands. For indigenous peoples, land rights are an application of their right to selfdetermination and the declaration recognizes a variety of such rights. In this respect, the Declaration moves the understanding of self-determination beyond the traditional parameters of political power. Even more obvious is this in the case of cultural self-determination. ${ }^{44}$ ) The Declaration links cultural rights to self-determination. Article 5 refers to the right of indigenous peoples to maintain their cultural institutions. Article 34 UNDRIP establishes that indigenous peoples "have the right to promote, develop and maintain their institutional structures and their distinctive customs, spirituality, traditions, procedures, practices and, in the cases where they exist, juridical systems or customs, in accordance with international human rights standards".

Helen Quane argues that the links the Declaration creates between cultural rights, such as identity, on the one hand and self-determination or participatory rights on the other pushes the indivisibility and interdependence of human rights much further than believed. 'It is now possible for indigenous peoples' she notes 'to invoke participatory rights by virtue of the right to effective participation in public life, the right to respect for their identity, and the right to self-determination. In this respect, one can see the emergence of a certain interdependence and indivisibility in terms of the content of these different human rights'. ${ }^{45}$ ) So again, indigenous rights as recognized in UNDRIP contribute to strengthening the principles of international human rights law.

\section{The question of collective rights}

Another tangible contribution to the evolution of international law standards by the UNDRIP relates to collective rights. Collective rights have traditionally been opposed by liberal authors. One of the main arguments against collective rights relates to objections to recognizing any moral standing to groups; according to this line of thought, groups cannot be right holders because they have no morally significant interests. Jones notes that "it is simple nonsense - nonsense upon stilts - to suppose that, if we treat individual persons as the ultimate units of moral concern, that must prevent us from taking full account of the communal dimensions of their lives'. ${ }^{46}$ ) The UN debate on the DRIP has showed beyond any doubt that collective rights are indispensible for some people and in particular for indigenous nations. Their identities are intricately linked to their community more than any western liberal can understand. For them, refusing collective rights is like denying them their right to identity.

The argument that critics of collective rights offer that collective rights are essentially reducible to rights of the members of the group has also been discredited in the UNDRIP. ${ }^{47}$ ) Liberals have suggested that collective rights can be adequately protected, ${ }^{48}$ ) for example through the individual right to association. ${ }^{49}$ ) Indigenous peoples have confirmed that this is not always the case. Their connection to land for example, cannot be reflected in the individual right to property as understood previously in human rights. Also, providing them with a system of individual rights has failed to protect them from the main violations of their human rights, because these include violations of a collective nature, towards indigenous communities as a group.

\section{3) Thirteen paragraph of the draft Declaration.}

44) S. Wiessner, "Indigenous Sovereignty: A Reassessment in Light of the UN Declaration on the Rights of Indigenous Peoples" 41 (2008) Vanderbilt Journal of Transnational Law 1141 at 1176.

45) H. Quane, "A further dimension to the interdependence and indivisibility of human rights?: Recent developments concerning the rights of Indigenous Peoples" (2012) 25 Harvard Human Rights Journal 49-83 at 51.

46) P. Jones, 'Individuals, Communities and Human Rights' (2000) 26 Review of International Studies 199-215 at 215.

47) J. Donnelly, 'Human Rights' in J. Dryzek, B. Honig and A. Phillips (eds.), Oxford Handbook of Political Theory (Oxford University Press, 2006) forthcoming, published in http://www.du.edu/ jdonnell/papers/ oxford_handbook.pdf, accessed on 20 July 2005.

48) Y. Tamir, Liberal Nationalism (Princeton: Princeton University Press, 1993), pp. 45 and 53; also, Y. Tamir, 'Who do you trust?' (1997) 22 Boston Review at http://www.bostonreview.net/BR22.5/toc.html, accessed on 19 July 2005.

49) Kukathas, 'Are there any cultural rights?' 20 (1992) Political Theory 105. 
Another main argument of the critics of collective rights has been founded on positivism: France for example, has repeatedly stated that "collective rights did not exist in international human rights law, and therefore [France] had reservations with regard to those articles that aimed to establish collective rights'.$^{50}$ ) The adoption of the UNDRIP confirms that this is not true. Although there were other collective rights that were already recognized, after the adoption of the UNDRIP there can be no doubt that international law clearly recognizes collective rights. The recognition of collective rights in the UNDRIP is important for indigenous peoples, but can also prove of paramount importance to other sub-national groups. As it stands currently, the limited collective dimension of the Declaration on Minorities 'represents a via media between the rights of individuals and full collective rights'. ${ }^{51}$ ) If the recognition of collective rights is seen as a natural progression of standards of international law, then the Declaration paves the way for the recognition of collective rights to minority groups. Kymlicks disagrees: 'I see no evidence that the conceptual or procedural breakthroughs made by indigenous peoples are opening doors for minorities. On the contrary (...) the dramatic enhancement of the rights of indigenous peoples over the past 15 years has coincided with a period of stagnation, even retrenchment, in the international status of minorities, and with growing international hostility to many minority rights claims.' He is right. However, the door has opened and others can make use of the achievements that indigenous rights have made, even if such use has not been made successfully yet. The UNDRIP does clarify international law with respect to collective rights.

\section{Cultural rights}

Contrary to other international instruments, the UNDRIP unfolds the generic 'right to culture' into other rights included in several articles, including the right of indigenous peoples to their cultural traditions and customs; to manifestations of their cultures, spiritual and religious traditions; the right to their histories, languages and oral traditions and so forth. Therefore, even though the understanding of culture is broad and so is the scope of the cultural rights included in UNDRIP, the text specifically clarifies such a scope. It is the first instrument that recognizes aspects of the 'right to culture' in such detail; treats such aspects as human rights (rather than state rights) and links them to sub-national groups (rather than to whole populations of states). In this respect, the Declaration pushes forward the existing standards of international law in cultural rights.

Indeed, international law has been to a degree a mere observer to the mis-appropriation of indigenous artefacts, allowing states to treat indigenous exhibits as 'national' treasures and to make the decisions regarding their transfer and exhibition. ${ }^{52}$ ) The (1972) UNESCO Convention concerning the Protection of the World Cultural and Natural Heritage (World Heritage Convention), for example, only protects objects of outstanding or monumental value and does not give indigenous peoples any role in protecting their own heritage. The convention recognizes the states' 'duty of ensuring the identification, protection, conservation, presentation and transmission to future generations of the cultural and natural heritage' (Art. 4), but recognizes no right of any group to such heritage. The adoption of UNDRIP clearly changes the rule of the 1972 Convention: now, article 4 has to be interpreted in the light of article 11.1 UNDRIP as well as the right of indigenous peoples to free, prior and informed consent on matters that directly affect them. The states' duty to identify, protect, conserve and present indigenous tangible heritage found on their territory must coincide with the right of the indigenous peoples concerned to control the protection, conservation and presentation of such tangible indigenous heritage.

Similarly, the (1970) UNESCO Convention on the Means of Prohibiting and Preventing the Illicit Import, Export, and Transfer of Ownership of Cultural Property must be interpreted in a way consistent to UNDRIP. The Convention protects:

(a) Cultural property created by the individual or collective genius of nationals of the State concerned, and cultural property of importance to the State concerned created within the territory of that State by foreign nationals or stateless persons resident within such territory; (b) cultural property found within the national territory.

The 1995 UNDROIT Convention on Stolen or Illegally Exported Objects, created to compliment the 1970 Convention, recognizes the heritage of tribal and indigenous communities living in a Contracting State. However, the 1995 Convention puts the State where such heritage comes from in charge of such claim against another state and is of no use for heritage taken by the state without the consent of the indigenous community. The convention has to be interpreted in light of the UNDRIP's provisions that clearly put indigenous peoples in charge of their cultural heritage.

Indeed, the duality that prevails in instruments that view cultural heritage as belonging either to the state or to an individual ends after the adoption of the UNDRIP which explicitly recognizes the right of indigenous peoples to their cultural heritage found within the state territory and indigenous control over their cultural tangible heritage. The recognition that the UNDRIP now offers to indigenous peoples is important in turning them from

50) See Commission on Human Rights, Report of the working group established in accordance with Commission on Human Rights Resolution 1995/32, UN Doc. E/CN.4/1997/102, para. 108.

51) P Thornberry, 'The UN Declaration on the Rights of Persons Belonging to National or Ethnic, Religious and Linguistic Minorities: Background, Analysis, Observations and an Update' in A Philips and A Rosas (eds) Analysis, Observations and an Update' in A Philips and A Rosas (eds),
Universal Minority Rights (the Hague, Martinus Nijhoff, 1995), 13, 54. 52) A Xanthaki, Indigenous Rights and UN Standards: Self-determination, Culture, Land (CUP, 2010), 197-200. 


\section{europa ethnica}

passive participants in processes of alienation from their objects $^{53}$ ) to actively deciding the fate of their cultural objects. ${ }^{54}$ ) The UNDRIP is not alone in recognizing the right of a sub-national group to its cultural heritage. The recent Council of Europe Framework Convention on the Value of Cultural Heritage for Society recognizes the right 'alone or collectively'. Such instruments 'have opened new perspectives on social participation in heritage making,.$^{55}$ )

\section{Land rights}

Major has also been the contribution of the UNDRIP and indigenous rights to the elaboration of land rights. ${ }^{56}$ ) Land rights have very few and scattered references in international law beyond indigenous rights, even though there have been some initiatives asking for a recognition of land rights. ${ }^{57}$ ) Land rights and in particular nondiscrimination in land rights has been discussed only with respect to women's rights in CEDAW. ${ }^{58}$ ) The right to property has traditionally been seen as dealing with land issues, but even the recognition of this right has been turbulent. One should note that the International Covenants do not even recognize the right to property. ${ }^{59}$ ) In any case, the right to property has not been an adequate right to protect the right to acquire land, as it has mainly been seen as the right of the 'Ianded'. ${ }^{60}$ ) Also, it was developed as an individual right, rather than as right of communities striving to get (back) lands or use of land for their survival. Indigenous rights, especially through their interpretation by the Inter-American system of human rights protection, have strengthened the presence of land rights in the human rights scene and have clarified that land rights are human rights and can be collective rights; they have linked them to the right to life and the right to culture - just just the right to property - and must be actively protected by the state. The Inter-American Court of Human Rights (IACtHR) has firmly established in the Awas Tingni case, ${ }^{61}$ ) Yakye Axa v. Paraguay, ${ }^{62}$ ) Sawhoyamaxa v. Paraguay ${ }^{63}$ ) and Saramaka People $v$. Suriname ${ }^{64}$ ) that the right of indigenous peoples to collectively own their ancestral lands stems from Article 21 ACHR interpreted in the light of their special spiritual relationship to their lands. Article 25 UNDRIP also recognizes the special relationship of indigenous peoples with their land, while Article 26 UNDRIP recognizes their right to lands, territories and resources. The ILO Convention No. 169 also recognizes indigenous rights to ownership and possession over lands they have traditionally occupied and asks for measures to safeguard the rights of indigenous peoples. ${ }^{65}$ ) The jurisprudence of the African Commission on Human and Peoples' Rights, ${ }^{66}$ ) statements in support of indigenous land rights from the Human Rights Committee, ${ }^{67}$ ) the CERD, ${ }^{68}$ ) UN experts, ${ }^{69}$ ) UN Special Rapporteurs on indigenous peoples' related issues, ${ }^{70}$ ) opinions of the ILO adjudicatory bodies and, in many cases, domestic law have clarified and elaborated further collective land rights and have paved the way for other groups to claim their land rights under international law.
A recent development that indicates in particular that indigenous land rights carve the way for the recognition of land rights to more groups, is the draft Declaration on the Rights of Peasants ${ }^{71}$ ) which is currently being discussed at the UN level. It is even mentioned that the structure of the new instrument follows that of the UNDRIP. ${ }^{72}$ ) A discussion is currently ongoing as to the links between the draft Declaration on the rights of peasants and other rural people and the UNDRIP. ${ }^{73}$ )

53) J Clifford 'Museums as Contact Zones' in J Clifford, Travel and Translation in the Late Twentieth Century, (Cambridge, Massachusetts and London: Harvard University Press, 1997), 188.

54) T Lanauze, S Forbes and M Solomon, 'A practical approach to traditional knowledge and indigenous heritage management: A case-study of Moriori heritage management practice' in SM Subramanian and B Pisurati (eds), Traditional Knowledge in Policy and Practice (United Nations Press, 2010), 330.

55) G Dolff-Bonekamper, 'Cultural Heritage and Conflict: the view from Europe' 245- 246 (2010) Museum International 14, 14.

56) A Xanthaki, 'Indigenous rights under the light of energy exploitation' (2013) German Yearbook of International Law 105. +

57) P Plant, 'Land rights in human rights and development: introducing a new ICJ initiative' 51 (1993) International Commission of Jurists Review 10. O de Schutter, 'The green rush: the global race for farmland and the rights of land users' 52 (2011) Harvard International Law Journal 504.

58) CEDAW Art. 16 and CEDAW Committee General Comment No 21 on 'Equality in marriage and family relations'. Also see Protocol to the African Charter, Art. 15.

59) W Schabas, 'The omission of the right to property in the International Covenants' 4 (1991) Hague Yearbook of International Law' 135.

60) J Gilbert, 'Land Rights as Human Rights: The case of a specific right to land' (2013) 10 International Journal of Human Rights 115.

61) IACtHR, Tingni Community v. Nicaragua (note 52), para. 149.

62) Id., Yakye Axa Indiginous Community v. Paraquay, Merits, Reparations and Costs, Judgment of 17 June 2005, Series C No. 125, paras. 124,137

63) Id., Sawhoyamaxa Indigenous Community v. Paraguay, Merits, Reparations and Costs, Judgment of 29 March 2006, Series C No. 146 paras. 118-121.

64) Id., Saramaka People v. Suriname (note 53), paras. 87-96.

65) Ibid.

66) See, e.g., African Commission on Human and Peoples' Rights Endorois (note 60).

67) See especially Human Rights Committee, Communication No. 167/1984, Chief Bernard Ominayak and the Lubicon Lake Band v. Canada, 26 March 1990, UN Doc. CCPR/C/38/D/167/1984 (1990); see also Id., Concluding Observations on the United States of America, 15 September 2006, UN Doc. CCPR/C/USA/CO/3 (2006).

68) See CERD (note 32); see also CERD, Decision 1 (53) on Australia, GAOR, 53rd Sess., Suppl. 18, 18; id., Concluding Observations on Brazil, 28 April 2004, UN Doc. CERD/C/64/CO/2 (2004), paras. 15-16; id. Decision 1 (66): New Zealand Foreshore and Seabed Act 2004, 11 March 2005, UN Doc. CERD/C/66/NZL/Dec.1 (2005); and id., Decision 1 (69) on Suriname, 18 August 2006, UN Doc. CERD/C/Dec/Sur/3 (2006).

69) For example, see CHR, Report on the Expert Seminar on Indigenous Peoples' Permanent Sovereignty over Natural Resources and Their Relationship to Land, 5 May 2006, UN Doc. E/CN.4/Sub.2/AC.4/2006/3 (2006).

70) E.g. CHR, Report of the Special Rapporteur on the Situation of Human Rights and Fundamental Freedoms of Indigenous Peoples, Mission to Guatemala, 24 February 2003, UN Doc. E/CN.4/2003/90/Add.2 (2003). 71) Final study of the Human Rights Council Advisory Committee on the advancement of the rights of peasants and other people working in rural areas, UN Doc. A/HRC/19/75 of 24 February 2012.

72) Ibd, para. 72.

73) Report of the open-ended intergovernmental working group on a draft United Nations declaration on the rights of peasants and other people working in rural areas, UN Doc A/HRC/26/48 of 11 March 2014, para. 48. 


\section{Participation and consultation rights}

A further area where indigenous rights have made a great difference relates to rights of participation and consultation. The requirement of participation of $\mathrm{mi}-$ norities in decisions that affect them has already been recognized in international law. The UN Declaration on the Rights of Persons belonging to Ethnic or National, Religious and Linguistic Minorities refers specifically to effective participation. ${ }^{74}$ )

The indigenous rights instruments link participation with consultation and discuss in detail what this requirement of consultation means. ILO Convention No. $107^{75}$ ) requires in Article 5 that governments seek the collaboration of indigenous populations and their representatives. The ILO Committee of Experts on the Application of Conventions and Recommendations (CEACR) has insisted on the "involvement of indigenous leadership before development projects affecting their situation have been undertaken"76) and has clarified that consultation with indigenous peoples should not be carried out "only at [the] inception" of the project in question; ${ }^{77}$ ) that "tribals should be made partners in the large development projects," ${ }^{78}$ ) and indigenous representatives should participate in decision-making bodies. ${ }^{79}$ ) ILO Convention No. $169^{80}$ ) recognizes the right of indigenous peoples to be consulted "through appropriate procedures and in particular through their representative institutions, whenever consideration is being given to legislative or administrative measures which may affect them directly" and to freely participate at all levels of decision-making when policies and programmes affect them (art. 6). Article 6 (2) specifically requires that the consultations "shall be undertaken, in good faith and in a form appropriate to the circumstances, with the objective of achieving agreement or consent to the proposed measures" (emphasis added). This provision must be read together with Article 7 which recognizes in paragraph 1 the right to indigenous peoples to "participate in the formulation, implementation and evaluation of plans and programmes for national and regional development which may affect them directly." Indigenous peoples should "decide their own priorities for the process of development as it affects their lives, beliefs, institutions and spiritual well-being and the lands they occupy or otherwise use, and to exercise control, to the extent possible, over their own economic, social and cultural development" (Art. 7) The convention also requires indigenous peoples "to participate in the use, management and conservation" of the natural resources in their lands and to be consulted "with a view to ascertaining whether and to what degree their interests would be prejudiced, before undertaking or permitting any programmes for the exploration or exploitation of such resources pertaining to their lands." Principle 22 Rio Declaration on Environment and Development (Rio Declaration) ${ }^{81}$ ) also asks States to enable the effective participation of indigenous peoples in the achievement of sustainable development", whereas World Bank Operational Directive $4.10^{82}$ ) stipulates that the borrower, be- fore embarking into a project, must engage in a process of free, prior, and informed consultation with indigenous peoples that aims at "broad support for the project." ${ }^{83}$ ) The UN Declaration on the Rights of Indigenous Peoples has pushed for a shift from the principles of consultation and participation to that of the free, prior and informed consent of indigenous peoples in development projects. ${ }^{84}$ ) During the discussions of the UNDRIP, it became obvious that FPIC must be seen under the light of the indigenous right to self-determination. FPIC is included in seven articles of the UNDRIP. The question whether the UNDRIP recognizes an indigenous right to FPIC and in which circumstances is at the moment the focus of intense discussion. ${ }^{85}$ ) Suffice to note that many UN bodies have repeated that States have to respect such a right, ${ }^{86}$ )

74) UN Declaration on the Rights of Persons belonging to Ethnic or National, Religious and Linguistic Minorities, GA Res. 47/135 of 18 December 1992

75) ILO Convention (No. 107) Concerning the Protection and Integration of Indigenous and Other Tribal and Semi-Tribal Populations in Independent Countries, 26 June 1957, UNTS 328, 247.

76) ILO, Report of the Committee of Experts on the Application of Conventions and Recommendations, Individual Observation concerning Convention No. 107, Indigenous and Tribal Populations, Bangladesh, 2005, para. 11; and also Individual Observation concerning Convention No. 107, Indigenous and Tribal Populations, Bangladesh, 2002.

77) Id., Report of the Committee of Experts on the Application of Conventions and Recommendations, Individual Direct Request concerning Convention No. 107, Indigenous and Tribal Populations, Brazil, 1990, para. 13.

78) Id., Report of the Committee of Experts on the Application of Conventions and Recommendations, Individual Observation concerning Convention No. 107, Indigenous and Tribal Populations, India, 2003, para. 11

79) Id., Report of the Committee of Experts on the Application of Conventions and Recommendations, Individual Direct Request Concerning Convention 107 Indigenous and Tribal Populations, Panama, (1991), para. 7. 80) ILO Convention (No. 169) concerning Indigenous and Tribal Peoples in Independent Countries, 27 June 1989, UNTS 1650, 383.

81) Rio Declaration on Environment and Development, Report of the United Nations Conference on Environment and Development, 12 August 1992, UN Doc. A/CONF.151/26 (Vol. I) (1992), Annex 1.

82) World Bank, Operational Policy 4.10 on Indigenous Peoples (July 2005), available at: http://web.worldbank.org/WBSITE/EXTERNAL/ PROJECTS/EXTPOLICIES/EXTOPMANUAL/O,,contentMDK:20553653 $\sim$ menuPK:4564185 pagePK:64709096 piPK:64709108 theSite PK:502184,00.html (accessed on 20 February 2014).

83) World Bank Group Management Response, Striking a Better Balance - The World Bank and Extractive Industries: The Final Report of the Extractive Industries Review, 17 September 2004, available at: http://www-wds.worldbank.org/external/default/WDSContentServer/ WDSP/IB/2004/09/21/000160016_20040921111523/Rendered PDF/300010GLB.pdf (accessed on 20 February 2014).

84) Cathal Doyle/Jill Cariño, Making Free, Prior and Informed Consent a Reality: Indigenous Peoples and the Extractive Sector, May 2013, 7, available at: http://www.piplinks.org/system/files/Consortium+FPIC+report+ +May+2103+-+web+version.pdf (accessed on 20 February 2014).

85) For this discussion, see A Xanthaki, 'Indigenous Peoples Rights under the Light of Energy Exploitation' 56 (2013) Yearbook of German Law, 315. Also see

86) Human Rights Committee, Communication No. 1457/2006, Ángela Poma Poma v. Peru, 24 April 2006, UN Doc. CCPR/C/95/D/1457/2006 (2006); Office of the High Commissioner for Human Rights (OHCHR) Letter to Nepal, 13 March 2009, available at: http://www2.ohchr.org/ english/bodies/cerd/docs/early_warning/Nepal130309.pdf (accessed on 21 February 2014). See CERD, Concluding Observations on the Russian Federation, 20 August 2008, UN Doc. CERD/C/RUS/CO/19 
and regional bodies have also accepted such a right. ${ }^{87}$ ) Recently, UN Special Rapporteur on the Right to Food, Olivier de Schutter indicated that the right to free, prior and informed consent should not only be restricted to indigenous peoples. In his 2009 report, the Special Rapporteur laid down 11 principles regarding the acquisitions of large land areas by states (land grab). Among them, Principle 2 maintains that "transfer of land-use or ownership can only take place with the free, prior and informed consent of the local communities. This is particular relevant to indigenous communities [...]'. ${ }^{88}$ Therefore, the Special Rapporteur expanded the beneficiaries of land rights beyond indigenous peoples to local communities.

\section{Concluding remarks}

The recognition of indigenous rights has opened the door for expanding the scope of rights and their beneficiaries. The UNDRIP has clarified several rights, such as the right to culture, and has pushed forward the existing standards in some other rights, for example participation and consultation. An important obstacle to the expansion of these rights to other groups, such as minorities, is the idea that indigenous rights are a 'special case', 'an emerging exception' to the otherwise individual focus of human rights. ${ }^{89}$ ) If this view prevails, then each group that claims these newly expanded rights must also show that they are a special case. However, almost eight years after the adoption of the UNDRIP, we continuously experience the consolidation of indigenous rights, especially by the regional bodies, as well as the tentative discussion of these rights with respect to other groups, notably peasants and rural groups. With all the challenges and short-comings, indigenous rights can potentially have long-felt, transformative effects for other groups in the international arena.

(2008). CERD, Summary Record of the Fist Part (Public) of the 1901st Meeting, 26 September 2008, UN Doc. CERD/C/SR.1901 (2008). Committee on Economic, Social and Cultural Rights (CESCR), Genera Comment No. 21 on the Right of Everyone to Take Part in Cultural Life, 21 December 2012, UN Doc. E/C.12/GC/21 (2009), paras. 36-37 and Concluding Observations on Colombia, 21 May 2010, UN Doc. E/C 12/ COL/CO/5 (2010); id Cons and, 30 May 2012, UN Doc. E/C.12/NZL/CO/3 (2012) . Human Rights Council (HRC), Promotion and Protection of all Human Rights, Civil, Political, Economic, Social and Cultural Rights, Including the Right to Development, Report of the Special Rapporteur, 15 July 2009, UN Doc. A/HRC/12/34 (2009), para. 47. HRC, Report of the Expert Mechanism on the Rights of Indigenous Peoples, 8 January 2009, UN Doc. A/HRC/10/56 (2008), Proposal No. 2, para. 4. See also Permanent Forum on Indigenous Issues, Report No. 2, para. 4. See also Permanent Forum on Indigenous Issues, Report
of the International Workshop on Methodologies regarding Free, Prior and Informed Consent and Indigenous Peoples, 17 February 2005, UN Doc. E/C.19/2005/3 (2005). HRC, Report of the Special Rapporteur on the Right to Food, 21 July 2009, UN Doc. A/HRC/12/31 (2009), para. 21 (j). HRC, Report of the Special Rapporteur on adequate housing as a J). HRC. Repoft of the Special Rapporteur on adequate housing as component of the right to an adequate standard of living and on the right to non-discrimination in this context, Miloon Kothari, UN Doc. E/ CN.4/2006/41 (2006), para 56 (e). UN Independent Expert on Minority Issues, Statement on the conclusion of the official visit to Colombia, 1-12 February 2010, para. V, available at: http://www.ohchr.org/EN/ NewsEvents/Pages/DisplayNews.aspx?NewsID=9821\&LangID=E (accessed on 18 March 2014).

87) IACtHR, Saramaka People v. Suriname, Judgment of 28 November 2007, Preliminary Objections, Merits, Reparations, and Costs, Series C No. 172, 40, para. 134. African Commission on Human and Peoples' C No. 172, 40, para. 134. African Commission on Human and Peoples'
Rights, Communication 276/03, Centre for Minority Rights Development (Kenya) and Minority Rights Group International on behalf of Endorois Welfare Council/Kenya, Decision of 25 November 2009, para. 291, available at: http://www.achpr.org/files/sessions/46th/ comunications/276.03/achpr46_276_03 eng.pdf (accessed on 22 February 2014)

88) 0 de Schutter, Report of the UN Special Rapporteur on the Right to Food, 2009

89) Donnelly, above n 15.

\section{Voraussichtlicher Platz für Werbung $153 \times 96,0 \mathrm{~mm}$}




\title{
Minderheitenschutz und Gleichheitsgebot im Wahlrecht
}

\author{
Ulrike Haider-Quercia
}

\section{Einleitung}

Für die Demokratie ist das Prinzip der Gleichheit aller Beteiligten wesentlich. Im Wahlrecht bezieht sich dieses Prinzip zunächst auf die formale Gleichstellung der Bürger als Inhaber von Stimmrechten und auf die Gleichbehandlung aller Beteiligten im Rahmen des Wahlvorgangs, insbesondere die Gleichbehandlung der Stimmen aller Wahlbürger hinsichtlich ihres Zählwertes. Die Wahlrechtsgleichheit ist eine strikt formale, mathematische Gleichheit, die keine Wertungen zulässt.

Darüber hinaus kann aber auch bei der Gleichheit der Wahl die Forderung nach materieller Gleichheit in Form eines Differenzierungsgebotes gestellt werden. In der Minderheitenliteratur wird sehr oft der Ansatz vertreten, dass der Sonderstatus einer nationalen Minderheit auch Berücksichtigung bei der Ausgestaltung des „gleichen“ Wahlrechts erfordere. Die Anwendung der rein formalen Gleichheit im Wahlrecht bewirkt nämlich oftmals eine faktische Ungleichheit der Wettbewerbschancen für die zahlenmäßig und strukturell kleinen Minderheitenparteien.

Dennoch wird die besondere Berücksichtigung von Minderheitenparteien in den Wahlsystemen für nationale und regionale Parlamente nur relativ selten als integraler Bestandteil der gegenwärtigen Minderheitenschutzgarantien betrachtet ${ }^{1}$ ). Minderheitenrelevante Umgestaltungen der allgemeinen Vertretungsregeln und Wahlverfahren werfen in den meisten europäischen Rechtsordnungen nach wie vor sensible verfassungsrechtliche Fragen auf, insbesondere im Hinblick auf den Gleichheitssatz und das Repräsentationsprinzip.

Vor diesem Hintergrund werden im vorliegenden Beitrag all jene Instrumente untersucht, die eine eigene politische Vertretung nationaler Minderheiten begünstigen und gewährleisten. Besondere Beachtung findet dabei das Instrument der sogenannten Wahlrechtsprivilegierung - d.h. jener begünstigenden Derogationen aus den wahlrechtlichen Bestimmungen, die eine positive und gerechtfertigte Ausnahme aus dem formalen Gleichheitssatz und dem Prinzip "one man, one vote “vorsehen, die Vertretung von Minderheiten im Parlament aber auch politisch-demokratischen Dynamiken unterwerfen ${ }^{2}$ ).

\section{Minderheitenschutz und Wahlrechtsbegünsti- gungen im Völker- und Europarecht}

Auf der Ebene des Völkerrechts wurde die Problematik der Wahlrechtsgleichheit nationaler Minderheiten stets diskutiert, doch gibt es keine allgemeine Bestimmung für eine öffentlich-rechtliche Sonderstellung und eigene politische Vertretung für Minderheiten. Die zahlreichen Initiativen zur Schaffung völkerrechtlicher Standards mündeten letztlich nie in allgemein verbindliche Regeln für eine eigene Repräsentation der nationalen Minderheiten im Parlament des Angehörigenstaates.

Die Problematik der Wahlrechtsgleichheit von nationalen Minderheiten trat zum ersten Mal im Zuge der Abfassung der Minderheitenverträge im Völkerbundsystem in Erscheinung ${ }^{3}$ ). In den Verträgen von Sèvres mit der Türkei, Griechenland und Armenien (welche zwar unterzeichnet, niemals aber ratifiziert wurden) war eine ganz allgemein gehaltene Verpflichtung enthalten, bei der Ausarbeitung des Wahlrechtes die Existenz von nationalen Minderheiten in Betracht zu ziehen ${ }^{4}$ ). Der Vertrag von Sèvres mit der Türkei, welcher 1923 durch den Vertrag von Lausanne ersetzt wurde, hatte erstmals das Prinzip der verhältnismäßigen Vertretung nationaler Minderheiten festgelegt ${ }^{5}$ ).

Da eine formelle Gleichheit bei der Ausübung des Wahlrechts nicht gleichzeitig auch eine formelle Gleichheit bei der verhältnismäßigen Verteilung der Mandate bedeutet $^{6}$ ), hatte 1919 die internationale Konferenz

1) Vgl. Z.B. F. Benoît-Rhomer, La repésentation des minorités dans le Parlements d'Europe centrale et orientale und C. Casonato, Pluralismo etnico e rappresentanza politica: spunti per un'analisi comparata, in: Diritto pubblico comparato ed europeo, n. 2/1999, welcher die politischen Mitsprache- und Teilnahmerechte als Ausfluss einer neuen Generation von Minderheitenrechten deutet.

2) Zentrales Thema der vorliegenden Abhandlung sind die minderheitenfreundlichen Wahlrechtsgestaltungen. Es wird daher nicht auf die staatsorganisatorischen Lösungen eingegangen, wie Autonomiesysteme und Föderalstrukturen, welche ebenfalls die Teilhabe der Minderheiten an der Staatsgewalt sichern, ohne dass es einer speziellen Wahlrechtsgestaltung bedarf.

3) Die meisten Minderheitenschutzbestimmungen dieser Zeit zielten ganz allgemein auf die Gleichheit vor dem Gesetz ab und bezogen darin die Ausübung der bürgerlichen und politischen Rechte durch Andarin die Ausübung der bürgerlichen und politischen Rechte durch An-
gehörige von Minderheiten mit ein. Vgl. S. Furlani, Sulla rappresentanza parlamentare delle minoranze nazionali, in: Rivista trimestrale di diritto pubblico, 1956, S. 17

4) Vgl. Art. 7 Vertrag von Sèvres vom 10. August 1920.

5) Vgl. F. Benoît-Rhomer und H. Hardemann, The Representation of Minorities in the Parliaments of Central and Eastern Europe, in: International Journal on Group Rights, Nr. 2/1994, S. 94.

6) In der Zeit nach dem Ersten Weltkrieg wurde darüber diskutiert, dass eine rein formelle Gleichberechtigung bei der Stimmabgabe und bei der Ausübung des Wahlrechts nicht immer ausreichend ist, um auch eine effektive Gleichheit der Minderheiten in den gewählten Vertretungskörpern zu gewährleisten. Den politischen Entscheidungsträgern der damaligen Zeit war bewusst, dass, selbst wenn die einzelnen Staaten verpflichtet waren, ihren fremdsprachigen Staatsbürgern das Wahlrecht in gleicher Weise wie den Angehörigen der Mehrheitsbevölkerung zuzusichern, die 


\section{europa ethnica}

in Bern vorgeschlagen, gemeinsam mit den sonstigen Maßnahmen des Minderheitenschutzes auch die Einführung von Verhältniswahlrechtssystemen verbindlich vorzusehen. Dieser Vorschlag wurde allerdings vom Redaktionskomitee der Minderheitenschutzverträge nicht übernommen und fand daher keine völkerrechtliche Verankerung ${ }^{7}$ ). Allein die damalige Tschechoslowakei hatte sich freiwillig zu einer begünstigten Vertretung aller nationalen Minderheiten im Parlament durch die Vorsehung eines Verhältniswahlrechts verpflichtet ${ }^{8}$ ).

Nach dem Zweiten Weltkrieg wurden die Minderheitenfragen auf internationaler Ebene ganz generell im Rahmen der allgemeinen Grund- und Freiheitsrechte abgehandelt, und so fand auch der Themenkreis der parlamentarischen Vertretung von nationalen Minderheiten kaum politische Resonanz. Ausdruck des damals vorherrschenden Zugangs zum Minderheitenschutz ist der Internationale Pakt der bürgerlichen und politischen Rechte der Vereinten Nationen vom 16. November 1966, welcher den Angehörigen von nationalen Minderheiten das Recht auf Schutz und Förderung der eigenen Kultur Religion und Sprache einräumt (Art. 27) und gleichzeitig das Recht aller Individuen festlegt, direkt und durch eigene gewählte Vertreter an den Entscheidungen der öffentlichen Sphäre mitzuwirken (Art. 25).

Die Problematik der politischen Vertretung von Minderheiten trat zudem als Frage zwischenstaatlicher Beziehungen auf. Bedeutende Bespiele hierfür sind etwa die Minderheitenschutzsysteme, die zwischen Deutschland und Dänemark ${ }^{9}$ ) sowie zwischen Italien und Österreich auf diplomatischem Wege erarbeitet worden waren. Diese Schutzsysteme schlossen jeweils spezifische Regelungen für die Vertretung der Minderheit in den regionalen und nationalen Vertretungskörpern mit ein ${ }^{10}$ ). Auf gesamteuropäischer Ebene wurde das Thema der politischen Partizipation der nationalen Minderheiten in den 90er-Jahren aufgegriffen; ein erster Anhaltspunkt findet sich im Dokument der Konferenz von Kopenhagen über die menschliche Dimension vom 29. Juni 1990 der OSZE, in welchem das Recht von Angehörigen nationaler Minderheiten vorgesehen wird, ,wirksam an öffentlichen Angelegenheiten teilzunehmen, einschließlich der Mitwirkung in Angelegenheiten betreffend den Schutz und die Förderung der Identität solcher Minderheiten“"11).

Auf der Ebene der Vereinten Nationen kommt das wiedererwachte Interesse an einer minderheitenspezifischen Vertretung in der Erklärung der „Kommission für Personen, die ethnischen, nationalen, religiösen oder sprachlichen Minderheiten angehören" vom 18. Dezember 1992 zum Ausdruck. In diesem rechtlich nicht verbindlichen Dokument wird das Recht von Minderheitenangehörigen, effektiv an sie betreffenden und mit ihrer Identität verbundenen Entscheidungen mitzuwirken ${ }^{12}$ ), sowie das Recht, Vereinigungen zu gründen, garantiert ${ }^{13}$.

Der gegenwärtig bedeutsamste Hinweis für eine politische Vertretung der Minderheiten findet sich in der Rahmenkonvention des Europarates. Die parlamentarische Vertretung von Minderheiten wird nunmehr als
Teil des in Art. 15 der Rahmenkonvention verankerten Prinzips der Beteiligung an Angelegenheiten, die sie betreffen, betrachtet ${ }^{14}$ ). Begünstigungen im Wahlrecht für Minderheiten stellen daher eine der Optionen dar, den in der Rahmenkonvention verbrieften Minderheitenschutzstandard umzusetzen. Eine europarechtliche Verpflichtung zur Gestaltung einer parlamentarischen Vertretung von nationalen Minderheiten gibt es daher nicht. Die parlamentarische Vertretung von Minderheiten wird vielmehr ganz allgemein von dem Recht auf Beteiligung an Entscheidungen, die Minderheitenangelegenheiten betreffen, mitumfass ${ }^{15}$ ); in diesem Bereich

nationalen Minderheiten dennoch sehr oft keine eigene Vertretung in den gewählten Institutionen, insbesondere im Parlament, erlangen konnten. Dies ist bekanntlich in dem Umstand begründet, dass eine formelle Gleichheit bei der Ausübung des Wahlrechts nicht gleichzeitig auch eine formelle Gleichheit bei der verhältnismäßigen Verteilung der Mandate bedeutet. Vgl. S. Furlani, Sulla rappresentanza parlamentare delle minoranze nazionali, in: Rivista trimestrale di diritto pubblico, 1956, S. 18

7) Keinen Erfolg hatte der Vorschlag, welcher während der Ausarbeitung des Friedensvertrags mit Polen gemacht wurde, der auf eine verhältnismäßige Vertretung der Minderheiten in den Vertretungskörpern auf allen Ebenen der Staatsgewalt abzielte und die Errichtung von besonderen Wahlkreisen vorsah. Vgl. S. Furlani, Sulla rappresentanza parlamentare delle minoranze nazionali, in: Rivista trimestrale di diritto pubblico, 1956, S. 18.

8) Vgl. Punkt 2 der Note des damaligen Premierministers Edvard Benes vom 20. Mai 1919.

9) Zur Entwicklung des Minderheitenschutzes im Bereich der bilateralen Beziehungen zwischen Dänemark und Deutschland siehe A. Kühn, Privilegierung nationaler Minderheiten im Wahlrecht der BRD und Schleswig-Holsteins, Frankfurt, 1991.

10) Von zentraler Bedeutung waren besondere Vertretungsregeln zugunsten der dänischen Minderheit in den nachbarschaftlichen Beziehungen zwischen Deutschland und Dänemark im Laufe der 50erJahre. Die Entwicklung des heutigen Schutzsystems für die dänische Minderheit in Schleswig-Holstein basiert unter anderem auf zahlreichen Änderungen der Wahlgesetzgebung die eine eigene politische Vertretung der Minderheit sicherstellen sollte. Die Bemühungen dieser Jahre sind der Minderheit sicherstellen sollte. Die Bemühungen dieser Jahre sind
Ausdruck freiwilliger politischer Zugeständnisse in einem Klima positiver nachbarschaftlicher Beziehungen und gegenseitiger Interessen der Regierungen dieser beiden Staaten. Vgl. S. Furlani, Sulla rappresentanza parlamentare delle minoranze nazionali, in: Rivista trimestrale di diritto pubblico, 1956, S. 26

Die Entwicklung zwischen Österreich und Italien verlief ähnlich, und die politische Vertretung von Minderheiten war Teil der bilateralen Übereinkommen und Verträge in der Südtirolfrage. Besondere wahlrechtliche Vorschriften waren im sogenannten „Paket für Südtirol“ von 1969 enthalten, welches die Verpflichtungen des Gruber - De Gasperi Abkommens konkretisierte. Die Maßnahme Nr. 111 sieht vor, dass die eine Beteiligung der Vertreter der italienischen und deutschen Sprachgruppen Südtirols im Parlament verhältnismäßig zum jeweiligen Antei in der Bevölkerung gesichert wird. Vgl. O. Peterlini, Südtirols Vertretung am Faden Roms. Die Auswirkungen von Wahlsystemen von ethnischen Minderheiten am Beispiel Südtirols in Rom von 1921-2013, in: P. Hilpold (Hg.), Minderheitenschutz in Italien, Wien, 2009, S. 53ff.

11) Punkt IV, Absatz 35

12) Mitumfasst sind auch Fragen, die die Region betreffen, in welcher die Minderheit lebt.

13) Art. 2, Abs. 2-4. Der gegenständliche Artikel der Erklärung legt zudem fest, dass die Teilnahme an den öffentlichen Entscheidungen in vereinbarer Weise mit der nationalen Gesetzgebung zu erfolgen hat. Der zuvor unternommene Versuch einer Konvention zum Schutz Der zuvor unternommene Versuch eir her Minderheiten auf eine ihrer Größe entsprechende Vertretung im Parlament vorsah, hatte keinen Erfolg.

14) Vgl. M. Weller, Article 15, in: M. Weller (Hg.), The Rights of Minorities in Europe, A Commentary on the European Framework Convention for the Protection of National Minorities, Oxford, 2005.

15) Art. 15 Rahmenkonvention. 
wird den europäischen Staaten nach wie vor ein breiter Handlungsspielraum eingeräumt, und es geht viel allgemeiner und weitläufiger um eine effiziente Einbindung der Minderheiten in die sie betreffende Angelegenhei$\left.\operatorname{ten}^{16}\right)$ und nicht um eine politische Repräsentation im traditionellen $\operatorname{Sinn}{ }^{17}$ ).

\section{Die Wahlrechtsbegünstigungen in den inner- staatlichen Rechtsordnungen}

Aus dem kurzen Abriss über die historischen Entwicklungen des Minderheitenschutzes im Völker- und Europarecht ist ersichtlich, dass sich auf überstaatlicher Ebene nur wenige und eher unpräzise Anhaltspunkte für die Ausgestaltung einer adäquaten politischen Vertretung von nationalen Minderheiten finden. Besondere Mechanismen für eine eigene politische Vertretung von nationalen Minderheiten haben sich in erster Linie im innerstaatlichen Recht herausgebildet. Die europäischen Staaten haben in den letzten 50 Jahren ein reiches und sehr unterschiedliches Instrumentarium entwickelt, um ihren Minderheiten eine eigene Vertretung zu gewährleisten. Die Brandbreite reicht von der Zuerkennung des allgemeinen Wahlrechts ohne Unterscheidung des ethnischen Ursprungs bis hin zu garantierten Sitzen in den nationalen Vertretungskörpern, unabhängig von der tatsächlichen zahlenmäßigen Größe der Minderheit ${ }^{18}$ ).

\subsection{Die erste Stufe der Wahlrechtsgleichheit: die politischen Grundrechte}

Grundvoraussetzung für eine effektive Wahlrechtsgleichheit nationaler Minderheiten mit den allgemeinen politischen Parteien ist die Zuerkennung der politischen Staatsbürgerrechte, insbesondere das (aktive und passive) Wahlrecht sowie das Recht auf Gründung von Vereinigungen und politischer Parteien ${ }^{19}$ ).

Eine wesentliche Voraussetzung für die Gestaltung einer effektiven Wahlrechtsgleichheit der Minderheiten ist daher der Zugang der Minderheitenangehörigen zur Staatsbürgerschaft des Angehörigenstaates, mit welcher in fast allen europäischen Staaten das aktive und passive Wahlrecht verbunden sind. Beschränkungen beim Zugang zur Staatsbürgerschaft des Angehörigenstaates gegenüber Angehörigen von nationalen Minderheiten stellen in den europäischen Rechtsordnungen nunmehr eher die Ausnahme als die Regel dar $\left.{ }^{20}\right)$. Dennoch finden sich immer wieder vereinzelt Fälle, in welchen es Minderheitenvertretern erschwert oder sogar versagt ist das aktive oder passive Wahlrecht auszuüben ${ }^{21}$ ) und politische Parteien ethnischer oder religiöser Gesinnung zu gründen.

In den meisten europäischen Verfassungen wird ausdrücklich die Freiheit vorgesehen, Vereinigungen und politische Parteien zu gründen. Einige wenige Verfassungen sehen dennoch eine explizite Einschränkung für die Gründung von Parteien vor, die sich auf ethnische oder religiöse Elemente stützen; darin wird eine Gefahr für die Einheit und Demokratie des Staates gesehen ${ }^{22}$ ). Abgesehen von der mit solchen Bestimmungen verbun- denen Grundrechtsproblematik ist dennoch anzuführen, dass in diesen Fällen Parteien nur mit den in den Verfassungen angegebenen Gründen und Verfahren untersagt werden dürfen, nicht aber mit den Mitteln minderheitenausschließender Wahltechniken.

16) Interessant ist diesbezüglich der Vorschlag einer Minderheitencharta durch einige Abgeordneten des EU-Parlaments. In diesem Entwurf war das Recht auf eine politische Vertretung ausdrücklich vorgesehen. Vgl. G. Toggenburg, Minority Protection in a Supranational Context, in: G. Toggenburg (Hg.), Minority Protection in the Enlarged European Union: The Way Foreward, Budapest, 2004.

17) Besondere Verbreitung finden diesbezüglich Institutionen und Organismen, die beratende Funktionen in Minderheitenangelegenheiten ausüben.

18) Von einem formalrechtlichen Gesichtspunkt aus betrachtet ist es interessant, anzumerken, dass (im Unterschied zu den Sprachenrechten und Autonomiesystemen) die Bestimmungen für eine spezifische Minderheitenvertretung nur sporadisch auf der Ebene des Verfassungsrechts vorgesehen sind. In den meisten Fällen werden Garantien für eine politische Partizipation von Minderheiten in einfachen Gesetzen, vielfach in den spezifischen Minderheitengesetzen oder im Rahmen der allgemeinen Wahlgesetze, vorgesehen.

19) Vgl. C. Casonato, Pluralismo etnico e rappresentanza politica: spunti per un'analisi comparata, in: Diritto pubblico europeo e comparato n. 2/1999, S. 609 und F. Palermo und J. Woelk, Diritto costituzionale comparato, Padova, 2011, S. 109. Diese erste Ebene für die Ermöglichung der politischen Partizipation setzt einen nicht diskriminierenden Ansatz der Rechtsordnung voraus, in welcher die Wahlrechte in gleicher Weise für alle Mitglieder der Bevölkerung (bzw. Staatsbürger) garantiert weise fü

20) Die Problematik der Zuerkennung der politischen und zivilen Grundrechte an alle Mitglieder der Bevölkerung war im Zuge der Neugründung einiger baltischer Staaten sehr evident; damals wurde eine große Anzahl an Mitgliedern der russischen Minderheit in Ermangelung de Verleihung der Staatsbürgerschaft des Angehörigenstaates auch von der politischen Teilnahme gänzlich ausgeschlossen. Vgl. S. Bartole, Par politischen Teilnahme ganzlich ausgesch lossen. $\mathrm{vg}$ ( nuove democrazie dell'Europa centro-orientale, in: F. Lanchester (Hg.), La legislazione elettorale degli Stati dell'Europa centro orientale, Milano, 1995, S. 129.

21) Die Ausübung des Wahlrechtes wurde in einigen Fällen von bestimmten Voraussetzungen wie einer angemessenen Beherrschung der offiziellen Sprache des Staates abhängig gemacht. Dies war etwa in Lettland und Estland der Fall, deren Rechtsordnungen zwischen Staatsbürgerschaft und Nationalität unterscheiden und die für die Abgeordneten des Parlaments und die Kandidaten für die Wahl der höchsten politischen Funktionen bestimmte sprachliche Kenntnisse vorsahen. Vgl. F. Palermo/ J. Woelk, Diritto costituzionale comparato die gruppi e delle minoranze, Padova, 2011, S. 111. Beschränkungen beim Erwerb der Wahlrechte können ebenso auch Ausfluss eines bestimmten Minderheitenschutzsystems sein. So etwa in den italienischen Regionen mit Spezialstatut, wo bei einem Zuzug in das Siedlungsgebiet der französischen oder der deutschsprachigen Minderheit eine Mindestdauer des Wohnsitzes für deutschsprachigen Minderheit eine Mindestdauer des Wohnsitzes für
die Ausübung des aktiven Wahlrechts auf lokaler Ebene vorgesehen ist. die Ausübung des aktiven Wahlrechts auf lokaler Ebene vorgesehen ist.
Vgl. Art. 25, 2. Abs. des Spezialstatuts von Trentino-Südtirol. Ein ähnlicher Mechanismus wurde 2011 in der Provinz Trentino eingeführt, wo Voraussetzung für die Ausübung des aktiven und passiven Wahlrechts die Aufrechterhaltung eines Wohnsitzes in einer der Gemeinden der Provinz über mehr als ein Jahr ist.

22) So etwa Art. 11, 4 der bulgarischen Verfassung, welcher die Gründung ethnisch oder religiös inspirierter Parteien untersagt. Eine derartige Beschränkung besteht auch in Albanien, wo die Gründung politischer Parteien der Minderheiten aufgrund des Parteiengesetzes von 1991 nach wie vor nicht möglich ist, obwohl Art. 9 Abs. 1 der neuen Verfassung von 1998 die freie Errichtung von politischen Parteien gewährleistet. Vgl. C. Pan / B.S. Pfeil, Minderheitenrechte in Europa, Handbuch der europäischen Volksgruppen, Wien, 2006, S. 47. In Frankreich steht das Prinzip „une nation indivisible“ der Konzipierung von Minderheitendas Prinzip „une nation indivisible “ der Konzipierung von Minderheiten-
parteien entgegen, welche durch Dekret des Staatspräsidenten zudem aufgelöst werden konnten. Ähnlich ist der Fall der Türkei gelagert, wo die Feststellung der Existenz einer Minderheit einen Straftatbestand darstellt, weshalb die Gründung einer Minderheitenpartei von vorneherein faktisch kaum möglich ist. Vgl. C. Pan / B.S. Pfeil, Minderheitenrechte in Europa, Handbuch der europäischen Volksgruppen, Wien, 2006, S. $47 \mathrm{ff}$. In Griechenland wird das Vereinigungsrecht von Minderheiten 


\section{europa ethnica}

In jenen Rechtsordnungen hingegen, in welchen ethnische Parteien (oftmals sogenannte Sammelparteien $\left.{ }^{23}\right)$ ) existieren ${ }^{24}$ ), stellen diese die politische und gesellschaftliche Grundvoraussetzung dar für die Wahrnehmung der spezifischen politischen Interessen direkt durch die Minderheitenvertreter selbst und für die Erlangung einer möglichen eigenen politischen Vertretung im Parlament ${ }^{25}$.

In zahlreichen Minderheitenschutzgesetzen jüngeren Datums wird die Versammlungs- und Vereinigungsfreiheit der nationalen Minderheiten daher explizit gewährleistet und in besonderer Weise gefördert ${ }^{26}$ ).

\subsection{Minderheitenfreundliche Wahlsysteme und Wahlrechtstechniken}

Die politische Vertretung von Minderheiten hat nicht nur eine sehr starke grundrechtsrelevante Dimension (insbesondere im Hinblick auf die politischen Staatsbürgerrechte), sondern ist auch eng mit der konkreten Ausgestaltung des jeweilig anwendbaren Wahlsystems verbunden. Die Entscheidung für ein bestimmtes Wahlsystem ist eine verfassungspolitische Schlüsselfrage für jede Demokratie und hat unterschiedliche Auswirkungen auf die Effektivität der Vertretung der politischen Gruppierungen.

So ist die Entscheidung zwischen einem Verhältniswahlverfahren und einem Mehrheitswahlverfahren von grundlegender Bedeutung auch für die nationalen Minderheiten, da ein bestimmtes Wahlsystem für die Wahl von Kandidaten, die zahlenmäßig kleinere Gruppierungen repräsentieren, hinderlich, aber auch förderlich sein kann.

Die Mehrheitswahl zeichnet sich bekanntlich dadurch aus, dass die für die unterlegenen Kandidaten abgegebenen Stimmen keinerlei Einfluss auf die politischen Entscheidungen nehmen, da sie sich nicht auf die Zusammensetzung des Parlaments auswirken. Derjenigen Partei, die in einem Wahlkreis die Mehrheit der abgegebenen Stimmen auf sich vereinigen kann, fallen alle Mandate für diesen Wahlkreis zu. Die für Minderheiten abgegebenen Stimmen schlagen sich in Mandaten nicht nieder. Bedingung für die Gleichheit der Wahl ist bei der reinen Mehrheitswahl der gleiche Zählwert, nicht aber der vollständig gleiche Erfolgswert jeder einzelnen Stimme ${ }^{27}$ ). Die unterlegenen Kandidaten bleiben - anders als bei der Verhältniswahl - gänzlich von der parlamentarischen Arbeit ausgeschlossen. Damit ist das reine Mehrheitswahlrecht für kleinere politische Gruppierungen das denkbar ungünstigste Wahlsystem und somit extrem minderheitenfeindlich ${ }^{28}$ ).

Demgegenüber wird überwiegend die Auffassung vertreten, dass die Verhältniswahl ein gerechteres und „demokratischeres" Wahlsystem sei, da es allen - auch noch so kleinen - Fraktionen der Wählerschaft eine Chance auf eine - ihrer zahlenmäßigen Bedeutung entsprechende - Vertretung im Parlament ermöglicht ${ }^{29}$ ). Der Vorzug der Verhältniswahl wird gerade darin gesehen, dass die Verteilung der Parlamentssitze in möglichst genauer Übereinstimmung mit dem Stimmenanteil der verschiedenen politischen Richtungen, und somit auch der zahlenmäßig kleineren politischen Parteien wie jener der nationalen und ethnischen Minderheiten, erfolgt $\left.{ }^{30}\right)$. Das Verhältniswahlrecht begünstigt in der Regel auch stimmenschwächere Parteien, die in einer Mehrheitswahl kaum Aussicht auf Erfolg haben würden. Dies gilt allerdings nur, wenn es kein Quorum gibt, das die Zuteilung von Parlamentsmandaten von einem bestimmten Mindestprozentsatz an Wählerstimmen abhängig macht. Völlig ohne Repräsentation bleiben kleinere Gruppierungen dann nur, wenn weniger Wählerstimmen auf ihre Parteien entfallen, als zur Erringung eines einzigen Mandats erforderlich sind ${ }^{31}$ ).

dadurch eingeschränkt, dass - ausgehend von einer vollkommenen Homogenität der Bevölkerung - dies eine Gefährdung der öffentlichen Ordnung darstellen würde.

Interessant ist der Fall Spaniens, wo die ley orgánica 6/2002 de partidos políticos radikale ethnische und terroristische Aktivitäten unterbinden soll. Vgl. J. Tajadura Tejada / E. Vírgala Foruria, España, in J. Corcuera Atienza et al. (Hg.), La ilegalización de partidos políticos en las democracias occidentales, Madrid, 2008, S. 52ff. In Portugal hingegen steht der Gründung von Minderheitenparteien ganz allgemein das verfassungsrechtliche Verbot der Gründung von regionalen Parteien entgegen.

23) Dies ist etwa der Fall der SVP in Südtirol, welche mehrere ideologische Richtungen unter dem „Deckmantel“ der deutschen Minderheit miteinander verbindet.

24) Zur Notwendigkeit einer politischen Organisation von Minderheiten siehe C. Pan, Die politische Organisation nationaler Minderheiten als Voraussetzung für demokratische Mitbestimmung, in: D. Blumenwitz - G.H. Gornig - D. Murswiek, Minderheitenschutz und Demokratie, - G.H. Gornig

25) Sehr oft wird in der Literatur darauf hingewiesen, dass die Wahrnehmung eines Mitsprache- und Mitbestimmungsrechtes eine politische Vertretung der Minderheit erfordert, die wiederum nur dann möglich ist, wenn die Minderheit über eine eigene politische Organisation verfügt Die ist nicht immer der Fall und ist im europäischen Vergleich meist nur für jene Minderheiten gegeben, die über einen Schutzmachtstaat verfügen. Klassische Beispiele für Minderheiten mit einer eigenen politischen Organisation sind die Südtiroler in Italien, die Dänen in politischen Organisation sind die Südtiroler in Italien, die Dänen in
Nordschleswig, die Schweden in Finnland sowie die Deutschen in Belgien und Dänemark, welche alle in politischen Parteien organisiert sind. Dazu kommen nunmehr auch die Katalanen, Galicier und Basken in Spanien. Viele andere ethnische Gruppierungen beschränken ihre Tätigkeiten zumeist auf Vereinstätigkeiten zu kulturellen Zwecken, re ansprechp gieren, freilich ohne hierfür demokratisch legitimiert zu sein. Vgl. C. Pan, Die politische Organisation nationaler Minderheiten als Voraussetzung für demokratische Mitbestimmung, in: D. Blumenwitz - G.H. Gornig - D. Murswiek, Minderheitenschutz und Demokratie, Berlin, 2004, S.106ff. Ein Beispiel für eine politische Tätigkeit durch spezielle Kulturvereine bildet etwa die sorbische Minderheit in der Lausitz.

26) Bestimmungen finden sich zum Beispiel Art. 20, 2. Abs. Verfassung Albaniens, Art 5 Minderheitenschutzoesetz Lettlands: Art 6, Abs. 1 Minderheitenschutzgesetz in der Ukraine, Minderheitenschutzgesetz Minderheitenschutzgesetz in der Ukraine, Minderheitenschutzgesetz
in Ungarn, Polnisches Vereinigungsgesetz vom 7. April 1989. C. Pan / B.S. Pfeil, Minderheitenrechte in Europa, Handbuch der europäischen Volksgruppen, Wien, 2006.

27) In der Rechtsprechung des österreichischen Verfassungsgerichtshofs wird allerdings darauf hingewiesen, dass es sich hierbei aber um einen „potentiellen“ gleichen Erfolgswert handelt.

28) Vgl. M. Krugmann, Das Recht der Minderheiten, Legitimation und Grenzen des Minderheitenschutzes, Berlin, 2004, S. 265.

29) Vgl. F. Lanchester, Sistemi elettorali e forma di governo, Bologna, 1981, S. 40.

30) Vgl. Furlani, S. 19. Dies wurde auch vom italienischen Verfassungsgericht so dargelegt. Vgl. insbesondere die Entscheidung n. 356/1998.

31) Vgl. D. Murswiek, Wahlrecht von Minderheiten, i.Dr., S. 2. 
Diese Überlegung schließt jedoch nicht schon a priori die Möglichkeit aus, dass unter bestimmten Umständen ein Mehrheitswahlsystem für die Minderheitenvertretung förderlicher ist ${ }^{32}$ ). Dies ist vor allem dann der Fall, wenn die Minderheitengruppe in einem örtlich geschlossenen Siedlungsgebiet beheimatet ist und in einzelnen Wahlkreisen die lokale politische Mehrheit darstellt ${ }^{33}$ ). Eine Möglichkeit besteht darin, Parlamentsabgeordnete und andere Vertreter in Vertretungskörperschaften nicht oder nicht nur über Listen von politischen Parteien zu wählen, sondern in Wahlkreisen. Sind die Wahlkreise so zugeschnitten, dass Minderheiten gemäß ihrem traditionellen Siedlungsgebiet die Mehrheit der Wahlberechtigten darin bilden, haben sie die Chance, einen oder mehrere Parlamentssitze zu erringen ${ }^{34}$ ). In einigen europäischen Wahlgesetzgebungen ist daher vorgesehen, dass die Präsenz von Minderheiten bei der Ausgestaltung der Wahlkreise in Betracht zu ziehen ist, um eine eigene gewählte Vertretung dieser Gruppierungen zu begünstigen ${ }^{35}$ ).

Solcherart gestaltete Wahlrechtsgesetzgebungen sind mit dem Demokratieprinzip in vollem Umfang vereinbar Das für die Gesamtheit der Wahlberechtigten geltende Wahlrecht gilt auch für Minderheiten. Sie werden nicht bevorzugt und nicht benachteiligt. Sie haben die forma gleiche Chance auf politische Teilhabe wie alle anderen Angehörigen des Staatsvolkes.

Trotz der großen Bedeutung der Wahlsysteme für die politische Repräsentation von nationalen Minderheiten finden sich nur wenige Beispiele in den europäischen Verfassungsordnungen, in welchen ein bestimmtes die Minderheiten favorisierendes Wahlgesetz gesetzlich oder gar verfassungsrechtlich vorgesehen wird. Ein Beispiel hierfür ist etwa die Wahlordnung für den Landtag in Trentino-Südtirol, wo das Spezialstatut (ein Verfassungsgesetz) ausdrücklich ein Verhältniswahlrecht vorsieht (Art. 47, 3. Abs.). Eine ähnliche Bestimmung findet sich in der belgischen Verfassung hinsichtlich der Wahl des Senates (Art. 68, 1. Abs.).

\subsection{Die Minderheitenprivilegierung im Wahlrecht}

Eine weitere Schutzebene besteht in der Vorsehung von punktuellen Ausnahmen aus den allgemeinen Wahlregeln.

Einen klassischen Anwendungsfall findet man im Hinblick auf Verhältniswahlsysteme; diese werden ganz allgemein als minderheitenfreundlich qualifiziert, können aber auch mehrheitsfördernde Kriterien, wie z.B. das Erfordernis eines „Grundmandates“ oder eine Mindestprozentklausel (Sperrklauseln), aufweisen. Insbesondere der Mechanismus der Sperrklausel verfolgt bekanntlich den Zweck, einer allzu großen Zersplitterung der Parteienlandschaft entgegenzuwirken, um dadurch die Funktionsfähigkeit der zu wählenden Volksvertretung zu gewährleisten ${ }^{36}$ ). Dies bedeutet gleichzeitig aber auch eine Benachteiligung kleinerer Parteien ${ }^{37}$ ). Bei der Verteilung der Parlamentssitze werden nur jene Listen berücksichtigt, die eine Mindestprozentzahl der abge- gebenen gültigen Stimmen auf sich vereinigen konnten, wodurch eine Vertretung von zahlenmäßig kleineren, aber dennoch bedeutenden Teilen der Bevölkerung (sei dies eine nationale Minderheit oder eine sonstige politische Minderheit) unterbunden wird $^{38}$ ). Minderheiten haben dann oft von vornherein keine Chance, Parlamentsmandate zu erringen, weil sie weniger Wahlberechtigte haben als die Anzahl der Wählerstimmen, die zur Erreichung des Quorums erforderlich sind ${ }^{39}$ ).

32) Vgl. C. Casonato, Pluralismo etnico e rappresentanza politica: spunt per un' analisi comparata, in: Diritto pubblico comparato ed europeo, n. 2/1999.

33) Dies ist etwa der Fall der deutschsprachigen Minderheit in der Provinz von Bozen, für welche ein besonderes Mehrheitswahlsystem unter Ausnahme aus dem sonst geltenden Verhältniswahlrecht für die Wahl zum Senat beibehalten wurde. Vgl. O. Peterlini, Südtirols Vertretung am Faden Roms. Die Auswirkungen von Wahlsystemen auf ethnische Minderheiten am Beispiel Südtirols in Rom von 1921-2013, in P. Hilpold (Hg.), Minderheitenschutz in Italien, Wien, 2009., S. $38 \mathrm{f}$

34) Vgl. D. Murswiek, Wahlrecht von Minderheiten, i.Dr., S. 2.

35) So sieht etwa in Finnland das Wahlgesetz vor, dass die Provinz Åland einen eigenen Wahlkreis für die Wahl eines schwedischen Abgeordneten im nationalen Parlament bildet. Vgl. R. Hofmann, Die rechtliche Stellung der Minderheiten in Finnland, in: Frowein, J - Hofmann, R. - Oeter, der Minderheiten in Finnland, in: Frowein, J - Hofmann, R. - Oeter,
S. (Hg.), Das Minderheitenrecht europäischer Staaten, Berlin, 1993, S. $108 \mathrm{ff}$. Das ungarische Wahlgesetz bestimmt, dass der ethnische Charakter der Bevölkerung bei der Wahlkreiseinteilung Beachtung zu finden hat. Auch in der Schweiz stellen die einzelnen Kantone die Wahlkreise für die Wahl der Kammern der Bundesversammlung dar. Eine Verbindung zie Wahl der Kammern der Bundesversammlung dar. Eine Verbindung zwischen Minderheitenschutz und Wahlkreiseinteilung findet sich auch mungen über die Wahl des Senats der Republik Nr. 276/1993 sieh vor, dass in den Gebieten, in denen anerkannte Sprachminderheiten leben, das Ausmaß und die Abgrenzung der Wahlkreise „deren Zugang zur Vertretung zu begünstigen haben, und zwar auch in Abweichung von den unter den anderen Buchstaben dieses Absatzes angegebenen von den unter den anderen Buchstaben dieses Absatzes angegebenen Minderheiten in die niedrigste Anzahl von Wahlkreisen einzubeziehen."

36) Die Grenzziehung durch Sperrklauseln und die damit verbundene minderheitenfeindliche unterschiedliche Gewichtung des Erfolgswertes werfen die problematische Frage auf, wie die Belange der Funktionsfähigkeit des Parlaments mit den Geboten der Wahlrechtsgleichheit und der Chancengleichheit der politischen Parteien zum Ausgleich zu bringen ist. Nach der gefestigten und weitaus verbreiteten Ansicht in der Rechtsprechung ist eine Mindestprozenthürde trotz Verstoßes gegen Rechtsprechung ist eine Mindestprozenthürde trotz Verstoßes gegen Benachteiligung der politischen Minderheit als gerechtfertigt anzusehen. In der Lehre wird allerdings oftmals darauf hingewiesen, dass die Behauptung einer Gefahr der Parteienzersplitterung und der damit verbundenen Arbeitsunfähigkeit des Parlamentes einen hypothetischen Begründungsansatz darstellt und es demnach zu überprüfen sei, ob diese Gefahr nach Jahrzehnte währender Erfahrung tatsächlich noch bestehe. Vgl. etwa E. Becht, Die 5\% Klausel im Wahlrecht, Stuttgart, München, Hannover, 1990, S. $75 \mathrm{ff}$ und $91 \mathrm{ff}$.

37) Vgl. Krugmann, Das Recht der Minderheiten, Legitimation und Grenzen des Minderheitenschutzes, Berlin, 2004, S. 267.

38) Mindestprozentklauseln sind in fast allen Ländern vorgesehen und belaufen sich im europäischen Durchschnitt auf $4-5 \%$ der gültig abgegebenen Stimmen.

39) Die spezifische Problematik der nationalen und ethnischen Minderheiten in demokratischen Mehrheitssystemen wurde bereits von Georg Jellinek 1898 diskutiert, welcher in seinem Vortrag „Das Recht der Minoritäten " auf die Problematik der Ethnizität im Demokratisierungsprozess hingewiesen hat. Insbesondere die Mehrheitsregel ist im Hinblick auf nationale Minderheiten in ihrer Anwendung außer Kraft gesetzt und nationale Minderheiten in ihrer Anwendung außer Kraft gesetzt und
damit die ihr innewohnende Dynamik zwischen Mehrheit und Minderheit, da nationale Minderheiten niemals eine potenzielle Möglichkeit haben, bei Wahlen die Mehrheit zu bilden. Von diesen generellen Überlegungen nicht betroffen sind natürlich die Autonomiesysteme, welche in der Rege die Bevölkerungsdichte und ausbreitung der Minderheiten in Betracht ziehen und oft so ziehen und oft so ausgestaltet sind, dass die Angehörigen der Minderheit dort die Mehrheit darstellen. 


\section{europa ethnica}

Um die damit verbundenen Gefahren für den Minderheitenschutz zu vermeiden, wurde in einigen Rechtsordnungen eine ausdrückliche Ausnahme von der Rege der Sperrklausel zugunsten von Parteien nationaler Minderheiten vorgesehen. Das klassische Beispiel für diesen Ausnahmemechanismus ist $\S 6$ Abs. 3 Satz 2 des deutschen Bundeswahlgesetzes, welches vorsieht, dass die Regelungen zur Mindestprozentklausel „auf die von nationalen Minderheiten eingereichten Listen keine Anwendung “ findet. Ziel einer solchen Freistellung aus den allgemeinen wahlrechtlichen Regeln ist die Herstellung einer effektiven Chancengleichheit im politischen Wettbewerb und die Begünstigung einer verhältnismäßigen Vertretung im Parlament der zahlenmäßig unterlegenen Minderheitengruppe.

Die Rechtmäßigkeit der Privilegierung nationaler Minderheiten war stets umstritten ${ }^{40}$ ) und die verfassungsrechtliche Frage, ob das Wahlrecht Minderheiten privilegieren soll und darf, stellte im Laufe der Geschichte der BRD immer wieder Gegenstand höchstgerichtlicher Auslegung dar ${ }^{41}$ ). Das Bundesverfassungsgericht hat schließlich die Vorsehung einer Privilegierung der Gestaltungsfreiheit des Gesetzgebers überlassen. Bei den Parteien nationaler Minderheiten lägen besondere Verhältnisse vor, die mit der Situation anderer kleinerer Parteien nicht zu vergleichen seien. Die Merkmale der großen Stimmenzahl oder der Direktmandate erlange eine Partei erst im und durch den Wahlvorgang, während das Merkmal, das die Parteien nationaler Minderheiten von allen anderen Parteien unterscheide, außerhalb des Wahlvorgangs liege ${ }^{42}$ ).

Dieser Unterscheidung ist grundsätzlich zuzustimmen, da Parteien nationaler Minderheiten - unter der Voraussetzung, dass sie sich ausschließlich oder überwiegend als spezifische Interessenvertreter inrer Minderheit verstehen und dementsprechend auftreten - keine realistische Chance haben, überproportional viele Stimmen auf sich zu vereinigen.

Ausnahmen aus den Sperrklauseln zugunsten von Minderheitenparteien finden sich zudem auch im polnischen Wahlrecht zum Parlament ${ }^{43}$ ).

Auf der Ebene des EU-Parlaments ist eine Wahlrechtserleichterung in Form einer Ausnahme zugunsten nationaler Minderheiten in der Europawahlordnung Italiens vorgesehen ${ }^{44}$.

Weitere Derogationen aus den allgemeinen wahlrechtlichen Regelungen zur Begünstigung einer parlamentarischen Minderheitenvertretung betreffen die Voraussetzungen zur Einreichung von Kandidaturen und Wahllis$\operatorname{ten}^{45}$ ) sowie die Finanzierung von politischen Parteien ${ }^{46}$ ). Durch die Ausnahmen aus den allgemeinen Wahlregeln wird eine eigene Minderheitenvertretung begünstigt. In diesem Zusammenhang wird der formale Gleichheitssatz sohin interpretiert, dass eine effektive (substantielle) Gleichheit bzw. Chancengleichheit hergestellt wird. Die Vertretung wird daher begünstigt, rechtlich allerdings nicht garantiert und hängt von den Fähigkeiten der Minderheitenpartei ab, sich im politischen Wettbewerb im Verhältnis zur Größe der Minderheit zu bewähren.

\subsection{Positive Actions: Wahlrechtsgarantien als oberste Schutzebene}

Eine noch intensivere - und somit dritte - Stufe des Minderheitenschutzes durch eine politische Vertretung besteht darin, dass die Vertretung von Minderheitenparteien nicht nur begünstigt, sondern rechtlich zugesichert wird.

Dazu zählen garantierte Parlamentssitze, die exklusiv den Vertretern der Minderheiten zugewiesen werden, auch unabhängig von den tatsächlich erzielten Wahlergebnissen.

Die Vorsehung von garantierten Abgeordnetenmandaten für nationale Minderheiten hat weite Verbreitung in vielen Verfassungen der südosteuropäischen Staaten gefunden ${ }^{47}$ ).

40) Vgl. A. Kühn, Privilegierung nationaler Minderheiten im Wahlrecht der Bundesrepublik und Schleswig-Holsteins, Frankfurt, 1991, S. 301ff. In der deutschen staatsrechtlichen Literatur wurden Wahlrechtsprivilegien überwiegend als verfassungswidrig betrachtet, vgl. etwa B. Schöbener, Die wahlrechliche Privilegieung von Minderheiten - väkerrechtiche Die wahlrechtliche Privileglerung von Vorgaben und innerstaatliche Ausgestaltung in der Bundesrepublik Deutschland, in: Gilbert H., Gornig u.a. (Hg.), Justitia et Pax. Gedächtnisschrift für Dieter Blumenwitz, 2008, S. 455.

41) Vgl. BVerfGE 1, 208 (240).

42) Vgl. BVerfGE 6, 84 (S. 96 f.). Die Ausführungen des Bundesverfassungsgerichtes stellen immer wieder klar, dass eine Minderheitenpartei Ausdruck eines bestimmten Landesteils ist, "der geschichtlich ein besonderes Schicksal gehabt hat, der geographisch klar abgegrenzt ist und dessen kulturelles Gesicht durch eine nationale Minderheit mitgeprägt wird“. Wegen dieser besonderen Charakteristik hat das deutsche Bundesverfassungsgericht Parteien von nationalen Minderheiten immer von den zahlenmäßig ebenfalls kleinen „Splitterparteien“ abgegrenzt. Die Bedeutsamkeit für das Staatsleben der Minderheitenparteien wird daher nicht durch die numerische Stärke der Partei bestimmt, sondern durch die Vorsehung des Wahlgesetzgebers von Ausnahmebestimmungen zu den sonst anwendbaren Sperrklauseln. Vgl. BvG vom 5.4.52, S. 257. Weitere Sonderregelungen, die Ausdruck der Bedeutsamkeit de Minderheitenpartei für das Staatsleben sind, sind etwa die Regelungen für eine herabgesetzte Zahl von Abgeordneten, um Fraktionsstärke zu haben, oder Regelungen, die eine Mitarbeit in den Ausschüssen unabhängig von den Mehrheitsverhältnissen garantieren.

43) Cfr. C. Pan, Die Minderheitenrechte in Polen, in: C. Pan/B.S. Pfeil, Minderheitenrechte in Europa, Handbuch der europäischen Volksgruppen, Wien, 2006, S. 380.

44) Vgl. U. Haider-Quercia, La rappresentanza elettorale delle minoranze nazionali in Europa, Padova, 2013, S. 243 ff.

45) Ein Beispiel hierfür findet sich im italienischen Wahlgesetz für die Abgeordnetenkammer (Gesetz n. 361/1957). Art. 18-bis, 2. Abs. sieht mit dem Ziel, zu verhindern, dass das Quorum der für die Kandidatu notwendigen Unterschriften ein unüberwindliches Hindernis für die in dass jene Minderheitenparteien von der Pflicht zur Einbringung von Unterstützungsunterschriften befreit sind, wenn sie bei der letzten Wahl zumindest einen Sitz erlangt haben. Ein weiteres Instrument zur Erleichterung der Minderheitenrepräsentation ist die Zulässigkeit von Listenverbindungen, auch zwischen Listen, die nicht der gleichen Parte angehören. Dies ermöglicht es den Minderheitenparteien, in Verbindung mit größeren Parteien gewählt zu werden. Eine Bestimmung dieser mit größeren Parteien gewählt zu werden. Eine Bestimmung dieser
Art findet sich beispielsweise im italienischen Europawahlgesetz (Gesetz vom 24. Jänner 1979, Nr. 18), gemäß welcher bei der Mandatsverteilung Listenverbindungen der Kandidaten der deutschsprachigen, französischen und slowenischen Minderheiten mit einer anderen Partei, die in allen Wahlsprengeln angetreten ist, zulässig ist.

46) Spezielle Bestimmungen für die Finanzierung von Minderheitenparteien findet man zum Beispiel im deutschen Parteiengesetz, welches in Art. 18, Abs. 4 Parteien nationaler Minderheiten von der Erreichung einer bestimmten Mindeststimmenanzahl ausnimmt, um Recht auf Ersatz der Wahlkampfkosten zu beantragen.

47) Vgl. Palermo / Woelk, Diritto costituzionale comparato dei gruppi e delle minoranze, 2011, p. 124. 
So sieht etwa die Verfassung Sloweniens (Art. 64, 3 und 4 Absatz) vor, dass die italienische und die ungarische Minderheit jeweils über einen Vertreter im nationalen Parlament verfügen, welcher über eine zweite Stimme zusätzlich zur Stimme für das allgemeine Parlament gewählt wird ${ }^{48}$ ).

Die verfassungsrechtliche Problematik des Zweistimmenwahlrechts ist in besonderem Maße in Kroatien zutage getreten ${ }^{49}$ ), wo das derzeitige Minderheitengesetz vorsieht, dass die Angehörigen aller Minderheiten über eine zweite Stimme insgesamt acht Minderheitenabgeordnete im Parlament wählen können.

Noch umfassender garantiert die rumänische Verfassung (Art. 62, 2. Abs.) allen Organisationen nationaler Minderheiten einen Sitz im Parlament auch in Ermangelung der Mindestanzahl der für einen Sitz notwendigen Stimmen. In Dänemark wurde auf der Grundlage der territorialen Bindung der Minderheit eine Quote von zwei Sitzen für die Bewohner der Faröer Inseln und Grönlands eingerichtet (Art. 20 dänische Verfassung); eine ähnliche Vorschrift ist in der Verfassung Finnlands vorgesehen, welche in Art. 25 ein Mandat im Parlament in Helsink einem Vertreter der Åland-Inseln vorbehält. In Italien findet man den Mechanismus eines garantierten Sitzes im Statut von Trentino-Südtirol, wo festgelegt ist, dass die ladinische Minderheit auch unter Ausnahme des Verhältnismäßigkeitsprinzips im Landtag vertreten sein muss ${ }^{50}$ ).

Ein komplexes System, um die Vertretung aller Sprachgruppen im Parlament zu garantieren, auch unter Ausnahme des Verhältnismäßigkeitsprinzips, ist im belgischen Wahlrecht vorgesehen. Die belgische Verfassung legt die Anzahl der von jeder Sprachgruppe zu wählenden Senatoren fest (art. 67). Von dieser Garantiebestimmung profitiert insbesondere die deutsche Sprachgruppe, welcher die - verfassungsrechtlich gesicherte - Wahl eines Senators zusteht; auf diese Weise wird der deutschen Sprachgruppe eine leicht überverhältnismäßige politische Vertretung zugesichert ${ }^{51}$ ).

\section{Die rechtstheoretischen Spannungspunkte}

Aus dem allgemeinen Gleichheitssatz, wie er den meisten europäischen Verfassungen zugrunde liegt, folgt ebenso wenig eine unmittelbare staatliche Pflicht zur Förderung der politischen Repräsentation von Minderheiten wie aus den internationalen Gleichbehandlungsgeboten. Die Zuerkennung von Wahlrechtsbegünstigungen wird daher vor allem dem Ermessen der Mehrheitsgemeinschaft und des nationalen Gesetzgebers überlassen. Hier wie dort beinhaltet die Förderung der politischen Partizipation von Minderheitengruppen regelmäßig eine Privilegierung zum Nachteil der Mehrheit, die zwar nicht generell unzulässig ist, aber dennoch vor dem Gleichheitssatz Bestand haben muss.

In der Rechtsprechung der Gerichtshöfe der europäischen Länder wird regelmäßig auf das Rechtfertigungsgebot hingewiesen und darauf, dass, mag auch die Förderung von Minderheiten gesellschaftspolitisch wünschenswert sein, diese dennoch stets einer darüber hinausgehenden Rechtfertigung bedarf. Eine Ausnahme aus den allgemeinen Wahlregeln ist daher nur bei Vorlage eines zwingenden Grundes zulässig52). Eine Bevorzugung kann durchaus auch erfolgen, um tatsächlich bestehende Nachteile zu kompensieren, wie etwa die ungerechtfertigte Benachteiligung jener Parteien, die strukturell bedingt nie in die realistische Lage kommen können, eine politische Mehrheit zu bilden oder unter gleichen Voraussetzungen wie die Parteien der Mehrheitsbevölkerung an den Wahlen teilzunehmen.

Der Grad der zulässigen Differenzierungen zwischen Minderheiten und Mehrheitsbevölkerung richtet sich dabei vor allem nach den Wertungen, die im Rechtsbewusstsein der jeweiligen Rechtsgemeinschaft verhaftet sind. Zudem sind Vertretungsgarantien und Wahlrechtsprivilegierungen sehr oft das Ergebnis bestimmter historischer Entwicklungen und zwischenstaatlicher Beziehungen.

Im europäischen Spektrum kann man daher beobachten, dass besondere Wahlrechtsgarantien in erster Linie jenen Minderheiten zuerkannt werden, die über einen starken Schutzmacht-Staat verfügen. Demgegenüber genießen kleinere oder international weniger stark geschützte ethnische Minderheiten in den meisten Fällen kaum eigene Fördermechanismen, um in den gewählten Vertretungskörpern ihre spezifischen Interessen einbringen zu können. Im Bezug auf die Gleichheit des Wahlrechts für Minderheiten geht es daher nicht nur um die Rechtfertigung der minderheitenfreundlichen Wahlgesetzgebung gegenüber der Mehrheit, sondern auch um die unregelmäßige Anwendung der Schutzmechanismen und -praktiken aus der Perspektive der verschiedenen Minderheiten ${ }^{53}$ ).

Neben dieser Problematik der ungleichen Bedingungen der verschiedenen nationalen und ethnischen Min-

48) Vgl. C. Casonato, La rappresentanza politica della comunità italiana in Slovenia e in Croazia, p. $329 \mathrm{ff}$

49) Die vorangegangene Version des kroatischen Minderheitenschutzgesetzes hatte vorgesehen, dass nur kleine Minderheiten mit einem Anteil an der Gesamtbevölkerung von weniger als 1,5\% einen Anspruch auf einen Vertreter im Sabor haben. Die serbische Minderheit, die über eine höhere Anzahl an Angehörigen verfügt, fiel somit nicht in den Anwendungsbereich des Zweitstimmenwahlrechts und hat die Frage vor den kroatischen Verfassungsgerichtshof gebracht. Die Auslegung vor den kroatischen Verfassungsgerichtshof gebracht. Die Auslegung des kroatischen Verfassungsgerichtshofs ist interessant, da sie sich
für die Erklärung der Verfassungswidrigkeit des 2010 eingeführten Mechanismus auf die Prinzipien der Kommission von Venedig (Report on dual voting) über dieses Institut bezogen hat. Sie hat insbesondere die Bedeutung des Prinzips der verhältnismäßigen Vertretung sowie eine ungerechtfertigte Ausnahme aus dem Prinzip der Wahlrechtsgleichheit them . richts Nr. U-I3597/2010 und Nr. U-I-120/2011 vom 29. Juli 2010. Ein Kommentar dieser Entscheidungen von M. Dicosola findet sich unter www.diritticomparati.it.

50) Art. 48, 2. Abs und art. 36, 4. Abs. Vgl. T.E. Frosini, Forme di governo e partecipazione popolare, Torino, 2006, S. $196 \mathrm{ff}$.

51) Vgl. C. Pan/B.S. Pfeil, Minderheitenrechte in Europa, Handbuch der europäischen Volksgruppen, Wien, 2006, S. $50 \mathrm{ff}$.

52) Vgl. z.B. Urteil des deutschen Bundesverfassungsgerichts vom 5. April 1952 - 2 BvH 1/52.

53) Vgl. M. Krugmann, Das Recht der Minderheiten, Legitimation und Grenzen des Minderheitenschutzes, Berlin, 2004, S. 236. 


\section{europa ethnica}

derheiten im Wahlrecht ist zudem auch auf die Unterscheidung der jeweils angewandten wahlrechtlichen Förderinstrumente Bedacht zu nehmen. Aus der oben ausgeführten Unterteilung der Minderheitenschutzmechanismen im Wahlrecht geht hervor, dass die minderheitenrelevanten Mechanismen in zwei Gruppen unterteilt werden können: a) fördernde Mechanismen, die durch eine Ausnahme aus den allgemeinen Regeln eine wahlrechtliche Erleichterung für die Minderheitenpartei darstellen. Dies ist insbesondere der Fall der Freistellung von den Sperrklauseln, deren Ziel nicht die Vorwegnahme eines bestimmten Wahlergebnisses ist, sondern die Herstellung von gleichwertigen Bedingungen für den politischen Wettkampf unter Beachtung des Prinzips der verhältnismäßigen Vertretung.

Die zweite Kategorie betrifft b) Garantiemechanismen, wie garantierte Sitze im Parlament zugunsten von Minderheiten, welche über die Verwirklichung einer reinen politischen Chancengleichheit hinausgehen. Garantiemechanismen beziehen sich auf die Zusammensetzung der Wahlkörper und sehen eine strukturelle und institutionalisierte Präsenz von Minderheiten in den gewählten Vertretungskörpern vor. Es handelt sich daher in den meisten Fällen um eine überproportionale Vertretung der Minderheiten im gewählten Vertretungskörper, da Gruppierungen zum Nachteil der Mehrheit begünstigt werden, welche möglicherweise in den demokratischen Dynamiken von der Vertretung ausgeschlossen worden wären.

Die Kategorie der Garantiemechanismen ist daher einerseits für die Teilhabe der Minderheiten in den politischen Vertretungskörpern sehr effizient, verwirklicht aber eine spezifische parlamentarische Vertretung, welche in eigenen Verfahren erfolgt, die aus dem allgemeinen politischen Wettbewerb ausgenommen sind. Die Minderheitenfrage wird dadurch in gewissem Maße entpolitisiert und rechtlich garantiert und verwirklicht eine überproportionale politische Vertretung, welche über den zahlenmäßigen Anteil der Minderheit in der Bevölkerung hinausgeht.

Verfassungsrechtlich unproblematisch sind auch wahlrechtliche Privilegierungen mit nur förderndem Charakter nicht; dennoch findet darin ein gewisser Ausgleich statt zwischen dem Demokratieprinzip, welches eine formale Gleichheit aller Wahlstimmen postuliert, und dem Prinzip des Minderheitenschutzes, welches eine Differenzierung aufgrund sprachlicher und kultureller Eigenschaften der Gruppe notwendig macht.

Im Konkreten handelt es sich daher um die schwierige theoretische Vereinbarkeit des differenzierenden Minderheitenschutz mit dem demokratischen Prinzip, das sich auf die Mehrheitsregel und den formalen Gleichheitssatz stützt. Wenngleich einerseits Ziel der besonderen Vertretungsregeln für Minderheiten die Verwirklichung einer effektiven Gleichheit zwischen Angehörigen der Minderheit und der Mehrheit auch im politischen Wettbewerb ist, so ist es ebenso das Gleichheitsprinzip, das in besonderer Weise herausgefordert wird, wenn Wahlverfahren besondere Regeln für Minder- heitenparteien unter Ausnahme aus den allgemeinen Wahlrechtsregeln vorsehen ${ }^{54}$ ).

Das korrekte Funktionieren der Mehrheitsregel setzt die Gleichheit der Stimmen voraus sowie eine relative innere Einheitlichkeit des Volkes und damit die demokratische Idee der grundsätzlichen Gleichheit aller Individuen, die das Staatsvolk bilden.

Voraussetzung des Mehrheitsprinzips ist demnach der formale Gleichheitssatz, aus dem abgeleitet wird, dass alle politischen Parteien gleich zu behandeln sind und dass keine Partei einen besonderen Rechtsstatus beanspruchen kann nur aus dem Umstand heraus, dass sie eine bestimmte Gruppe der Wählerschaft oder eine nationale Minderheit darstellt.

Voraussetzung des Prinzips des Minderheitenschutzes hingegen ist die Differenzierung, d.h. eine gerechtfertigte Ausnahme aus den allgemeinen Regeln zur Förderung einer bestimmten Gruppe und zum Ausgleich effektiver Benachteiligungen ${ }^{55}$ ). Demzufolge bilden die Rechtsinstrumente, die eine besondere Vertretung von Minderheiten verwirklichen und die sich nicht allein auf die zahlenmäßigen Elemente stützen, sondern auch sprachlich-kulturelle Elemente in Betracht ziehen, eine Ausnahme aus dem - zumindest formell verstandenen - Gleichheitsprinzip.

In der europäischen Rechtstradition kann die Betrachtung der spezifischen Belange von Minderheiten durch den Gleichheitssatz in seiner materiellen Ausformung gerechtfertigt werden, es besteht aber dennoch keine rechtliche Pflicht in diesem Sinne. Der Gleichheitssatz wird nämlich nicht schon dann verletzt, wenn der Gesetzgeber Differenzierungen, die er vornehmen darf, nicht vornimmt. Die Entscheidung über die Ausgestaltung des Minderheitenschutzes ist politischer Natur, da die besonderen Eigenschaften einer nationalen Minderheit ein Element für eine Differenzierung im Wahlrecht darstellen, welches vom Gesetzgeber in Betracht gezogen werden kann, aber nicht in Betracht gezogen werden muss $^{56}$ ).

Die Lösung der grundlegenden verfassungsrechtlichen Problematiken, die mit dem Recht der Minderheiten auf eine politische Vertretung in gleichwertigen Bedingungen aufgeworfen werden, hängt daher in besonderem Maße von der Definition der verfassungsrechtlichen Prinzipen "Gleichheit" und "Demokratie“ ab. Wenn der Gleichheitssatz in einem engen Sinn ausgelegt wird, d.h. als Negation aller Unterschiede, so kann das demokratische Prinzip nur durch quantitative Elemente bestimmt werden (im Sinne eines reinen Mehrheitsprinzips). Wenn hingegen das Mehrheitsprinzip die Verschiedenheit der sprachlich-kulturellen Gruppen, die das Staatsvolk bilden, in Betracht zieht, so kann das Mehrheitsprinzip

54) Vgl. A. Pizzorusso, Minoranze e maggioranze, Torino, 1993, S. $45 \mathrm{ff}$. 55) Vgl. E. Palici di Suni Prat, Intorno alle minoranze, 2001, S. 14ff.

56) In sehr anschaulicher Weise wurde dieser Ansatz vom deutschen Bundesverfassungsgericht vertreten. Vgl. z.B. die Entscheidung vom 11 August 1954 hinsichtlich der Wahlrechtsposition des Südschleswigschen Wählerverbandes der dänischen Minderheit in Schleswig-Holstein. 
durch quantitative Elemente angereichert werden, um dadurch auch ethnische, sprachliche und religiöse Faktoren mit zu umfassen.

\section{Schlussbemerkung}

Gegenwärtig gibt es keinen gemeineuropäischen Ansatzpunkt, wonach eine Privilegierung von Minderheitenparteien im Wahlrecht verbindlich vorgesehen wird. Kaum findet sich im Völker- oder Staatsrecht ein Ansatzpunkt für eine öffentlich-rechtliche Sonderstellung der Minderheit des Inhaltes, dass inr eine privilegierte Stellung im Wahlverfahren eingeräumt werden muss, um inr unter allen Umständen eine Vertretung im Parlament zu sichern.

Dennoch lassen die meisten europäischen Verfassungsordnungen unter Anwendung des materiellen Gleichheitssatzes eine Wahlrechtsprivilegierung in dem Ausmaß zu, als dadurch eine effektive Chancengleichheit der Minderheiten auf eine verhältnismäßige Vertretung im politischen Wettbewerb verwirklicht wird. Sonderregelungen, die über das zulässige Maß der Abwandlung der Gleichheit hinausgehen, insbesondere jene, die eine überproportionale Vertretung verwirklichen, werfen hingegen schwierigere verfassungsrechtliche Vereinbarkeitsprobleme auf.

Die fördernde Wahlrechtsprivilegierung in Form von Ausnahmen aus minderheitenbenachteiligenden wahlrechtlichen Regeln nimmt unter den Vertretungs- und Partizipationsmodellen für Minderheiten in gewissem Maße eine Mittelstellung ein: Es hat eine die Minderheiten fördernde Wirkung, ohne dabei die Minderheitenvertretung durch Garantiebestimmungen aus den Dynamiken des politischen Wettbewerbs auszunehmen. Vielmehr soll eine effektive Chancengleichheit im Wettbewerb um politische Vertretung verwirklicht werden; auch wird eine politische Organisation der Minderheit vorausgesetzt, da diese nötig ist, um die strukturelle Minderheitenposition zu überwinden.

Unter dem Gesichtspunkt der freien Wettbewerbschancen der politischen Parteien als Grundlage der demokratischen Ordnung kann die Befreiung von der Sperrklausel damit gerechtfertigt werden, dass eine ethnische Minderheit die Möglichkeit erhalten soll, ihre Besonderheit, die sich aus ihrer sprachlichen und kulturellen Identität ergibt, im Parlament zur Geltung zu bringen, auch wenn die Gruppe kleiner ist als der Prozentsatz der Wähler, deren Stimmen zur Überwindung der Sperrklause erforderlich wären. Der Ausgleich dieses Nachteils besteht darin, vorgegebene faktische Ungleichheiten rechtlich zu verarbeiten und dadurch gleiche Chancen zu schaffen. Dadurch soll das strukturelle Teilhabedefizit überwunden werden, welches ein Defizit darstellt, das sich gerade aus dem Zusammenhang von Nationalstaat und Demokratie einerseits und der besonderen Stellung nationaler und ethnischer Minderheiten im Nationalstaat andererseits ergibt. Die Wahlrechtsprivilegierung der Minderheitenparteien dient somit der Verwirklichung der Demokratie und der gleichen politischen Wett- bewerbschancen und kompensiert ein im sprachlich und kulturell homogen konzipierten Nationalstaat unvermeidliches strukturelles Repräsentationsdefizit.

Im Einzelfall ist anzumerken, dass die Vorsehung von Wahlerleichterungen auf bestimmte Minderheitensituationen bezogen ist und daher in besonderer Weise situationsgebunden ist. Diese Art von Regelungen hat inren Ursprung insbesondere in den historischen und diplomatischen Gegebenheiten, die zur Bildung von Minderheitensituationen geführt haben, und ist besonders geprägt von der Beziehung der Minderheit zum Angehörigenstaat sowie zum sogenannten $\mathrm{Kin}^{-S t a t e}{ }^{57}$ ). Es geht hier daher nicht um eine abstrakte allgemein gültige favorisierende Wahlregel, sondern um die Lösung einer konkreten Minderheitensituation in einem bestimmten Staat und zu einem bestimmten Zeitpunkt ${ }^{58}$ ).

Wenn man diesen Rechtfertigungsansatz auf eine verallgemeinerungsfähige Ebene bringen möchte, kommt man freilich nicht darum herum, auch die klassischen Repräsentationskonzeptionen neu auszulegen. Um die demokratisch-parlamentarische Repräsentation auch gegenüber sprachlich-kulturellen Verschiedenheiten zu öffnen, darf die Repräsentation nicht nur auf einem formal als Einheit verstandenen Volk von gleichen Staatsbürgern basieren, sondern auch die materiellen Gleichheitsvoraussetzungen sind in die Repräsentationskonzeption einzubeziehen: Die materielle (inhaltliche) Basis des demokratischen Subjekts, der Nation, sind die allen gemeinsamen sprachlich-kulturellen Vorgegebenheiten. Haben nicht alle Staatsangehörigen an diesen Vorgegebenheiten teil, wie dies bei autochthonen nationalen oder ethnischen Minderheiten der Fall ist, besteht für sie ein eigenständiger Repräsentationsbedarf - ein Bedarf, nicht lediglich als Teil des Staatsvolkes, der sie auch sind, sondern gerade in ihrer Besonderheit repräsentiert zu werden. Die Bedeutung des allgemeinen Vertretungskörpers geht demnach dahin, dass nicht nur die Interessen bestimmter, gleichartiger Personen vertreten werden, sondern die Interessen aller innerhalb eines bestimmten Gebietes lebenden Personen.

Diese Überlegung eröffnet das rechtstheoretische Potenzial, das im Thema der Minderheitenvertretung liegt und welches Gelegenheit für eine Überdenkung der überkommenen Kategorien der liberal-demokratischen Repräsentationskonzeptionen bietet, insbesondere dahingehend, dass Elemente des gesellschaftlichen Pluralismus unter bestimmten Umständen Beachtung finden und somit positiv zur Weiterentwicklung einer

57) Vgl. U. Haider-Quercia, La rappresentanza elettorale delle minoranze nazionali in Europa, Padova, 2013, S. 251.

58) Die Wahlrechtsgleichheit muss im Rahmen des jeweiligen Staatsganzen beurteilt werden, und die Zulässigkeit von Wahlrechtsprivilegierungen muss daher auch den politischen Raum, in dem diese wirken, in Betracht ziehen. So hatte bereits Heller zumal festgestellt, dass eine Wahlrechtsbestimmung in einem Staat zu einem bestimmten Zeitpunkt gerechtfertigt sein kann und in einem anderen Staat oder zu gerech fertigt sein kann und in einem anderen Staat oder zu einem anderen Zeitpunkt nicht. Vgl. H. Heller, Gesammelte Schriften, Tübingen, 1971, Bd. 1, S. 24 


\section{europa ethnica}

zeitgemäßen Vertretung der Gesamtbevölkerung zugeführt werden können ${ }^{59}$ ).

Es bleibt angesichts der aufgezeigten Problematik schließlich der Appell an die gesetzgebende Mehrheit, im Hinblick auf die Interessen der kleinen, nicht privi- legierten und damit benachteiligten Minderheiten eine Revision des Wahlrechts in Angriff zu nehmen.

59) Vgl. C. Casonato, Pluralismo etnico e rappresentanza politica: spunti per un'analisi comparata, in: Diritto pubblico comparato ed europeo, n. $2 / 1999$, S. $625 \mathrm{ff}$

\section{Voraussichtlicher Platz für Werbung $153 \times 207,5 \mathrm{~mm}$}




\title{
Zwischen Anlehnung an Russland und Eigenständigkeit: Zur Sprachpolitik in Belarus'
}

\author{
Mark Brüggemann
}

\section{Einführung}

Im Gegensatz zum Englischen, in dem der übergreifende Begriff language policy verwendet wird, wird im Deutschen mitunter zwischen Sprachenpolitik und Sprachpolitik unterschieden. So versteht Haarmann unter Sprachenpolitik „,politische Gegebenheiten [...], die Sprachen im Hinblick auf deren Status sowie deren gesellschaftliche Funktionen einschließen“, unter Sprachpolitik „den Sachverhalt einer politisch reglementierten Sprachverwendung “. ${ }^{1}$ ) Marti dagegen verwendet den Begriff Sprachenpolitik für die „bewußte Einflußnahme auf das Verhältnis zwischen Sprachen“, während er Sprachpolitik als die bewusste Einflussnahme auf eine einzige Sprache definiert. ${ }^{2}$ ) Spolsky wiederum unterteilt Sprachpolitik in drei Gegenstandsbereiche: erstens die tatsächlichen sprachlichen Praktiken der Mitglieder einer Sprechergemeinschaft, zweitens die Werte, welche die Mitglieder der jeweiligen Sprechergemeinschaft den verwendeten sprachlichen Varietäten zuschreiben, drittens das Sprachmanagement, d.h. die Anstrengungen, die ein Teil der Mitglieder der Sprechergemeinschaft unternimmt, um die sprachlichen Praktiken anderer Sprecher zu beeinflussen. ${ }^{3}$ ) In den folgenden Betrachtungen steht der dritte Aspekt im Mittelpunkt.

Charakteristisch für die gegenwärtige weißrussische Gesellschaft ist eine Mehrsprachigkeit, die neben den beiden Staatssprachen Weißrussisch und Russisch auch die Sprachen nationaler Minderheiten wie Polnisch, Ukrainisch und Litauisch umfasst. Die Sprachpolitik gegenüber diesen Minderheitensprachen ist nicht Gegenstand des folgenden Beitrags; stattdessen soll das Verhältnis von Weißrussisch und Russisch beleuchtet werden. Um die Sprachpolitik seit der Unabhängigkeit der Republik Belarus‘ im Jahr 1991 angemessen einschätzen zu können, ist ein historischer Abriss erforderlich, der neben der Sprachgeschichte auch Aspekte der allgemeinen Geschichte auf dem heutigen weißrussischen Staatsgebiet umfasst.

\section{Geschichtlicher Überblick}

Nach den frühesten Erwähnungen in Chroniken wurde das heutige Weißrussland im 9. und 10. Jahrhundert von den Stammesgemeinschaften der Kryvičen, Dryhavičen und Radzimičen besiedelt; wichtige Siedlungszentren waren die Städte Polack und Turaŭ. ${ }^{4}$ ) Von den damals entstandenen Fürstentümern spielte lediglich Polack bis ins 13. Jahrhundert eine weitgehend selbständige politische Rolle und war maßgeblich an militärischen Auseinandersetzungen der Herrscherdynastien in der östlichen Slavia beteiligt. ${ }^{5}$ )

Ab der Mitte des 13. Jahrhunderts wurden die heutigen weißrussischen Gebiete Teil des „Großfürstentums Litauen, der Rus', Schemaitens und anderer Gebiete“, kurz meist als Großfürstentum Litauen bezeichnet. Der Staat erreichte im 15. Jahrhundert seine größte Ausdehnung von der Ostsee bis nahezu an das Schwarze Meer, die Bevölkerungsmehrheit machten Ostslaven orthodoxen Glaubens aus. Einschneidende politische Ereignisse waren die Union von Krèva (1385), die den litauischen Großfürsten Jogaila in Personalunion zum König von Polen machte, Polen und Litauen aber als selbständige Staatsgebilde beließ, und die Union von Lublin (1569), welche die Personal-in eine Realunion umwandelte und damit Polen und Litauen zur Rzeczpospolita vereinte. Als Folge der sogenannten „Polnischen Teilungen“ (1772, $1793,1795)$ gelangten die heutigen weißrussischen Gebiete vollständig unter die Herrschaft des Russischen Reichs. Unter der recht liberalen Bildungs- und Kulturpolitik von Zar Alexander I. (Herrschaft von 1801-1825) blieb die Schicht der weißrussischstämmigen Gebildeten zunächst unter dem Einfluss der dominanten polnischen Kultur und der Ansicht polnischer Gelehrter, dass die Weißrussen ethnisch-national den Polen zuzurechnen seien. ${ }^{6}$ ) Zwei Aufstände gegen die russische Herrschaft in den ehemals polnisch-litauischen Gebieten (1830/31 und 1863) führten jeweils zu einer Verschärfung der Nationalitätenpolitik. So verbot Zar Nikolaus I. 1840 für offizielle Dokumente die Bezeichnung "Weißrussland“ (Belorussija) und schrieb die Verwendung des Begriffs "Nordwestliches Gebiet Russlands“ (Severno-zapadnyj kraj Rossii) vor. ${ }^{7}$ ) Die zugleich offiziell propagierte Ideologie des "Westrussismus“ (Zapadnorussizm) betrachtete

\footnotetext{
1) Haarmann 1988, 1661.

2) Marti 1996, 274-275.

3) Spolsky 2012, 5.

4) Lojka 2001, 69.

5) Lojka 2001, 70-75.

6) Zeraschkowitsch 2001, 359.

7) Tereškovič 2004, 77.
} 


\section{europa ethnica}

die Weißrussen als Teil des russischen Volkes, der von den übrigen Russen durch die Expansion Polens und des Katholizismus entfremdet worden sei. ${ }^{8}$ )

Jedoch konnte auch ein 1867 erlassenes Verbot für den Druck im weißrussischen Idiom nicht verhindern, dass in der zweiten Hälfte des 19. Jahrhunderts eine weißrussische Nationalliteratur entstand, die auf den lokalen Dialekten basierte. ${ }^{9}$ ) Nach der Aufhebung des Druckverbots infolge der Revolution von 1905/1906 wurden weißrussische Verlage in Wilna und St. Petersburg gegründet. Mit der weißrussischsprachigen Wochenzeitung Naša Niva erschien von 1906 bis 1915 das wichtigste Periodikum der nationalen Intelligenz, zunächst noch parallel im lateinischen und kyrillischen, dann nur noch im kyrillischen Schriftsystem. ${ }^{10}$ )

Unter deutscher Besatzung Weißrusslands im Ersten Weltkrieg wurde das Weißrussische erstmals Sprache des Schulunterrichts, erste Grammatiken der weißrussischen Sprache erschienen. ${ }^{11}$ ) Infolge des Ersten Weltkriegs und des polnisch-sowjetischen Friedensvertrags von Riga (1921) wurde das heutige weißrussische Gebiet zwischen dem wieder entstandenen Polen und der Sowjetunion aufgeteilt. In der weißrussischen Sowjetrepublik (BSSR) wurde anfangs die relativ liberale Nationalitätenpolitik der Indigenisierung (karanizacyja) betrieben, deren Ziel wie in anderen Sowjetrepubliken die "Mobilisierung und Sowjetisierung der nichtrussischen Bevölkerungsmehrheiten durch Einbeziehung kulturell-nationaler Eigentümlichkeiten und Traditionen“12) war. Damit einher ging die Weißrussifizierung (belarusizacyja), die Entwicklung der weißrussischen Kultur und Sprache, und zwar u.a. die Erarbeitung einer weißrussischsprachigen Terminologie für die Wirtschaft sowie die Geistes- und Naturwissenschaften. ${ }^{13}$ ) Am Wendepunkt zu den 1930er-Jahren wurde die Politik der Indigenisierung und Weißrussifizierung aufgegeben. Mit der Losung des Kampfes gegen „nationales Abweichlertum" begann - ähnlich wie in anderen Sowjetrepubliken - die Verfolgung der nationalen Intelligenz. Nachdem auch die bisherige weißrussische Sprachwissenschaft zerschlagen worden war, wurde 1933 eine Reform des Weißrussischen beschlossen, die dieses in Orthographie, Morphologie und Wortbildung dem Russischen annäherte. ${ }^{14}$ ) Außerdem stärkte die Moskauer Führung den Status der russischen Sprache, indem Russisch 1938 als Pflichtfach in den Schulen eingeführt wurde. ${ }^{15}$ ) Der polnische Staat der Zwischenkriegszeit dagegen betrieb im heutigen Westweißrussland eine Nationalitätenpolitik, die auf eine langfristige Assimilation der weißrussischen Minderheit durch das Schulwesen und den Katholizismus abzielte. ${ }^{16}$ )

Im Zuge des Hitler-Stalin-Pakts besetzten sowjetische Truppen im September 1939 die zuvor zum polnischen Staat gehörenden Westgebiete der heutigen Staaten Weißrussland und Ukraine. Die Okkupation, die propagandistisch als "Wiedervereinigung Weißrusslands“ dargestellt wurde, brachte der BSSR einen Flächenzuwachs um 45 Prozent und einen Bevölkerungszuwachs um 46 Prozent. ${ }^{17}$ )
Das nationalsozialistische Deutschland wiederum schuf nach dem Angriff auf die Sowjetunion aus den zentralen Gebieten des heutigen Weißrussland das Generalkommissariat Weißruthenien. Trotz der Rassenideologie gestatteten die Okkupationsbehörden aus taktischen Gründen den Gebrauch des Weißrussischen in den offiziell zugelassenen Zeitungen und teilweise im Schulwesen. ${ }^{18}$ ) Gleichzeitig töteten die Deutschen Timothy Snyder zufolge von ursprünglich rund neun Millionen Bewohnern der weißrussischen Gebiete „rund 1,6 Millionen bei Aktionen hinter der Front, darunter etwa 700.000 Kriegsgefangene, 500.000 Juden und 320.000 angebliche Partisanen (in ihrer überwiegenden Mehrheit unbewaffnete Zivilisten)“. ${ }^{19}$ )

Als Nachkriegsgrenze zwischen der Sowjetunion und Polen legten die Alliierten die sogenannte Curzon-Linie fest. Die Volksrepublik Polen erhielt dadurch 17 Bezirke um Białystok und drei Bezirke um Brest. ${ }^{20}$ )

\section{Sprachpolitik in der Nachkriegs-BSSR bis zur Perestrojka}

Ein entscheidender Faktor für die sprachliche Entwicklung in den Nachkriegsjahrzehnten war die Urbanisierung der bis dahin ländlich geprägten BSSR. Marples zufolge betrug 1959 der Anteil der Stadtbewohner an der Gesamtbevölkerung 31 Prozent, 1990 dagegen mit 66 Prozent mehr als das Doppelte. ${ }^{21}$ ) Nach den Kriegsereignissen und Umsiedlungen der Nachkriegszeit wurden die Weißrussen in den zuvor polnisch, jüdisch und russisch geprägten Städten erstmals zur zahlenmäßig dominierenden Nationalität. Gleichzeitig war die BSSR in den Nachkriegsjahrzehnten die Sowjetrepublik mit dem höchsten Anteil zugezogener russischer Bevölkerung. ${ }^{22}$ ) Deren Vertreter nahmen oft berufliche Führungspositionen ein, was den Status des Russischen als Sprache des sozialen Aufstiegs verfestigte. Deshalb waren die Weißrussen, die vom Land in die Städte zogen, gezwungen, sich das Russische aktiv anzueignen, wenn sie eine Karriere im Partei- und Staatsapparat oder in der staatlich kontrollierten Wirtschaft anstreb-

\footnotetext{
8) Zeraschkowitsch 2001, 360.

9) Bieder 1991, 406

10) Bieder 2001, 452.

11) Gutschmidt 2000, 71.

12) Lindner 1999, 158.

13) Gutschmidt 2000, 75

14) Bieder 2001, 460

15) Hentschel 1997, 232

16) Bieder 2000, 206

17) Marples 2001a, 148

18) Gutschmidt 2000, 72; Bieder 2001, 459.

19) Snyder 2010, 259.

20) Marples 2001b, $166 f$

21) Marples 1996, 21

22) Sahm 1994, 20
} 
ten. Ausgangspunkt war dabei in der Regel dialektales Weißrussisch, in dem die sprachliche Erstsozialisation der meisten weißrussischen Landbewohner erfolgt war und das in der städtischen Umgebung als Zeichen von Rückständigkeit gewertet wurde. Im Zuge der Anpassung an die russischsprachige Umgebung verbreitete sich zum einen die intensiv gemischte weißrussisch-russische Rede, zum anderen ein Russisch mit punktuellen weißrussischen Merkmalen. ${ }^{23}$ )

Eine formalrechtliche Regelung über die Amtssprache(n) der Sowjetunion existierte bis zu deren Zerfall nicht. ${ }^{24}$ Die Staats- und Parteiführung forderte allerdings in der Nachkriegszeit die "gegenseitige Bereicherung“ und „Verschmelzung“ der sowjetischen Kulturen und Sprachen. Sie propagierte ein Zweisprachigkeitskonzept, nach dem Russisch als „zweite Muttersprache“ der nichtrussischen Sowjetvölker bezeichnet wurde. ${ }^{25}$ ) Praktisch schlug sich diese ideologische Linie vor allem in der Sprachpolitik im Bildungswesen nieder. Ein Gesetz, das der Oberste Sowjet der BSSR 1959 verabschiedete, machte den Weißrussischunterricht in Schulen mit Russisch als Unterrichtssprache vom Willen der Eltern abhängig. Infolge dieses Gesetzes ließen sich vor allem in den 1960er- und 1970er-Jahren zahlreiche Schüler vom Unterricht in ihrer Nationalsprache befreien. 1978 beschloss der Ministerrat der Sowjetunion zudem, bereits in allen ersten Klassen der "nationalen“ Schulen, d.h. auch in den weißrussischsprachigen Schulen, Russischunterricht einzuführen. ${ }^{26}$ ) Die Zahl der Schulen mit Weißrussisch als Unterrichtssprache sank von 9.827 im Jahr 1965 auf 3.983 im Jahr 1986. ${ }^{27}$ ) Selbst in den verbliebenen Schulen war das Weißrussische mitunter nur sehr eingeschränkt Arbeitssprache. Unterrichtsmaterialien standen oft nur auf Russisch zur Verfügung, Schülern war es erlaubt, im Unterricht auf Russisch zu antworten und weißrussischsprachige Literatur in russischer Übersetzung zu lesen. ${ }^{28}$ ) An Hochschulen, technischen und berufsbildenden Schulen wurde in russischer Sprache unterrichtet; Ausnahmen waren die Unterrichtsstunden in landesbezogenen Fächern wie weißrussische Sprache und Literatur.

\section{Weißrussisch und Russisch in der späten BSSR und der Republik Belarus"}

Mit der Perestrojka unter KPdSU-Generalsekretär Michail Gorbačev entstand in der städtischen Jugend der BSSR eine Protestbewegung, die sich gegen die als antiweißrussisch empfundene Sprach- und Kulturpolitik richtete. ${ }^{29}$ ) Insbesondere die Sprachpolitik wurde zu einem zentralen Thema im Programm der Weißrussischen Volksfront (Belaruski Narodny Front, BNF), einer Vereinigung national gesinnter Intellektueller, die 1989 gegründet wurde und sich später zu einer nationalkonservativen Partei entwickelte. Außer dem BNF engagierte sich für das Weißrussische die ebenfalls 1989 gegründete Gesellschaft für die weißrussische Sprache (Tavarystva Belaruskaj Movy, TBM).

Unter dem Eindruck der nationalen Protestbewegungen, die sich außer in Belarus‘ in mehreren Sowjetrepubliken gebildet hatten, nahm der Oberste Sowjet der BSSR im Januar 1990 ein Sprachengesetz an. Das Gesetz legte das Weißrussische als einzige Staatssprache fest, das Russische dagegen als „Sprache der interethnischen Beziehungen innerhalb der Sowjetvölker“. ${ }^{30}$ ) Innerhalb einer Übergangsfrist von jeweils drei bis zehn Jahren sollten die einzelnen Bereiche der offiziellen Sprachverwendung weißrussifiziert werden. ${ }^{31}$ ) Nach der Auflösung der Sowjetunion im Dezember 1991 übernahm die nun unabhängige Republik Belarus' diese Festlegungen.

Die eingeleitete Weißrussifizierungspolitik wirkte sich vor allem im Bildungssystem aus. Weißrussischlehrer bekamen in den Schulen eine zehnprozentige Gehaltszulage, und im Schuljahr 1993/1994 besuchten bereits 76 Prozent aller Erstklässler weißrussischsprachige Klassen. ${ }^{32}$ ) Probleme bereitete jedoch der Mangel an qualifizierten weißrussischsprachigen Lehrern sowie an Lehrwerken in weißrussischer Sprache. Zu den Gründen dafür gehörten die wirtschaftlichen Schwierigkeiten des Landes sowie die nicht in allen Bereichen ausreichend entwickelte Terminologie des Weißrussischen. Zudem lehnten weite Teile der Bevölkerung die Verwendung der zuvor marginalisierten Nationalsprache im Bildungssystem und in der staatlichen Verwaltung ab.

Den verbreiteten Unmut über die sprachliche Weißrussifizierung griff Aljaksandr Lukašènka auf, als er 1994 für die Wahl des ersten weißrussischen Staatspräsidenten kandidierte. Nach seiner Wahl startete er im Februar 1995 eine Kampagne für ein Referendum, in dem unter anderem über den Status des Russischen in Belarus sowie die weißrussische Staatssymbolik abgestimmt werden sollte. Die Staatsmedien, die in Belarus' die Meinungsbildung dominierten, verschwiegen oder diffamierten Gegner von Lukašènkas Standpunkt, nach dem das Russische in Belarus' Staatssprache sein müsse. Gegen den Widerstand des Parlaments, nach verbreiteter Meinung auch gegen damals geltendes Recht, fand das Plebiszit im Mai 1995 statt. Nach offiziellen Angaben stimmten 88,3 Prozent der Teilnehmer dafür, „der russischen Sprache einen gleichen Status wie der weißrussischen Sprache zu gewähren“, wie die Formulierung lautete. ${ }^{33}$ )

23) Zur weißrussisch-russischen gemischten Rede, der sogenannten "Trasjanka“, ist an der Universität Oldenburg ein linguistisch-soziologisches Forschungsprojekt durchgeführt worden; eine Übersicht der daraus entstandenen Publikationen ist zu finden unter http://bit. ly/1pJswBh (Zugriff: 28.6.2014).

24) Bieder 1992, 146.

25) Bieder 2001, 461f

26) Zaprudski 2007, 106.

27) Kuncevič 1999, 141

28) Kuncevič 1999, $141 f$

29) Bieder 2001, 466

30) Zaprudski 2002

31) Zaprudski 2002

32) Zaprudski 2002, Lozka 2008.

33) Zaprudski 2002. 


\section{europa ethnica}

Die Sprachgesetzgebung wurde in der Folgezeit an das Votum des Referendums angepasst. Für zentrale Bereiche des öffentlichen Lebens wurde im Sprachengesetz der Gebrauch des Weißrussischen „und (oder) “ des Russischen festgelegt, was die überkommene Dominanz der russischen Sprache weiter verfestigte. ${ }^{34}$ ) Besonders betroffen war vom erneuten sprachpolitischen Kurswechsel wieder das Bildungssystem. Gemäß den neuen Richtlinien des Bildungsministeriums waren fortan vor jedem neuen Schuljahr Elternversammlungen einzuberufen, auf denen seitdem die Eltern einzuschulender Kinder die Unterrichtssprache beantragen. Ende Mai 1995 wurde zudem an allen Mittel- und Hochschulen eine Aufnahmeprüfung in russischer Sprache und Literatur verpflichtend..$^{35}$ ) Auf Weißrussisch dagegen mussten laut Verordnung des Bildungsministeriums aus dem Jahr 2003 an allen Schulen die Fächer Geschichte Weißrusslands, Geographie Weißrusslands sowie der heimatkundliche Unterricht (Maja Radzima Belarus") gegeben werden. $\left.{ }^{36}\right) 2013$ setzte das Bildungsministerium diese Verpflichtung hinsichtlich der Fächer weißrussische Geschichte und Geographie jedoch aus und gab als Grund finanzielle Schwierigkeiten an. ${ }^{37}$ ) Der Anteil von Schülern, die Schulen mit Weißrussisch als Unterrichtssprache besuchten, sank von 75 Prozent im Jahr 1994 auf unter 20 Prozent im Jahr 2012; die meisten weißrussischsprachigen Schulen sind kleine Dorfschulen, die von Schließungen bedroht sind. ${ }^{38}$ ) Nach Angaben der Gesellschaft für die weißrussische Sprache wird auch in formal weißrussischsprachigen Schulen ein Großteil der Fächer auf Russisch unterrichtet, und es fehlt vielfach an weißrussischsprachigem Lehrmaterial. ${ }^{39}$ )

Für die Hochschulen in Belarus' gilt aktuell die Regelung, dass Studienbewerber eine Zugangsprüfung in einer der beiden Staatssprachen ablegen müssen. ${ }^{40}$ ) Als Unterrichtssprache dominiert mit Ausnahme von Fächern wie Belarussistik und Geschichte klar das Russische; eine rein weißrussischsprachige Hochschule existiert nicht. ${ }^{41}$ ) Prekär ist die Lage des Weißrussischen auch im kulturellen Bereich. Das wichtigste, bereits 1924 gegründete Filmstudio Weißrusslands, Belarus'fil'm, produziert so gut wie keine komplett weißrussischsprachigen Filme. ${ }^{42}$ ) Ausländische Filme werden fast durchgehend auf Russisch synchronisiert oder untertitelt. ${ }^{43}$ ) Weißrussische Bühnenautoren schreiben ihre Stücke ebenfalls vorwiegend auf Russisch, nicht zuletzt wegen der Aufführungsmöglichkeiten an den zahlreichen russländischen Theatern. ${ }^{44}$ ) Die Publikation weißrussischsprachiger Bücher fördert der Staat zwar - wie auch schon zwischen 1991 und 1994 - zu mindestens 50 Prozent, wissenschaftliche Literatur und Kinderbücher teils sogar vollständig. Allerdings belief sich 2009 das Zahlenverhältnis weißrussischsprachiger Buchtitel zu (in Weißrussland erschienenen) russischsprachigen Titeln nach offiziellen Angaben etwa auf 1:10.45)

Nicht besser sieht es für die weißrussische Sprache in den Medien aus. Populäre Printmedien, die noch in den 1990er-Jahren durchgehend auf Weißrussisch erschienen, sind in den vergangenen Jahren zur Zwei- sprachigkeit oder Russischsprachigkeit gewechselt. Ähnlich ist das Bild bei den elektronischen Medien. Zwar schuf man Anfang der 2000er-Jahre einige russländischweißrussische Fernseh- und Radiosender, die anstelle zuvor rein russländischer Sender ausgestrahlt wurden. Aufgrund fehlender Sprachenquoten dominierte jedoch auch in den weißrussischen Sendungen klar das Russische. Auch das traditionell weißrussischsprachige erste Fernsehprogramm wurde 2003 russischsprachig. ${ }^{46}$ ) Aktuell überwiegt bei den staatlichen Sendern eine formelle Zweisprachigkeit, wobei das Weißrussische nur eine marginale Bedeutung hat, und zwar vor allem in Sendungen zu Kultur, Geschichte und Landeskunde. Durchgehend wird die weißrussische Sprache dagegen von den regierungskritischen Exilsendern TV Belsat, Eŭraradyë (beide Warschau), Radyë Racyja (Białystok) und Radyë Svaboda (Prag; weißrussischer Dienst von Radio Free Europe) verwendet.

Die prekäre Lage der weißrussischen Sprache spiegelt sich nicht zuletzt in den Ergebnissen der Volkszählungen in den Jahren 1999 und 2009. ${ }^{47}$ ) Gaben 1999 noch $85,6 \%$ der Weißrussen das Weißrussische und nur $14,3 \%$ das Russische als Muttersprache an, so nannten 2009 nur noch 60,8\% das Weißrussische und bereits $37,0 \%$ das Russische. Auf die Frage, welche Sprache sie üblicherweise zu Hause verwenden, nannten 1999 41,3\% der Weißrussen das Weißrussische und 58,6\% das Russische; 2009 waren die Anteile 26,1\% für Weißrussisch und $69,8 \%$ für Russisch. Studien, die als Antwortkategorie die weitverbreitete weißrussisch-russische gemischte Rede hinzugenommen haben, weisen noch weit niedrigere Werte für das Weißrussische aus. ${ }^{48}$ ) Eine relativ gefestigte Stellung hat das Weißrussische dagegen in der offiziellen Toponymie. ${ }^{49}$ ) 2010 trat ein Gesetz über die Namen geographischer Objekte in Kraft. Es legte fest, dass die primäre Version von Toponymen die weißrussischsprachige sei. ${ }^{50}$ ) Die offizielle russischspra-

\footnotetext{
34) Vgl. Language Policy 2012.

35) Bieder 2008, 88

36) Mečkovskaja 2013a, 35.

37) Education 2013.

38) Lashkevich 2012.

39) Abakunčyk 2011

40) Mečkovskaja 2013b, 343

41) Smok 2012.

42) Kasymava 2013.

43) Stankevich 2013

44) So die Einschätzung von Ihar Skrypka, Dramaturg am Janka-KupalaTheater in Minsk (Černjavskaja 2012).

45) Mieczkowska 2012, 139f

46) Mieczkowska 2012, 169.

47) Ergebnisse beider Volkszählungen abrufbar unter http://belstat. gov.by (Zugriff: 16.5.2014)

48) Hentschel, Kittel 2011.

49) Smok 2012

50) Zachavaem 2014.
} 
chige Fassung entsteht demnach nicht als Übersetzung, sondern als Transliteration aus dem Weißrussischen. Die Toponymie-Kommission des Ministerrats bestätigte Ende 2012, dass dem Weißrussischen als "Nationalsprache“ von Belarus“ bei der Benennung geographischer Objekte Vorrang gebühre. ${ }^{51}$ ) Auch abgesehen von der Benennung von Siedlungen, Straßen und Gewässern sind Aufschriften und Beschilderungen im öffentlichen Raum durchaus auch auf Weißrussisch anzutreffen. Mitunter kommt in jüngerer Zeit vor allem in Minsk die lateinische Transliteration des Weißrussischen (Lacinka) hinzu.

Bereits diese Tatsachen haben prorussisch-imperiale Internetressourcen wie das Portal <www.russkie.org> veranlasst, vor einer vermeintlichen Weißrussifizierung des öffentlichen Raumes zu warnen. Die Weißrussischsprachigkeit der Toponymie und eines Großteils der offiziellen Beschilderung mache das Russische zur "ausgestoßenen“ Sprache, sei ein Verstoß gegen die staatliche Zweisprachigkeit und werde der Lage Weißrusslands als Transitland zwischen der Russländischen Föderation und der Europäischen Union nicht gerecht. ${ }^{52}$ ) Publizistische Äußerungen dieser Art sowie die Aktivitäten kremlnaher Organisationen wie Russkij Mir und Rossotrudničestvo zeigen, dass neben anderen Nachfolgestaaten der Sowjetunion auch Belarus ‘ für die auswärtige Kultur- und Sprachpolitik der russländischen Regierung von besonderem Interesse ist. ${ }^{53}$ )

Ob das Lukašènka-Regime die Sprachpolitik als außenpolitisches Faustpfand gegenüber Russland benutzt, wird in Belarus' kontrovers diskutiert. ${ }^{54}$ ) Nachdem 2007 das Verhältnis zum östlichen Nachbarn wegen eines Gaspreis-Streits abgekühlt war, gab es zaghafte Anzeichen einer gewissen Aufwertung des Weißrussischen, etwa die Ernennung des Weißrussischsprachigen Pave Latuška zum Kulturminister (2009). Diesem Eindruck widersprechen jedoch immer wieder andere Schritte, etwa 2012 ein Rundbrief der Präsidentenverwaltung, der die lokalen Behörden aufforderte, „konkrete Maß nahmen zu ergreifen, um die Politik einer erzwungenen Weißrussifizierung [...] und die künstliche Begrenzung der Russisch-Verwendung [...] zu verhindern“ ${ }^{.55}$ )

Dem ganz offensichtlichen Mangel an Förderung des Weißrussischen dagegen begegnen proweißrussische Intellektuelle und Aktivisten unterschiedlich: Vertreter der älteren Generation wie der Historiker Leanid Lyč sehen die Hauptverantwortung für die Sprachpolitik beim Staat. ${ }^{56}$ ) Sie stellen in ihren Publikationen die moralische Verurteilung des Lukašènka-Regimes und der sowjetisch-russischen Sprachpolitik in den Mittelpunkt. Auf der anderen Seite versuchen Initiativen und meist jüngere Privatpersonen, die Nachteile des Weißrussischen durch Kampagnen, Wettbewerbe und Aktionen auszugleichen. Dazu gehören etwa Preise für weißrussischsprachige Musikalben und Videoclips sowie für Werbeplakate zur Popularisierung des Weißrussischen, außerdem weißrussischsprachige Märchenbücher für Tablet-Computer, kostenlose Weißrussisch-Kurse und fachbezogene Kurse auf Weißrussisch außerhalb des offiziellen Bildungssystems. ${ }^{57}$ ) Die wohl wichtigsten
Kanäle zur Bewerbung der weißrussischen Sprache sind das Internet und hier vor allem soziale Netzwerke wie Facebook und Vkontakte, in denen es zahlreiche Gruppen zur weißrussisch-nationalen Thematik gibt.

\section{Aktuelle Einschätzung und Schluss}

Die Besetzung und anschließende Annexion der Krim zum vermeintlichen Schutz der Russischsprachigen wurde auch in Belarus' aufmerksam verfolgt. Zu Wort meldete sich neben anderen der Vorsitzende des „Koordinationsrats der russländischen Landsleute in Weißrussland “58), Andrej Geraščenko. Er erklärte nicht nur seine Unterstützung für die Krim-Politik des Kreml, sondern auch seine "Sorge“ darüber, dass in Weißrussland immer mehr die polnisch-litauische historische Orientierung die Oberhand gewinne. Als Teil dessen bezeichnete er „das Verschwinden der russischen Sprache aus der Benennung von Ortschaften, Straßen und Metro-Stationen sowie die Versuche, die Lacinka einzuführen “. ${ }^{59}$ )

Auf der anderen Seite des politischen Spektrums stehen mitunter scharfe antirussische Äußerungen nationalkonservativer Politiker Weißrusslands. So äußerte bereits kurz vor dem Euromaidan Jury Belen'ki, stellvertretender Vorsitzender der „Konservativ-christlichen Partei Weißrussische Volksfront“: „Wenn du Russisch sprichst, bist du im Heer der Besatzer und schießt auf dein Volk. ${ }^{“ 60}$ ) Den nationalkonservativen Politiker und ausgebildeten Linguisten Vincuk Vjačorka wiederum veranlasste die Argumentation der russländischen Regierung, auf der Krim seien die Rechte ethnischer Russen bedroht, Parallelen zur Position Frankreichs im Algerienkrieg zu ziehen. ${ }^{61}$ ) Das Lukašènka-Regime wiederum setzt auch weiterhin keine Anreize zum aktiven Gebrauch der weißrussischen Sprache. Der regierungsnahe Diskurs propagiert eine

\footnotetext{
51) Štefanovič 2013, Situacyja 2012.

52) Štefanovič 2013.

53) Internetadressen der beiden Organisationen: http://www.russkiymir. ru und http://rs gov ru (Zugriff: 4.5.2014). Zur Gründungsgeschichte und Mission der Stiftung Russkij Mir vgl. auch Gasimov 2012.

54) Vgl. z.B. Drakachrust 2010.

55) Zit. n. Lashkevich 2012

56) Z.B. Lyč 2012.

57) Razumoǔski 2014, Cjarėnceŭ 2013, Lashkevich 2012, Kazka 2013 , Majdas 2014, Maǔčanava 2013

58) Solche Koordinationsräte der russischen Diaspora existieren in zahlreichen Ländern. Organisatorisch und finanziell sind sie eng an das russische Außenministerium angebunden. VgI. MFA 2007.

59) Karnej 2014.

60) Belen'ki 2013.

61) Rakicki 2014. Der Vergleich hebt auf die Gruppe der pieds noirs ab, (überwiegend) französischstämmige Bewohner Algeriens, die im algerischen Unabhängigkeitskrieg auf der Seite Frankreichs kämpften. Die hisrischen Unabhängigkeitskrieg auf der Seite Frankreichs kämpften. Die historischen und territorialen Gemeinsamkeiten sowie die kulturelle Nähe einer „prototypischen “ Kolonialsituation wie in Algerien problematisch. Abgesehen davon war die indigene Bevölkerung Algeriens formalrechtlich durch den Code de l'indigénat gegenüber den Französischstämmigen benachteiligt, während in der Sowjetunion ethnische Russen zwar de facto, nicht aber de iure bessergestellt waren.
} 
"demokratische Zweisprachigkeit“ und verschweigt die faktische Benachteiligung der weißrussischen Sprache. Gleichzeitig unterlässt Lukašènka aber beleidigende Äußerungen gegen die Sprecher des Weißrussischen, wie sie für die frühen Jahre seiner Amtszeit charakteristisch waren. ${ }^{62}$ ) Auch eine gewisse symbolische Aufwertung der Sprache im öffentlichen Raum ist erkennbar. Einher geht dies mit der vorsichtigen Übernahme von Elementen der weißrussisch-nationalen Gedenkkultur, ohne dass das grundsätzlich prosowjetische und prorussische Geschichtsbild dadurch negiert würde. So versucht Lukašènka einerseits, sein alterndes sowjetnostalgisches Elektorat um gemäßigte Anhänger einer proweißrussischen Orientierung zu erweitern. Andererseits hält er "großrussisch"-chauvinistische Kräfte im Land schwach, die bei einem allzu proweißrussischen Kurs die Karte sprachlicher Unterdrückung ausspielen und Russland um „Schutz“ bitten könnten.

\section{Bibliographie}

Abakunčyk, Halina (2011): „Belaruskaja mova - čužaja va ŭlasnaj chace“, http://www.svaboda.org/content/article/24340399.html (Zugriff: 27.12.2013)

Belen“ki 2013 = „Jury Belen“ki: Kali ty havoryš pa-rasejsku - ty ŭ vojsku akupantaŭ“, https://www.youtube.com/ watch?v=N8GZIZ5ygiw (Zugriff: 7.4.2014)

Bieder, Hermann (1991): „Die erste und zweite Wiedergeburt der weißrussischen Sprache und Kultur“, in: Bieber, Ursula Woldan, Alois (Hg.): Georg Mayer zum 60. Geburtstag. München: Otto Sagner, 405-451.

Bieder, Hermann (1992): „Die gegenwärtige sprach- und kulturpolitische Entwicklung in Weißrussland“, in: Die Welt der Slaven, 16, 1992, 142-168.

Bieder, Hermann (2000): „Konfession, Ethnie und Sprache in Weißrußland im 20. Jahrhundert“, in: Zeitschrift für Slawistik 45, 2000, 200-214.

Bieder, Hermann (2001): „Der Kampf um die Sprachen im 20. Jahrhundert“, in: Beyrau, Dietrich, Lindner, Rainer (Hg.): Handbuch der Geschichte Weißrußlands. Göttingen: Vandenhoeck \& Ruprecht, 451-471.

Bieder, Hermann (2008): „Die Sprachpolitik der Ukraine und Weißrusslands im Kontext internationaler Sprachplanung“, in: Braselmann, Petra, Ohnheiser, Ingeborg (Hg.): Frankreich als Vorbild? Sprachpolitik und Sprachgesetzgebung in europäischen Ländern. Innsbruck: Innsbruck University Press, 79-97.

Brüggemann, Mark (2014): Die weißrussische und die russische Sprache in ihrem Verhältnis zur weißrussischen Gesellschaft und Nation: Ideologisch-programmatische Standpunkte politischer Akteure und Intellektueller 1994-2010. Oldenburg: BIS-Verlag. (Studia Slavica Oldenburgensia 23)

Cjarènc'eŭ, Zmicer (2013): „A ty razmaŭljaeš pa-belarusku? Zrabi krok naperad!“, http://nn.by/?c=ar\&i=117672 (Zugriff: 13.2.2014)

Černjavskaja, Julija (2012): „Bez otvetov. Možno li vlijat‘ na sud'bu naroda, sidja v intellektual'nom getto?", http://news. tut.by/society/300209_print.html (Zugriff: 19.4.2014)

Drakachrust, Jury (2010): „Mova jak pole boju: 1995-2010“, http://www.svaboda.org/content/transcript/2044999.html (Zugriff: 20.2.2014)

Education $2013=$ „Education in Belarusian language severely marginalized“, http://belarusinfocus.info/p/6062 (Zugriff: 27.12.2013)
Gasimov, Zaur (2012): „Idee und Institution. Russkij mir zwischen kultureller Mission und Geopolitik“, in: Osteuropa 5, 62, 69-81.

Gutschmidt, Karl (2000): „Sprachenpolitik und sprachliche Situation in Weißrußland seit 1989“, in: Panzer, Baldur (Hg.): Die sprachliche Situation in der Slavia zehn Jahre nach der Wende. Frankfurt am Main etc.: Lang, 67-84.

Haarmann, Harald (1988): „Sprachen- und Sprachpolitik“, in: Ammon, Ulrich et al. (Hg.): Sociolinguistics. (Handbücher zur Sprach- und Kommunikationswissenschaft Band 3, Halbband 1) Berlin et al.: de Gruyter, 1660-1678.

Hentschel, Gerd (1997): „Rußland, Weißrußland, Ukraine: Sprachen und Staaten der ,slavischen Nachfolge“ von Zarenreich und Sowjetunion“, in: Hentschel, Gerd (Hg.): Über Muttersprachen und Vaterländer. Frankfurt am Main etc.: Lang, 211-240.

Hentschel, Gerd, Kittel, Bernhard (2011): „Weißrussische Dreisprachigkeit? Zur sprachlichen Situation in Weißrussland auf der Basis von Urteilen von Weißrussen über die Verbreitung „ihrer Sprachen“ im Lande“, in: Wiener Slawistischer Almanach 67, 107-135.

Karnej, Igor“ (2014): „Krymskij urok dlja Belorussii“, http:// www.svoboda.org/content/article/25292238.html (Zugriff: 14.03.2014)

Kasymava $2013=$,Marharyta Kasymava: ,Belaruskija fil‘my pavinny byc ' belaruskamoŭnymi““, http://www.svaboda. mobi/a/25208272.html (Zugriff: 16.2.2014)

Kazka 2013 = „Peršaja belaruskamoŭnaja kazka dlja ajpada“, https://www.youtube.com/watch?v=0gLvx3ppx-s (Zugriff: 27.12.2013)

Kuncevič, L. P. (1999): „Dvujazyčie v sfere narodnogo obrazovanija“, in: Bulyko, A. N., Krysin, L. P. (Hg.): Tipologija dvujazyčija i mnogojazyčija v Belarusi. Minsk: Belaruskaja navuka, 139-147.

Language Policy $2012=$ „A review of language policy in Belarus“, http://tbm-mova.by/monitoring15.html?lang=en (Zugriff: 22.6.2012)

Lashkevich, Kanstantsin (2012): „Selling Russian to the Russians“, http://belarusdigest.com/story/selling-russianrussians-8919 (Zugriff: 20.2.2014)

Lindner, Rainer (1999): Historiker und Herrschaft. Nationsbildung und Geschichtspolitik in Weißrußland im 19. und 20. Jahrhundert. München: Oldenbourg.

Lojka, Pawel (2001): „Der Zerfall der Kiewer Rus und das Fürstentum Polozk (9. bis 12. Jahrhundert)“, in: Beyrau, Dietrich, Lindner, Rainer (Hg.): Handbuch der Geschichte Weißrußlands. Göttingen: Vandenhoeck \& Ruprecht, 69-79.

Lozka, Ales“ (2008): „Stan belaruskamoŭnaha navučannja na 2008“, http://nastaunik.info/national_edu_and_upbr/3 (Zugriff: 16.6.2012)

Lyč, Leanid (2012): „Ruskaja kul'tura ŭ Belarusi: prablemy harmaničnaha suisnavannja z nacyjanal'naj“, in: Naša slova, 34-35, 22.-29.8.2012, 6-7;6.

Majdas, Nina (2014): „Ščodry večar: z anšlaham pačaŭsja novy sezon kursaŭ belaruskaj movy“, http://generation.by/ news6433.html (Zugriff: 16.2.2014)

Marples, David R. (1996): Belarus. From Soviet Rule to Nuclear Catastrophe. Basingstoke, London: Macmillan.

Marples, David R. (2001a): „Die Sozialistische Sowjetrepublik Weißrußland (1917-1945)“, in: Beyrau, Dietrich, Lindner, Rainer (Hg.): Handbuch der Geschichte Weißrußlands. Göttingen: Vandenhoeck \& Ruprecht, 135-152.

62) Ausführlich hierzu Brüggemann 2014, 109-150. 
Marples, David R. (2001b): „Die Sozialistische Sowjetrepublik Weißrußland (1945-1991)“, in: Beyrau, Dietrich, Lindner, Rainer (Hg.): Handbuch der Geschichte Weißrußlands. Göttingen: Vandenhoeck \& Ruprecht, 166-177.

Marti, Roland (1996): „Sprachenpolitik in den Grenzgebieten der Slavia“, in: Marti, Roland (Hg.): Sprachenpolitik in Grenzregionen. Saarbrücken: SDV, 273-303.

Maǔčanava, Maryna (2013): „Vyvučac‘ prahramavanne pabelarusku? Calkam mahčyma!“, http://bit.ly/1bRk4sw (Zugriff: 5.3.2014)

Mečkovskaja, Nina (2013a): „Jazykovoe zakonodatel'stvo v Belarusi i Ukraine kak dokumenty vremeni: social'nye determinanty, pravovye rešenija i lakuny, ideologičeskij kamufljaž“, in: Gladkova, Hana, Vačkova, Kina (eds.): Jazykové právo a slovanské jazyky. Praha: Filozofická fakulta Univerzity Karlovy, 31-57.

Mečkovskaja, Nina (2013b): „Belarus“,, in: Gladkova, Hana, Vačkova, Kina (eds.): Jazykové právo a slovanské jazyky. Praha: Filozofická fakulta Univerzity Karlovy, 337-354.

MFA 2007 = „Über die erste Sitzung des Koordinationsrates der russischen Landsleute“, http://bit.ly/1iKBSsW (Zugriff: 14.03.2014)

Mieczkowska, Nina (2012): „Stulecie białoruskiego odrodzenia narodowego: główne wydarzenia i trendy samoświadomości językowej i sytuacji językowej na Białorusi“, in: Radzik, Ryszard (ed.): Tożsamości zbiorowe Białorusinów. Lublin: Wydawnictwo UMCS, 105-186.

Rakicki, Vjačaslaŭ (2014): „Rasejskamoŭe - nepaz'bežny šljach da anėksii?“, http://www.svaboda.org/content/article/25302767.html (Zugriff: 30.4.2014)

Razumoŭski, Anton (2014): „Experty.by vyznačac“ lepšy belaruskamoŭny al‘bom 2013 hoda“, http://www.racyja. com/index. php? id=103\&zoom=21907\#. UvyrRUJ5Mmx (Zugriff: 13.2.2014)

Sahm, Astrid (1994): Die weißrussische Nationalbewegung nach der Katastrophe von Tschernobyl (1986-1991). Münster: Lit Verlag.
Situacyja 2012 = „Situacyja z zakonam ab heahrafičnych nazvach“, http://by-mova.livejournal.com/1041324.html (Zugriff: 29.3.2014)

Smok, Vadzim (2012): „Bilinguism in Belarus: Civil Society vs. the State“, http://belarusdigest.com/print/12543 (Zugriff: 28.12.2013)

Snyder, Timothy (2010): Bloodlands. München: C. H. Beck.

Spolsky, Bernard (2012): „What is language policy?“, in: Spolsky, Bernard (ed.): The Cambridge Handbook of Language Policy. Cambridge etc.: Cambridge University Press, 3-15.

Stankevich, George (2013): „On the Official Bilingualism in Belarus“, in: Belarusian Review, Summer 2013, 13-14.

Štefanovič, Aleksandr (2013): „Russkij jazyk stanovitsja v Belorussii izgoem?“, http://www.russkie.org/index. php?module=fullitem\&id=28255 (Zugriff: 29.3 .2014 )

Tereškovič, Pavel (2004): Ėtničeskaja istorija Belarusi XIX načala XX veka. Minsk: BGU.

Zachavaem 2014 = „Zachavaem belaruskija nazvy! (abnoŭlena)“, http://www.tbm-mova.by/news_718.html (Zugriff: 20.3.2014)

Zaprudski, Syarhey (2002): „Language policy in the Republic of Belarus in the 1990s“, http://www.belarusguide.com/ culture1/literature/Belarusian_Language_Prosecution_in_ Belarus.htm (Zugriff: 16.6.2012)

Zaprudski, Siarhiej (2007): „In the grip of replacive bilingualism: the Belarusian language in contact with Russian“, in: International Journal of the Sociology of Language, 183, 2007, 97-118.

Zeraschkowitsch, Pawel (2001): „Ethnischer Wandel und Nationalitätenpolitik in den weißrussischen Provinzen (1795-1914)“, in: Beyrau, Dietrich, Lindner, Rainer (Hg.): Handbuch der Geschichte Weißrußlands. Göttingen: Vandenhoeck \& Ruprecht, 359-376.

\section{Voraussichtlicher Platz für Werbung $153 \times 97,0 \mathrm{~mm}$}




\section{europa ethnica}

\section{Nach der Abstimmung in Schottland}

Nur vier von 32 Wahlbezirken haben für die Unabhängigkeit Schottlands gestimmt, die übrigen waren, zum Teil recht deutlich, dagegen. Die von der englischen Politik und vielen Medien angekündigte Katastrophe hat nicht stattgefunden. Folgerichtig hat der schottische Regierungschef Alex Salmond nur wenige Stunden später seinen Rücktritt bekanntgegeben.

Zwar hatte die britische Regierung die Abhaltung eines Referendums gestattet, wahrscheinlich weil sie von dessen Erfolglosigkeit überzeugt war, als jedoch kurze Zeit vor dem Abstimmungstermin einzelne Umfragen auf einen Sieg des Unabhängigkeitslagers hindeuteten, brach (nicht nur in London) Panik aus. Hastig wurden Reformvorschläge veröffentlicht, die bislang nicht einmal diskutiert werden konnten, der ehemalige Premierminister Brown wurde reaktiviert, und die Londoner Politik wies auf die vielen Unsicherheiten hin, die die Unabhängigkeit mit sich bringen würde (und von denen sie einen großen Teil selbst zu verantworten gehabt hätte). Furcht (vor Unsicherheiten) und Hoffnung (auf wirkliche Reformen) verschafften den Anhängern der staatlichen Einheit eine Mehrheit, die deutlich genug ist, um sie derzeit nicht infrage zu stellen.

Folgerichtig wollten die ersten englischen Politiker schon am Tage nach der Abstimmung zur Tagesordnung übergehen und die rasch gemachten (und wenig präzisen) Versprechungen auf Eis legen. Premierminister Cameron dürfte erfahren genug sein, um zu wissen, dass das nicht möglich sein wird. Dennoch: Die Chancen sind groß, dass die Anhänger der Unabhängigkeit von den Konzessionen nicht überzeugt werden. Sollten diese zu bescheiden ausfallen, wird das Thema Unabhängigkeit nach kurzer Zeit wieder auf die Tagesordnung kommen - immerhin haben fast $45 \%$ der Wähler sich dafür ausgesprochen, unter innen vor allem die jüngeren. Auf der anderen Seite ist heute noch nicht absehbar, wie die staatliche Neuordnung des Vereinigten Königreiches aussehen wird. Zurzeit überwiegt die Auffassung, dass es zu grundlegenden Veränderungen in seinem staatlichen Aufbau kommen muss.

Natürlich sind die Unabhängigkeitsbewegungen im übrigen Europa wenig erfreut. Sie versuchen jedoch, sich von der Entwicklung in Schottland abzukoppeln. Eines wird man allerdings festhalten müssen: Die bestehenden Staaten und die Anhänge des Status quo werden in jedem Falle mit dem Faktor der Unsicherheit argumentieren, einer Unsicherheit, die in Grenzen zu halten sie gefordert wären. Es wird jedes Mal auch - wenn nicht vor allem - um Furcht und Zuversicht gehen.

Vielleicht wäre es sinnvoll, wenn sich die Politiker die Frage stellten, wieso in den letzten beiden Jahrzehnten in verschiedenen Staaten (nicht nur) der EU autonomistische und Unabhängigkeitsbewegungen massiv erstarkt sind. Denn noch vor wenigen Dezennien schien das Thema nicht aktuell zu sein: Nur in Euskadi war die Forderung nach Unabhängigkeit von Spanien seit dem Ende der Franco-Diktatur populär. Das hing damit zusammen, dass die europäische Konstruktion noch in den Achtzigerjahren von einem stärkeren Zusammenwachsen ihrer Mitglieder und einem gleichzeitigen Bedeutungsverlust der existierenden Staaten ausging. Diese sollten nach und nach Kompetenzen nach oben, also nach Brüssel, und nach unten, also an Regionen und Kommunen, abgeben. Auf diese Weise würde, was einer einheitlichen Regelung bedürfte, für ganz Europa entschieden, ansonsten würden sich die Entscheidungsebenen den Bürgern annähern. Gleichzeitig sollte die symbolische Bedeutung der Staaten zurückgehen. Damit sollte dem staatlichen Nationalismus Einhalt geboten und die praktische Demokratie gestärkt werden. Diese Politik entsprach den
Vorstellungen der Väter der europäischen Konstruktion nach dem Zweiten Weltkrieg, denn sie wollten eine Wiederholung von kriegerischen Auseinandersetzungen zwischen den Mitgliedern unmöglich machen. Das Fernziel sollte ein Staatenbund, möglicherweise eine noch engere Konstruktion sein.

Langsam näherte sich die EU diesem Ziel an, bis 1989/90 die politische Umwälzung in Mittel- und Osteuropa die Prioritäten neu setzte. Auch nach dem Maastricht-Vertrag von 1992 wäre es wichtig gewesen, den internen Ausbau der Union voranzutreiben. Stattdessen wurde sie relativ rasch erweitert, um viele Staaten des ehemaligen sozialistischen Lagers (notdürftig) einzubinden. Anstatt zu einer Vertiefung kam es zur Verflachung, einer Erweiterung, die auch Staaten umfasste, die gerade erst ihre staatliche Souveränität (wieder) bekommen hatten, schwierige Prozesse der inneren Neuordnung durchlaufen mussten - mit einem Wort, denen an einer Abgabe von Hoheitsrechten, die sie gerade erst errungen hatten, wenig gelegen war. In etlichen der neuen Mitgliedstaaten sind die Umstellungskrisen bis heute nicht überwunden. Es kam zu einer massiven Re-Nationalisierung der Politik der Staaten, auch bei einigen westeuropäischen Mitgliedern der EU. So wollte Großbritannien sich niemals wirklich integrieren, und Spanien versuchte, vor allem seit den mittleren Neunzigerjahren, den Kompromiss der Verfassung von 1978 zurückzunehmen. Für Deutschland wurde die Integration der ehemaligen DDR zur Priorität; die europapolitische Konzeptionslosigkeit nahm unter der Kanzlerschaft Merkels noch zu (das lässt sich u.a. an ihrer wenig glücklichen Personalpolitik erkennen). Frankreich hatte der Neuverteilung der Kompetenzen immer reserviert entgegengestanden. So kommt es, spätestens seit der Jahrtausendwende, zu einer zunehmenden Re-Nationalisierung der europäischen Politik. Die konservativen Mehrheiten in Europa sorgen außerdem dafür, dass wenig inspirierte und schon gar nicht charismatische Politiker, die den nationalstaatlichen Prärogativen zustimmen (müssen?), in vorderster Linie der Europa-Politik stehen. Seit dem Ende der Periode Delors stagniert das Projekt Europa.

Die Re-Nationalisierung führt dazu, dass sich Minderheiten in den einzelnen Staaten immer weniger verstanden sehen. Sie müssen erkennen, dass ihre Hoffnungen auf die europäische Konstruktion und eine damit einhergehende neue Verteilung von Kompetenzen und größere Entscheidungsfreiheit nicht erfüllt werden. Eine technokratische und immer offener neo-kapitalistische EU vermag zwar den Krümmungsgrad von Gurken vorzuschreiben, das große Ziel einer demokratischen europäischen Union und die Berücksichtigung der Interessen der Bürger bleiben auf der Strecke. Dadurch erst gewinnen Bewegungen an Bedeutung, die feststellen, dass sie, wollen sie ihre Interessen wirksam vertreten, politisch eigenständig sein müssen. Vermutlich ist in dieser Hinsicht jetzt schon viel Porzellan zerschlagen. Erst eine Rückkehr der EU zu ihren ursprünglichen Zielen (unter Umständen unter Verzicht auf Mitglieder, die die Union nur als Finanzierungshilfe oder als Freihandelsinstrument ansehen) kann, mit großer Geduld, die Rufe in manchen Regionen nach politischer Unabhängigkeit leiser werden lassen. Auf der anderen Seite ist es wohl nicht überflüssig, in Erinnerung zu bringen, dass das Selbstbestimmungsrecht der Völker eines der - oft verletzten - Grundprinzipien des internationalen Rechts ist. Und Rechte sind nur Rechte, wenn sie auch in die Praxis umgesetzt werden können. Insofern war die Abstimmung in Schottland für ganz Europa von Bedeutung. Die nächste Entscheidung wird mit Spannung erwartet.

Georg Kremnitz 


\section{Literatur}

Nada Bodiroga-Vukobrat/Gerald G. Sander/Sanja Barić (Hg.): Unsichtbare Minderheiten. Hamburg: Verlag Dr. Kovac, 2013 , 324 S. € 89,90.

Der Titel dieses Buches muss unter Minderheitenrechtlern Aufmerksamkeit auf sich ziehen: Unsichtbare Minderheiten. Ein unüblicher Begriff, der sofort Assoziationen mit jenem der „neuen“ Minderheiten weckt. ${ }^{1}$ ) Tatsächlich beziehen sich einige der Beiträge gerade auf Gruppierungen, die gemeinhin diesen „neuen“ Minderheiten zugeordnet werden: so bspw. auf Homosexuelle, Frauen aus der Gruppe der Zuwanderer oder HIV-Kranke. Daneben finden sich aber noch zahlreiche andere Untersuchungen zu Gruppen, die bislang nicht den „neuen“ Minderheiten zugeordnet worden sind, ja ganz generell nicht mit der Minderheitenproblematik in Verbindung gebracht werden: außereheliche Verbindungen, registrierte Partnerschaften in grenzüberschreitenden Situationen, Personen, die einer Altersdiskriminierung ausgesetzt sind, und Verbraucher. Zwei Beiträge beziehen sich auf Themenstellungen, die üblicherweise im Kontext von „Sprachenrechten in der EU“ diskutiert werden: „Das Recht auf Benutzung der Muttersprache bei der Kommunikation mit EU-Organen - Sprecher kleiner Nationalsprachen als unsichtbare Minderheit in der EU?“ (Gerald G. Sander) und „Minority Languages in Official Use - the Case of Spain“ (von Vesna Crnić-Grotić). ${ }^{2}$ )

Auf der Grundlage welcher rechtsdogmatischer Überlegungen diese völlig unterschiedlichen Situationen unter einen einheitlichen Minderheitenbegriff zusammengeführt worden sind, wird allerdings nicht ersichtlich. Möglicherweise kann tatsächlich de Begriff der „unsichtbaren Minderheit“ eine Basis schaffen für die Erfassung von Diskriminierungstatbeständen, die wechselseitige Parallelen aufweisen, womit auch ein Ansatzpunkt für die Entwicklung gemeinsamer Schutzinstrumente entwickelt werden könnte. Auf diese Frage geht dieses Buch jedoch nich weiterführend ein. Einen ersten interessanten Ansatz dazu hätte der einführende Beitrag von Bernd Baron von Maydel geboten, der jedoch in den nachfolgenden Beiträgen nicht aufgegriffen bzw. vertieft wurde. So bleibt dieses Buch eine interessante Zusammenstellung von Diskriminierungssituationen, die Aufmerksamkeit verdienen, die aber in rechtlicher Hinsicht überwiegend nicht unter die Minderheitenthematik subsumiert werden können.

Peter Hilpold

Antonio Bravo Nieto/Juan Antonio Bellver Garrido/Sonia Gámez Gómez (Hg.): Chafarinas. El ayer y el presente de unas islas olvidadas, (2 Bände; Bd. 37+38, Aldaba), Melilla: UNED, 2013 262 S. + 237 S. $€ 20,-$ (Gratis-Download: http://www.uned.es/ ca-melilla/Webmel1/biblo/Aldaba.htm).

Zum ersten Mal wird hier in einer zweibändigen Publikation von drei WissenschaftlerInnen aus Melilla die Geschichte eine Inselgruppe präsentiert, die seit 1848 einen Teil Spaniens darstellt. Die Islas Chafarinas - die Isla del Congreso, die Isla de Isabel II und die Isla del Rey - sind drei kleine Inseln ca. 3 Kilometer vor der marokkanischen Küste. Die Isla de Isabe II hatte ehemals auch eine kleine Zivilbevölkerung - manche Quellen sprechen von über 1.000 Personen -, die in der Folge des Spanisch-Marokkanischen Krieges in den 20er-Jahren des 20. Jahrhunderts langsam die Inseln verlassen haben, und beherbergt heute einen Militär- und Forschungsstützpunkt.
Üblicherweise werden die Inseln - wenn überhaupt - in einem Atemzug mit anderen spanischen Territorien wie Melilla und Ceuta oder Alhucemas und Vélez de la Gomera genannt. Ihre Geschichte unterscheidet sich jedoch grundsätzlich von den anderen Gebieten, die ihrerseits viel früher von Kastilien erobert wurden: Melilla 1497, Vélez de la Gomera 1508 (und neuerlich 1564), Alhucemas 1560. Ceuta wurde bereits im Jahre 1415 von Portugal erobert und fiel an Kastilien, als es 1580 seine Unabhängigkeit verlor und Teil der kastilischen Krone wurde. Die Eroberung der Chafarinas fand Jahrhunderte später statt, als Spanien bereits fast alle Überseekolonien in Amerika verloren, und deshalb verstärkt seine Aktivitäten nach Afrika verlegt hatte.

Während der erste Band Themen wie Geologie, Natur und Meeresbiologie, Vorgeschichte und Archäologie, Kartographie und Militärarchitektur gewidmet ist, befasst sich der 2. Band mit der Sozialgeschichte seit 1848 dieser kleinen Inselgruppe. Abgesehen von steinzeitlichen Siedlungen waren die Inseln bis zu diesem Tage auch gar nicht besiedelt - fehlende Süßwasservorkommen machen dies auch unwahrscheinlich. Erst nach dem Spanisch-Marokkanischen Krieg und dem Friedensvertrag von Wad Ras aus 1860 erkennt Marokko die Zugehörigkeit der Inseln zu Spanien an.

Die ersten „Siedler“ waren Soldaten und Strafversetzte. Relativ früh kam auch Zivilbevölkerung aus Spanien hinzu. 1887 wurden 703 Einwohner gezählt. Ein regelmäßiger Postschiffverkehr wurde ab Mitte des 19. Jahrhunderts zwischen Melilla und den Chafarinas eingerichtet. Eine Volksschule wurde eröffnet. In den Jahren 1921 bis 1926 kommt es erneut zum Krieg zwischen Spanien und Marokko, in dessen Folge große Teile der Zivilbevölkerung die Inseln in Richtung Melilla verlassen. 1952 wird die Kirche restauriert, ein vergeblicher Versuch, wieder Zivilisten anzuziehen. 1978 wird die einzige Post-und Telegraphenstation geschlossen. 1986 verlassen die letzten Zivilisten die Inseln. (Bd. 2, S. 111).

Die Inseln werden heute vom Militär und von Melilla aus verwaltet. Zivilisten ist der Zutritt untersagt. Seit dem Jahr 2000 existiert das sog. Instituto de Cultura Mediterránea auf den Chafarinas, ein Forschungsinstitut, das sich hauptsächlich um Ausgrabungen einer steinzeitlichen Siedlung kümmert.

Diese Publikation präsentiert reich illustriert die Geschichte einer Inselgruppe, die kurioserweise immer noch zu Spanien gehört. Für Marokko gelten die Inseln - ebenso wie die Städte Melilla und Ceuta und die Inseln Vélez de la Gomera, Alhucemas und die Petersilinsel - als besetztes Gebiet, das dekolonisiert werden soll. Dieser Punkt wurde wahrscheinlich bewusst ausgespart.

Max Doppelbauer

Carmine Chiellino/Natalia Shchyhlevska (Hg.): Bewegte Sprache. Vom ,Gastarbeiterdeutsch“ zum interkulturellen Schreiben. Dresden: Thelem, 2014, 284 S. € 49,80.

Die Arbeitsmigration nach dem Zweiten Weltkrieg hat unter anderem einen bemerkenswerten literarischen Aspekt: In ihrer

1) Vgl. dazu P. Hilpold, Neue Minderheiten im Völkerrecht und im Europarecht, in: 42 Archiv des Völkerrechts 2004, S. 80-110.

2) Vgl. zu diesem Themenbereich auch P. Hilpold, „Die europäische Sprachenpolitik - Babel nach Maß?“, in: 45 Europarecht 5/2010, S. 695-710 sowie ders., „Die Sprachenregelung der Union zwischen Grundfreiheiten und Kulturpolitik“, in: 19 Zeitschrift für Europäisches Privatrecht 3/2011, S. 500-517. 


\section{europa ethnica}

Folge entsteht Literatur, die von Betroffenen geschrieben wird Das bedeutet, dass Angehörige sozialer Gruppen die Feder in die Hand nehmen, deren Vorläufer (Arbeitsmigration ist bekanntlich ein sehr altes Phänomen) das nicht tun konnten, gewöhnlich weil sie Analphabeten waren. Ihre Nachkommen im 20. Jahrhundert sind so weit alphabetisiert, dass einige von innen zu Autoren werden (ihren in der jeweiligen Heimat verbliebenen Zeitgenossen aus ähnlicher Gesellschaftsschich widerfährt das kaum). Diese Literatur entsteht überall dort, wo Arbeitsmigration eine bestimmte soziale Bedeutung und einen hinreichenden Umfang bekommt. Im deutschen Sprachraum dürfte Gianni Bertagnolis Arreviderci Deutschland!, Stuttgart 1964 das erste Beispiel sein, in Großbritannien beginnt woh mit Sam Selvons The Lonely Londoners, London 1956 (vgl. Sigrid Löffler, Die neue Weltliteratur und ihre großen Erzähler, München: Beck, 2014) und Frankreich mit Ousmane Sembènes Le dockeur noir, Paris 1956 die Bewegung schon über ein Jahrzehnt früher (ich spreche hier nur von der Literatur von Arbeitsmigranten, die Kolonialliteratur reicht in beiden Ländern weiter zurück).

In Deutschland setzt die wissenschaftliche Beschäftigung mit dem Phänomen der Migrationsliteratur in den späten Siebzigerjahren ein, nicht sehr lange nachdem sich zugewanderte Schriftsteller im Aufnahmeland zu Wort gemeldet haben. Sie hat sich seitdem in einer Wellenbewegung entfaltet. Der vorliegende Band möchte eine Brücke von diesen Anfängen zu einer aus differenzierteren Betrachtung in der Gegenwart schlagen. Das bringt mit sich, dass er nicht nur die Texte von eingewanderten Arbeitern betrachtet, sondern sehr unterschiedliche Kategorien von Migranten ins Auge fasst. Da stehen neben José F.A. Oliver (*1961 als Sohn andalusischer Arbeiter im Südschwarzwald) Yokô Tawada (*1960 Tokio), die als ausgebildete Intellektuelle nach Deutschland kam und blieb, oder Paul Celan (1920 Czernowitz -1970 Paris) und Herta Müller (*1953 Nitzkydorf/ Rumänien), die aus anderen Gründen in den deutschsprachigen Raum gelangten (Celan verließ inn nach kurzem Aufenthal definitiv wieder). Ich weiß nicht, ob die Aufgabe einfacher wird, wenn man Migranten mit ganz unterschiedlichem Hintergrund und Migrationsmotiven ohne weiteres nebeneinanderstellt.

Der Band umfasst neben einem präsentierenden Vorwor der Herausgeber elf Beiträge, die letztlich vor allem aus zwei Forschungszentren hervorgehen, nämlich den Universitäten Augsburg und Mainz. Den Anfang macht Dieter Lamping mit einem Text über Adelbert von Chamisso (1781-1938), „,Ein armer unbedachter Gast"“ (15-25), in dem er versucht, die Unterschiede zwischen Chamisso und seinen „Enkeln“ (so werden die heutigen Literaten aus der Migration oft genannt, allerdings verbindet sie mit Chamisso allenfalls das Schreiben in der Sprache des Landes der Zuflucht) aufzuzeigen. Chamisso, auf den Lamping nicht zum ersten Male zu sprechen kommt, war Romantiker und Kosmopolit, ein Welt-Reisender und Skeptiker, der sich nur schwer mit seinen "Nachfahren“ vergleichen lässt. Am bemerkenswertesten in diesem Aufsatz sind zweifellos die Zitate Thomas Manns aus dem Jahr 1911 aus denen hervorgeht, wie wenig dieser dem Zuwanderer die Beherrschung einer sekundär gelernten Sprache zutraute. Diese Zitate erklären hinlänglich, warum der Sprachwechse von Autoren im Gefolge des Nationalismus so unverständlich blieb (und letztlich als "Verrat“ empfunden wurde) und warum das Phänomen lange Zeit (nicht nur im deutschen Sprachraum) weitgehend tabuisiert wurde.

Carmine Chiellino stellt in seinem Beitrag die Frage .,Gastarbeiterdeutsch ' als solidarische Sprache für die Einwanderer oder für eine interkulturelle Literatur in deutscher Sprache?" (27-53). In einem breiten historischen Panorama betrachtet er verschiedene soziale Varietäten des Deutschen, muss aber schließlich zu der Erkenntnis kommen, dass das „Projekt, Gastarbeiterdeutsch als solidarische Sprache für die Einwanderer gescheitert" sei (S. 49), da zum einen die Voraussetzungen zu disparat gewesen seien, zum anderen die nachfolgenden Generationen es nicht fortführen konnten (ebda.). Aber wäre das nicht von Beginn an eine Überforderung gewesen? Diese Autoren haben Gewaltiges geleistet, indem sie sich selbst sichtbar gemacht und die deutsche Sprache durch ihre Beiträge offener und reicher gemacht haben. Wäre mehr zu erhoffen gewesen? In ihrem Text „Wie verhält sich eine interkulturelle Sprache? Eine Fallstudie am Beispiel der Werke José F. A. Olivers“ (54-87) zeigt Ana Ruiz, wie das Spanische (Kastilische) als ,latente Sprache“ (S. 61) im Werk des Autors für gedankliche Interferenzen sorgt. Oliver schreibt ihrer Meinung nach (fast nur) für einen „interkulturellen Leser“, der sich in beiden Sprachen bewegen kann (ibid.). Bisweilen stellt sich für den Leser der Textbeispiele die Frage, ob der Autor darüber hinaus nicht bewusst für eine sehr enge Leserschaft schreibt. Ob man darüber hinaus „interkulturelle Intertextualität“ als „Instrument zum bewussten Aufbau eines direkten Dialoges zwischen zwei oder mehreren Sprachen“ (S. 84) bezeichnen kann, weiß ich nicht. Ist nur die Formulierung unglücklich oder das dahinterstehende Konzept? Adrian Bieniec befasst sich in seinem Text „Vom Umgang mit der Sprache eines vermeintlichen Kulturvermittlers. Radek Knapps Erzählband Franio“ (88-104) letztlich mit einem ähnlichen Problem, wenn auch sozusagen spiegelverkehrt. Er zeigt, dass Knapp dem Leser die Rezeptionsarbeit stärker erleichtert (und damit möglicherweise eine weitere Rezeption - vor allem nicht nur durch die happy few - erreicht).

Die beiden folgenden Aufsätze befassen sich mit zwei Autoren, die sich den Konventionen der deutschen Schrift- (und Literatur-)Sprache weitgehend entziehen. Pasquale Gallo schreibt über „Feridun Zaimoglus Kanak Sprak und German Amok oder die Faszination für das ,koloniale Wort"“ (105-121) und Ulrike Reeg über „Mehrsprachigkeit, Sprachinszenierung und Rezeption. Überlegungen zu Texten von Zé do Rock“ (122-138). Gallo vermerkt, dass Zaimoglus Texten ein "herber Kolonialgeruch“ entströmt (S. 114, Hervorhebung im Original), mithin bringt er die Existenz des sogenannten Gastarbeiters in die Nähe des europäischen Kolonialismus und stützt sich dabei u.a. auf Stefan Zweigs Amokläufer. Diese Beobachtung verdient Aufmerksamkeit, denn der Autor rückt damit zwei Komponenten der europäischen Geschichte - meines Erachtens mit Recht - in einen Zusammenhang, der oft vernachlässigt wird. Zé do Rocks Texte lesen sich vor allem als sprachliche Experimente. Die Vf. fragt zu Recht, ob die betont gesellschaftskritische Haltung des Autors nicht durch dieses spielerische Vorgehen "geradezu überdeckt" (S. 131) wird.

Yokô Tawada ist im engeren Sinne keine Arbeitsmigrantin. Die Japanerin wollte als Praktikantin im deutschen Buchhandel arbeiten, entschloss sich dann „aus Neugier und Experimentierfreudigkeit" (S. 140, das Zitat ist aus Chiellinos Band Interkulturelle Literatur, Stuttgart/Weimar: Metzler, 2000, S. 272 übernommen) zu einem Germanistikstudium in Deutschland, wo sie blieb. Marion Greins Aufsatz ,Yokô Tawada [...]: die etwas andere Migrantin. Interkulturalität als literarisch-sprachliche Erfahrung“ (139-166) meint zu erkennen, dass „das Lernen von Sprache zentrales Thema Tawadas" (S. 162) sei; sie stellt aber infrage, dass die „Relation von Sprache und Wahrnehmung derart fest" (ibid.) sei wie von Tawada angenommen. Ob es für die Feststellung dieser Relation indes ein objektives Maß gibt? Natalia Shchyhlevska zeigt in ihrem ausgezeichneten Aufsatz .Intertextuelle Referenzen und literarische Mehrsprachigkeit in Zwischenstationen und Schimons Schweigen von Vladimir 
Vertlib“ (167-204), wie der Autor die Mehrsprachigkeit der dargestellten Situationen mit unterschiedlichen Mitteln darstellt, um sie dem deutschsprachigen Leser näherzubringen, wie er auch Inhalte aus der einen Gesellschaft in der anderen verständlich macht (wenn auch manche seiner Hinweise sicher nur für wenige Leser erkennbar sind: wer hat heute den aus Galizien stammenden Autor Karl Emil Franzos, 1848-1904, und sein einst berühmtes Werk Aus Halb-Asien auf Anhieb präsent?). Die Autorin weist mit Nachdruck darauf hin, dass Vertlib „mit beiden Sprachen in seinem Werk behutsam und verantwortungsvoll um[geht]“ (S. 203).

Raluca Dimian-Hergheliciu weist in ihrem Text „,Bis jetzt denke ich vieles nicht in Worten ...' Sprache und Bilder bei Herta Müller und Paul Celan“ (205-218) auf Parallelen zwischen den Sprachkonzeptionen beider Autoren hin - während der sprachliche Relativismus Müllers evident ist, lässt sich Ähnliches aufgrund seiner Bindung an die deutsche Sprache auch bei Celan vermuten, mir scheinen indes auch erhebliche Unterschiede zwischen beiden zu bestehen, die eine genauere Betrachtung wert wären. Chantal Wright zeigt in inrem Text „,L'épreuve de l'étranger“: Franco Biondi's style in english translation" (219-246) die Probleme auf, die ein in verschiedenen sprachlichen Varietäten, die dazuhin konnotiert sind, geschriebener Text bei der Übersetzung aufwirft. Welche Entsprechungen sind vom Ursprung des Textes her akzeptabe und für die zielsprachigen Leser nachvollziehbar?

Szilvia Lengl untersucht in ihrer Arbeit „Der Preis der Loyalität Beispiele des Verzichts auf das kulturelle Gedächtnis im Roman Totalschaden von Que Du Luu“ (247-280) das Schreiben der Autorin, die 1973 in Vietnam als Angehörige der dortigen chinesischen Minderheit geboren, bereits als kleines Kind mit inren Eltern geflohen ist, in Herford aufwuchs und in Bielefeld studierte. Ihr erster Roman Totalschaden (Leipzig: Reclam, 2006) schildert die Geschichte eines deutschen, in Bielefeld lebenden Studenten. Allerdings hat Que Du Luu das Deutsche zur Sprache ihres literarischen Schaffens gemacht, da sie diese als inre Muttersprache ansehe (so in ihrer Dankrede zur Verleihung des Chamisso-Förderpreises 2007, S. 248). Diese Strategie ist bei Zuwanderern aus Vietnam nicht ganz einmalig, es gab in Berlin kurze Zeit einen Vizekanzler, der sich ebenfalls damit schwertat, seine Herkunft aus Vietnam zu thematisieren. Szilvia Lengl konstatiert, dass Que Du Luus Erstlingsroman „im eindeutigen Gegensatz zu den Erstlingswerken anderer zweisprachiger Autoren ihrer Generation“ (S. 278) steht. Natürlich wird man bei der Autorin eine gewisse Entfremdung (der Begriff der sprachlichen Entfremdung wurde vor fast fünfzig Jahren von dem okzitanischen Gelehrten Robert Lafont vorgeschlagen und nicht genügend rezipiert) unterstellen dürfen. Lengl indes mach der Autorin den Vorwurf, wenn „Que Du Luu ihre Erinnerungen an [...] eine andere Sprache Patrick Müller geradezu verweigert, limitiert sie die Figur“ (S. 279). Mir scheint, dass sie damit implizit einfordert, dass Autoren mit Migrationshintergrund wie Autoren mit Migrationshintergrund schreiben müssen. Damit bewegt sie sich aber nicht mehr im Bereich der Literaturwissenschaft, sondern in dem der Therapie. Man kann den Roman ablehnen, aber das sollte dann in diesem Kontext mit literarischen, nicht mit psychologischen Argumenten geschehen.

Vielleicht suggeriert der Untertitel des Bandes eine vorgegebene Richtung der Entwicklung, die mitunter zu einem gewissen Systemzwang führt. Abgesehen davon liest er sich als Auffächerung der Möglichkeiten des Schreibens vor einem mehrsprachigen Hintergrund, wenn auch die große Ausweitung des Rahmens der als Beispiele gewählten Autoren bisweilen den Vergleich und das Erkennen von Gemeinsamkeiten erschwert. Da und dort hätte er sorgfältiger lektoriert werden sollen, so war Gabriel García
Márquez Kolumbianer und nicht Mexikaner, wenn er auch lange Zeit in Mexiko lebte und dort starb (S. 63), und der Autor der Chants de Maldoror hat sich als (fiktiver) Comte de Lautréamont in die französische Literaturgeschichte eingeschrieben, wenn er auch standesamtlich schlicht Isidore Ducasse hieß (S. 83). Trotz der erwähnten kleinen Reserven kann der Band einen guten Überblick über Aspekte des Schreibens auf Migrationshintergrund heute geben.

Georg Kremnitz

European Yearbook of Minority Issues, vol. 10. Martinus Nijhoff, 2011, 724 S. € 350,-.

A new issue of the EYMI has been published and again it constitutes a rich source of information and analysis on minorityrelated issues. Joshua Castellino and Katheleen Cavanaugh open up the Yearbook with a contribution on "The Role of Law in the Minority Discourse in the Middle East" where they examine the present upheavals in the Middle East, and in particular the Arab Spring, from a minority rights perspective. They thereby demonstrate that the history of the Middle East is rich of models that make the cohabitation of different linguistic and ethnic groups possible.

Francesco Palermo writes about "Current and Future Challenges for International Minority Protection". As an international lawyer dealing with minority rights the present reviewer takes pride on Palermo's statement that “international law has been rapidly evolving from a marginal topic into one of the most important areas of international law", although I fear that not all internationalists would subscribe to this vision (with the exception of course, of the internationalist who also have a special focus on minority rights). Palermo identifies a series of challenges for present-day minority law and among them the need to overcome the old dichotomy between "old" and "new" minorities ${ }^{1}$ ) as well as the task to find new approaches for integration to which this reviewer fully subscribes. ${ }^{2}$ )

In the next contribution, Kyriaki Topidi deals with the highly interesting question whether the Copenhagen criteria are undermined by the Lisbon Treaty. She evidences that the conditionality policy practiced by the EU with regard to candidates for EU membership had led to double standards and has in the meantime been all but abandoned. With the Lisbon Treaty some progress has been made towards the creation of a true EU minority policy applicable also internally but there is still a long way to go to meet the high expectations developed more than two decades ago.

Boshko Stankovski examines the implications of Kosovo Independence for the Doctrine of Constitutional Self-determination. In his contribution, Stankovski develops a somewhat unorthodox theory about Kosovo's purported right to self-determination. He maintains that Kosovo has been a constitutive entity of the former SFRY since the establishment of post-World War II Yugoslavia and holds the belief that the findings of the Badinter Commision of 1992 about the Yugoslav disintegration process should not be read as a barrier for claims to self-determination by Kosovo as this Commission referred to Article 5 of the Con-

1) See in this regard P. Hilpold, Das Kosovo-Problem - ein Testfall fü das Völkerrecht, in: 68 ZaöRV 2008, pp. 779-801; Secession in International Law: Does the Kosovo Opinion Require a Re-Assessment of this Concept?", in: P. Hilpold (Hrsg.), Kosovo and International Law, Martinus Nijhoff: Leiden/Boston 2012, pp. 47-78 and The ICJ's Advisory Opinion on Kosovo: Perspectives of a delicate question, in: 14 Austrian Review of International and European Law 2009 (2013), pp. 259-310.

2) See P. Hilpold/Ch. Perathoner (eds.), Die Schutzfunktion des Mutterstaates im Minderheitenrecht, NWV et al.: Vienna et al. 2006. 


\section{europa ethnica}

stitution of the SFRY and this article lists also the autonomous provinces. Stankovski ignores, however, not only that Kosovo had de facto lost the status of an autonomous province in 1989 but also that the Commission was clearly not prepared to apply the uti possidetis principle to provinces. It seems hardly possible to derive a right to self-determination from the Arbitration Commission 's Opinions on the basis of what the Badinter Commission could have said or should have said had it applied the „correct” historic perspective. ${ }^{3}$ )

Dimitry Kochenov, Vadim Poleshchuk and Aleksejs Dimitrovs deal in their contribution entitled "Do Professional Linguistic Requirements Discriminate?" with the highly problematic practice by Estonia and Latvia to impose professional linguistic requirements beyond what seems directly necessary for the efficient exercise of a specific job. They correctly point out that questions of proportionality and indirect discrimination are here at issue. A highly interesting contribution, entitled "Soft Solutions to a Hard Problem: Justiciable Minority Rights?" has been written by Geoff Gilbert. He examines the question what would be the merit in pursuing the task of adding a protocol to the European Convention for the Protection of Human Rights and Fundamental Freedoms dedicated to the protection of minority rights. While admitting that such an approach would give minorities a stronger standing within this protection system he expresses compelling doubts about the wisdom to follow a strongly judicia approach in minority protection and to duplicate the successfu activities by the Advisory Committee of the Framework Convention for the Protection of National Minorities.

A specific focus is set by the Yearbook on the situation of Roma minorities and the relevant articles offer a rich panoply of views on this specific question. This part of the Yearbook is truly interdisciplinary with contributions by Yaron Matras and Barbara Tiefenthale that adopt a prevailingly sociological perspective and articles by Kristin Henrard and Roberta Medda-Windischer (two zealous contributors to the EYMI) who undertake a legal analysis. Peter Vermeersch, Yana Kavrakova, Márton Rovid, Stephan Müller and Rumyan Russinov analyze the Roma issue under the perspective of "Political Frameworks, Institutions and Participation".

Many more contributions would deserve specific mention, in particular also those regarding the recent practice of international organizations and national institutions in the field of minority protection. On a whole it can again be stated that the EYMI is a highly valuable instrument for dealing with minority issues on the academic level.

Peter Hilpold

3) See extensively on the Kosovo question P. Hilpold, Kosovo and International Law. The ICJ Advisory Opinion of 22 July 2010" (ed.), Brill: Leiden 2012 and P. Hilpold, The ICJ Advisory Opinion on Kosovo: different perspectives of a delicate question, in: 14 Austrian Review of International and European Law 2009 (2013), pp. 259-310, also available at: http:// papers.ssrn.com/sol3/papers.cfm?abstract_id=1734443.

G.H. Gornig/H.-D. Horn/D. Murswiek (Hg.): Das Selbstbestimmungsrecht der Völker - eine Problemschau. Berlin, Ducker \& Humblot, 2013, 206 S. $€ 78,90$.

Dieser Sammelband enthält eine Reihe von Beiträgen, die das Selbstbestimmungsrecht der Völker aus unterschiedlichen Perspektiven beleuchten. So beschäftigt sich Grego Ploch mit dem Thema der Volksabstimmungen nach dem Ersten Weltkrieg, durch welche in sehr bescheidenem Rahmen das Wilsonsche Prinzip der Selbstbestimmung umgesetzt werden sollte. Besonderes Augenmerk schenkt der Autor dabei dem Referendum in Oberschlesien. Die zwei zentralen juristischen Beiträge stammen von Christian Hillgruber („Wer ist Träger des
Selbstbestimmungsrechts und wie kann man es durchsetzen? - Rechtsinhaberschaft und Rechtsdurchsetzungsmacht“) und Dietrich Murswiek („Offensives und defensives Selbstbestimmungsrecht“). Beide Autoren befürworten eine breitere Definition der Anspruchsberechtigung, wobei sie aber auch auf eine diesbezüglich sehr zurückhaltende Staatenpraxis verweisen. Christian Hillgruber betont zu Recht, dass auch der Kosovo-Fall nicht als Präzedenzfall für die Etablierung eines Selbstbestimmungsanspruchs von Völkern im ethnischen Sinne angesehen werden könne. ${ }^{1}$ ) Dietrich Murswiek führt in seinem Beitrag eine Diskussion fort, zu welcher er schon seit vielen Jahren grundlegende Beiträge leistet und in deren Rahmen er die Existenz eines Selbstbestimmungsanspruchs auch ethnischer Völker, zumindest für den Fall ihrer existenzgefährdenden Bedrohung, vertritt. Auch in der Verselbständigung des Kosovo sieht er Ansätze, die seine Position bestärken. Dabei fordert er allerdings von der Staatengemeinschaft eine Kohärenz ein, die sie in der Praxis oft nicht an den Tag zu legen bereit ist. So blendete der IGH in seinem Kosovo-Gutachten zahlreiche zentrale Fragestellungen einfach aus und deutete die vorgelegte Fragestellung in einer Form um, dass die Antwort darauf auf fachlicher Ebene banal, in politischer Hinsicht aber ungefährlich werden sollte. ${ }^{2}$ ) René Kuppe beschäftigt sich in seinem Beitrag mit dem Thema „Indigene Völker und Selbstbestimmungsrecht“. In der Deklaration der UN-Generalversammlung über die Rechte indigener Völker vom 13. September 2007 wurde den indigenen Völkern ein Selbstbestimmungsanspruch zuerkannt, der aber keinen Sezessionsanspruch beinhaltet, sondern als Anspruch auf „innere Selbstbestimmung“, als Recht auf Autonomie und Partizipation zu werten ist. Den Abschluss des Buches bilden zwei Beiträge über das Selbstbestimmungsrecht in Israel/Palästina, wobei der philosophisch gehaltene Beitrag von Godel Rosenberg einen Appell zum friedlichen Zusammenleben von Juden und Palästinensern enthält, während Abdullah Hijazi Israel eine Reihe von Rechtsverletzungen, insbesondere aber die Verweigerung des Selbstbestimmungsrechts zugunsten der Palästinenser, vorwirft. Interessant wäre hier eine Auseinandersetzung mit den Bemühungen um eine Zwei-Staaten-Lösung gewesen sowie eine Prüfung der Frage, welche Hindernisse einer solchen Lösung nun tatsächlich noch entgegenstehen. Immerhin standen die diesbezüglichen Verhandlungen in den letzten Jahren immer wieder knapp vor dem Durchbruch. Auch dem jetzigen US-Außenminister John Kerry muss ehrliches Bemühen zur Erreichung einer solchen Lösung bescheinigt werden.

Insgesamt ist dieses Buch in vielem Ausdruck einer „typisch deutschen “ Sicht ${ }^{3}$ ) des Selbstbestimmungsrechts, was sich z.T. auch in der Auswahl der zitierten Literatur niederschlägt. Dies ist keineswegs ein Kritikpunkt, hat doch die deutsche Wissenschaft ganz grundlegende Beiträge zur Fortentwicklung der Selbstbestimmungsdiskussion geleistet ${ }^{4}$ ), die aber im angloamerikanischen Bereich häufig ignoriert werden. ${ }^{5}$ )

1) Vgl. dazu ausführlich P. Hilpold, Das Kosovogutachten des IGH vom 22 Juli 2010, Brill 2012; ders., The ICJ's Advisory Opinion on Kosovo: Perspectives of a delicate question, abrufbar unter: http://papers.ssrn.com/ sol3/papers cfm?abstract id=1734443, publiziert auch in: 14 Austrian Review of International and European Law 2009 (2013), S. 14 Austria Review of International and European Law 2009 (2013), S. 259-310. 2) Ibid.

3) Zur „typisch deutschen“ Sicht auf das Völkerrecht Th. Giegerich/A. Zimmermann, "Typisch deutsch“ - Is There a German Approach to International Law? - Introduction, in: 50 GYIL 2007, S. 15-27.

4) Vgl. dazu auch L. Palleit, Völkerrecht und Selbstbestimmung - Zum Begriff des Selbstbestimmungsrechts der Völker in der duetschen und österreichischen Völkerrechtswissenschaft 1918.-1933, Nomos: Baden-Baden 2008.

5) Dies habe ich in meinem Beitrag .Von der Utopie zur Realität - das Selbstbestimmungsrecht der Völker im Europa der Gegenwart-, in: 68 Juristen-Zeitung 22/2013, S. 1061-1070 näher ausgeführt. 
Eine Übersetzung dieses Werkes ins Englische wäre damit durchwegs empfehlenswert. So sei bspw. darauf hingewiesen, dass Dietrich Murswieks Beitrag „The Issue of Right of Secession - Reconsidered“', in: Christian Tomuschat (Hg.), Modern Law of Self-Determination, 1993, S. 21-39, international großen Anklang gefunden hat. Die Verwendung der englischen Sprache hat die Brücke zur angloamerikanischen Rechtswelt geschaffen, die - und das ist ein betrübliches, aber unumstößliches Fak tum - deutschsprachige Beiträge leider weitgehend ignoriert.

Peter Hilpold

Dilek Güven: Nationalismus und Minderheiten. Die Ausschreitungen gegen die Christen und Juden der Türkei vom September 1955. Südosteuropäische Arbeiten. München, Oldenbourg, 2012, 198 S. € 29,80.

Die pogromartigen Ausschreitungen gegen die Christen und Juden der Türkei vom September 1955 stellten einen Wendepunkt in den Beziehungen der muslimischen Mehrheit mit den nichtmuslimischen Minderheiten des Landes dar. Die Ereignisse, die sich damals in Istanbul und in anderen Städten der Türke ereigneten, wurden von der Autorin Dilek Güven wissenschaftlich aufgearbeitet, da sie einen Einschnitt in die Geschichte des Landes darstellen. Güven veröffentlichte anlässlich des 50. Jahrestages der Ausschreitungen bereits 2005 ein Buch zu diesem Thema und promovierte im darauffolgenden Jahr an der Ruhr-Universität Bochum. Das vorliegende Buch basiert auf der deutschen Erstfassung von 2006. Die türkische und die griechische Fassung aus den Jahren 2005 und 2006 lösten eine überwiegend positive Reaktion in der Öffentlichkeit aus. Das öffentliche Interesse an der Monographie über die Gewalttaten vom September 1955 war enorm.

Der Forschungsgegenstand wurde von der Autorin im Übergang vom Vielvölkerstaat des Osmanischen Reiches zum türkischen Nationalstaat verortet. Es bedürfe einer grundlegenden Rekonstruktion der Ereignisse, da diese in der historischen türkischen Forschung bisher nicht existiere. Die bis zu diesem Zeitpunkt erschienenen wenigen publizistischen Darstellungen stellten keine intensive Forschung und Beschäftigung mit der Thematik dar. Diese wurde bisher lediglich im innenpolitischen Kontext de Türkei behandelt und war weder Gegenstand historischer Forschung noch in die türkische Nationalgeschichte eingebettet. Auf gearbeitet wurde dies anhand von intensiver Archivarbeit in den staatlichen Archiven der Türkei und Griechenlands und in Zusammenarbeit mit den ausländischen diplomatischen Vertretungen. Einen weiteren wichtigen Punkt zur Aufarbeitung der Geschehnisse stellte die Durchführung von Zeitzeugeninterviews dar. Die Autorin geht nach einer Erläuterung ihres methodischen Vorgehens im zweiten Kapitel ihres Buches auf die detaillierte Rekonstruktion der September-Ereignisse über, in der sie zunächst auf die Angriffsphase eingeht. In diesem Abschnitt zeig sie das Vorgehen der Beteiligten bei den Zerstörungen und de ren Unterstützung durch militärische Kräfte auf. Ausführungen zum ausbleibenden Einschreiten der Ordnungskräfte in Bezug auf die angegriffene Minderheit schließen sich im folgenden Abschnitt an. Die Reaktion der muslimischen Bevölkerung auf die Ausschreitungen war anders, als sie bisher durch den türkischen Staat dargestellt worden war, da diese sich teilweise für die Christen und Juden einsetzte und Angriffe auf deren Geschäfte und Häuser verhinderte. Neben den Ausschreitungen in Istanbul kam es auch in Izmir, Ankara und andernorts zu Übergriffen auf die christliche und jüdische Bevölkerung des Landes. Während es in Izmir zu Übergriffen auf Konsulate und einen griechischen Messestand kam, beschränkten sich die Ereignisse in der Hauptstadt auf Protestkundgebungen. Es kam nicht zu Gewalttätigkeiten, da diese durch die staatlich verordneten Sicherheitsvorkehrungen unterbunden werden konnten. Der durch die Regierung verhängte Ausnahmezustand sollte die außer Kontrolle geratene Situation im Land beruhigen. Die Autorin merkt die Bemühungen der regierenden Kräfte an, die zur Schadensbegrenzung den kommunistischen Anhängern des Landes die Schuld zuschieben wollten. Außerdem versuchte die Regierung, die September-Ereignisse durch die Erwähnung früherer Ereignisse zu verharmlosen, und zeigte laut der Autorin nur eine gespielte Anteilnahme für die Opfer.

Auf die chronologische Auseinandersetzung folgt eine Analyse der entstandenen Schäden und Zerstörung. Laut offizieller türkischer Darstellung war der entstandene Schaden geringer, als dies durch die Autorin ermittelt werden konnte. Anhand dieser offiziellen Darstellungen ließ sich wiederum die Vertuschung und Bagatellisierung durch den türkischen Staat feststellen. Dilek Güven kommt zu dem Ergebnis, dass die Schadensersatzleistungen und Spenden an die Opfer der Ereignisse oft als Ausdruck von Patriotismus und Loyalität gegenüber dem türkischen Staat gesehen wurden. Im Anschluss fügt die Autorin Fotomaterial der September-Ereignisse aus einem Archivfund des Richters Fahri Çoker hinzu, der an den Gerichtsverhandlungen zu den Ausschreitungen aktiv beteiligt war und das Material bislang unter Verschluss halten musste.

Im dritten Kapitel kommt Dilek Güven zur Erläuterung der verschiedenen Protagonisten sowie der Bedeutung der eingerichteten Sondergerichte. Die daraus resultierenden Verhaftungen und Verurteilungen lösten sowohl in der Opposition als auch in der Bevölkerung starke Kritik aus, da die eigentlichen Verantwortlichen nicht gefasst wurden. Die Forschung der Autorin brachte hervor, dass die verdächtigten Vereinigungen oftmals mit der Regierung kooperiert hatten, von ihr finanziert und gelenkt wurden, was die These der Organisation der Übergriffe auf die christliche und jüdische Bevölkerung durch die türkische Regierung stützte. Die Rolle der geheimen Sicherheitspolizei, die durch ein Bombenattentat in die Ereignisse verwickelt war, wurde in der türkischen Berichterstattung und Aufklärung bisher verschwiegen. Die Beteiligung von Regierungsmitgliedern analysiert Dilek Güven anhand von deutschen und englischen Berichten der Generalkonsulate. Geringe Ausschreitungen wurden durch Staatsmächte geplant, diese aber liefen aus dem Ruder und waren für die Staatsmächte nicht mehr kontrollierbar. Anhand verschiedenster Indizien ließ sich die Beteiligung der Regierung nachweisen. In den folgenden Gerichtsverhandlungen kam es lediglich zur Beschuldigung der damaligen Regierungsmitglieder, die geheime Sicherheitspolizei sowie der Verein „Zypern ist Türkisch“ wurden bewusst außer Acht gelassen. Dies diente der Legitimierung und Rechtfertigung des aktuellen politischen Regimes, das infolge des Militärputsches 1960 die Regierung der Türkei übernommen hatte.

Im vierten Kapitel geht die Autorin auf die Vorgeschichte der September-Ereignisse ein, um die Gründe der Ausschreitungen aufzuzeigen. Die vorangegangenen ethnischen und religiösen Homogenisierungsbestrebungen im späten Osmanischen Reich und dem jungen türkischen Staat werden von ihr als Vorläufer für diese Ereignisse gesehen. Sie ordnet die Übergriffe auf Christen und Juden also nicht als ein einzelnes Phänomen ein, sondern sieht dies strukturell und kausal in engem Bezug zu den Bestrebungen des türkischen Staates. Das Ziel war es, durch die Türkisierungsmaßnahmen die Dominanz der Nichtmuslime vor allem im wirtschaftlichen Bereich zu beenden. Der Übergang vom Vielvölkerstaat des Osmanischen Reiches mit multiethnischer Prägung zum Nationalstaat Türkei vollzog sich im Vergleich zu Vorgängen im Westen Europas relativ spät. So führten die nationalstaatlichen Homogenisierungsbestrebungen zum 


\section{europa ethnica}

Genozid an der armenischen Bevölkerung, der wiederum eine Vertreibung der griechisch-orthodoxen Bevölkerung nach sich zog. In der Siedlungspolitik der Türkei führte die Reformierung der östlichen Gebiete zu Aufständen der kurdischen Bevölkerung, die daraufhin als Bedrohung der nationalen Einheit angesehen wurde. Neben den Unabhängigkeitsbestrebungen der kurdischen Bevölkerung kam es auch in anderen Bereichen der Türkei zu Konflikten. So entwickelte sich die Situation de türkischen Minderheit auf Zypern zunehmend dazu, dass diese unter griechische Souveränität hätte geraten können. Die amtierende Regierung reagierte zunächst nicht auf den Zypernkonflikt, da die bisher freundschaftlichen Beziehungen zu Griechenland nicht belastet werden sollten. Die Zuspitzung des Konfliktes im Jahr 1954 führte jedoch dazu, dass jegliche Toleranz der türkischen Regierung gegenüber den nichtmuslimischen Minderheiten verschwand und sich letztendlich auch in den September-Ereignissen widerspiegelte. Die zunächst nur gegen die griechische Minderheit gerichteten Kampagnen wirkten sich jedoch auch auf andere Minderheiten aus.

In der abschließenden Betrachtung des Buches geht die Autorin nochmals überblicksartig auf die Ereignisse und vorangegangenen Entwicklungen des türkischen Staates ein. Dabei erwähnt sie auch die pogromartigen Übergriffe 1934 gegen die Juden in Thrakien. Die Ausschreitungen gegen Griechen und Juden im September 1955 führten zu mehreren Auswanderungswellen dieser Gruppen aus der Türkei und außerdem zu einer enormen Reduzierung der Multikonfessionalität der Stadt Istanbul. Das Ziel einer erfolgreichen homogenen türkischen Nationalstaatsbildung wurde durch diese Übergriffe stark vorangetrieben. Die Monographie von Dilek Güven stellt ein wichtiges Werk in der Aufarbeitung der Ausschreitungen gegen Minderheiten in der Türkei im Jahr 1955 dar, da dieses Thema bisher kaum wissenschaftlich objektiv aufgearbeitet wurde. Im Gegensatz zu publizistischen Darstellungen stellen ihre Analysen und Erläu terungen die Ereignisse in einen starken Zusammenhang mit den damaligen türkisch-nationalen Homogenisierungsbestre bungen. Mit ihrer Arbeit schafft die Autorin eine angemessene Darstellung, ein Konglomerat aus politischer Ereignisgeschichte und einer multiperspektivischen Rekonstruktion der Pogrome. Sie fasst die Ergebnisse sehr anschaulich und detailliert zusammen, sodass diese in den historischen Kontext der modernen türkischen Staatsgeschichte eingeordnet werden können. Mit ihrer Monographie gelingt es ihr, bisher unter Verschluss gehaltenes Beweismateriel zu veröffentlichen und die Beteiligung verschiedener Staatsmächte zu offenbaren. Die Vorgehensweise der Autorin, die zunächst mit den Erläuterungen der Ereignisse beginnt, um dann in den folgenden Kapiteln die vorausgegangenen geschichtlichen Geschehnisse und beteiligten Personen zu erläutern, ermöglicht dem Lese einen detaillierten Überblick der Thematik. Ihr Werk stellt eine schwer widerlegbare Aufklärung der Geschehnisse im September 1955 dar und ist für die Bewusstmachung der Täter- und der Opferseite von enormer Bedeutung.

Julia Jähnert

Mariana Hausleitner/Harald Roth: Der Einfluss von Faschismus und Nationalsozialismus auf Minderheiten in Ostmittel- und Südosteuropa. München: Veröffentlichungen des Instituts für deutsche Kultur und Geschichte Südosteuropa (IGKS) an der Ludwig-Maximilian-Universität München. Band 107. IGKS Verlag, 2006. € 20,50

Es sind bereits einige Jahre in das Land gezogen, seit der Sammelband Forschungen vor allem von Nachwuchswissenschaftlern und -innen am IGKS München und am SiebenbürgenInstitut in Gundelsheim/N. zu einem Ausschnitt des größeren
Forschungsdesiderats „Wahrnehmung der rechten wie linken Ideologien bei den Minderheiten in Mittel- und Südosteuropa“ zusammengefasst hat. Die gegenwärtigen Ereignisse in der Ukraine zeigen, dass das Thema nichts an Aktualität verloren hat, auch wenn die Ukraine in diesem Band nicht gesondert behandelt wird. Dafür erfährt man über „Kontinuität des Ersten Weltkrieges im Frieden? Kriegsdenkmäler und Heldenkult be den Siebenbürger Sachsen“ (Bernhard Böttcher), den „Einsatz der Deutschen aus Bessarabien beim Aufstand von Tatarbuna 1924“ (Olga Schroeder-Negru), „Die Einstellung der ungarischen Minderheit Rumäniens zu Faschismus und Nationalsozialismus 1922-1940“ (Franz Sz. Horváth), „Konfessionsspezifische Wahrnehmung des Nationalsozialismus in kirchlichen Publikationen der deutschen Minderheit in Rumänien in den 1930er Jahren“ (Cornelia Schlarb), „Sportpolitische Impulse aus dem „Dritten Reich“ und der Strandbadbau in Siebenbürgen 1936-1999“ (Thomas Şindilariu), ,Erweckung und Distanz: Aspekte der Nazifizierung der ,Volksdeutschen“ in Slawonien 1935-1940“ (Carl Bethke), „Die Donauschwaben in der Vojvodina und der Nationalsozialismus“ (Zoran Janjetović), „Rezeption der nationalsozialistischen Ideologie in Ungarn und in der deutschen Volksgruppe“ (Norbert Spannenberger, József Vonyó), „Heimatkunde, Wissenschaft und die NS-Volkstumspolitik. Die Entwicklung des Instituts für Heimatforschung in der Slowake 1941-1944“ (Christof Morrissey), „Die Moldauer Ungarn (Tschangos) im Rahmen der rumänisch-ungarisch-deutschen Beziehungen zwischen 1940 und 1944“ (Meinolf Arens, Daniel Bein), „Judengenozid in dem unabhängigen Staat Kroatien“ (Ivo Goldstein) und „Versperrte Wahrnehmung: Die Auseinandersetzung der evangelischen Kirche A. B. in Rumänien mit dem Nationalsozialismus 1944-1948“ (Pierre de Trégomain). Die Beiträge werden von Daniel Ursprung, „Faschismus in Ostmittel- und Südosteuropa: Theorien, Ansätze, Fragestellung “ souverän überspannt (S 9-52). Daniel Ursprung leistet eine begriffliche Grundlegung und entscheidet sich bei einer Vielzahl von Faschismusverständnisssen für Roger Griffins Definition von Faschismus über dessen ideologischen Kern als „palingenetic ultranationalism“ oder "third way nationalism“ (S 25-28), das heißt als „a political ideology whose mythic core in its various permutations is a palingenetic form of populist ultranationalism“ (S 25). Für Daniel Ursprung zieht dieser Begriff, weil dadurch „nicht alle Bewegungen mit einer nationalistischen Rhetorik und einem an faschistische Vorbilder gemahnenden Dekor als genuin faschistisch verstanden werden, wenn sie keine Vorstellung von einer Regeneration, einer revolutionärem Umwandlung bzw. einer Wiedergeburt entwickeln. Andererseits können Bewegungen als faschistisch erkannt werden, wenn sie den ideologischen Kern mit den klassischen faschistischen Bewegungen teilen, selbst wenn ihr Auftreten wenige Ähnlichkeiten mit diesen aufweist“ (S 27). Organisationsstruktur und äußere Erscheinungsformen spielen keine Rolle. Ursachen und Form bleiben außen vor (S 28). Doch zeigt sich Danie Ursprung auch Stanley Payne und Robert O. Paxton gegenüber offen (S 37). Anhand einer vergleichenden Analyse der Beiträge des Sammelbandes geht Daniel Ursprung der Frage nach, inwieweit ein generischer Faschismusbegriff fruchtbringend für die Erforschung des Faschismus und Nationalsozialismus in Ostmittel- und Südosteuropa sein kann (S 38-45), und verfolgt die Fragestellungen der Verfasser der Beiträge (S 45-52). Bernhard Böttcher weist anhand der Denkmäler von Rosenau, Heltau und Schäßburg sowie anhand einer Reihe von Gemeindedenkmälern nach, dass diese bis in die 1930er-Jahre hinein keine Kulisse faschistischer Manifestationen waren (S 71). Der rumänische Staat behinderte die Totenehrung der Sachsen nicht Die Minderheit zeigte sich ergeben zu ihrem Schicksal, nach 1918 
dem rumänischen Staat zugeschlagen worden zu sein (S 61) Olga Schroeder-Negrus Schilderung der Rolle der Deutschen in der Auseinandersetzung zwischen Rumänen und Slawen in Bessarabien und insbesondere beim Aufstand von Tartarbunar 1924, der 1.300 Tote, erschossen durch rumänische Armeeund Sicherheitskräfte, forderte, kommt eine über ihr eigentliches Thema deutlich hinausreichende Bedeutung zu. Sie zeigt nämlich den unmittelbaren Auslöser, warum es zur Gründung der Autonomen Moldauischen Sowjetrepublik 1924 im heutigen Transnistrien kam (S 80). Die Klüfte, die sich damals zwischen rumänischer und slawischer Bevölkerung auftaten, sind, wie der sogenannte eingefrorene Konflikt Moldavien-Transnistrien heu te zeigt, nach wie vor nicht überwunden und gewinnen vor dem Hintergrund der gegenwärtigen Ukraine-Krise neue Aktualität. Franz Sc. Horváth überzeugt mit seiner ausgewogen recherchierten Wahrnehmung des differenzierten politischen Meinungsspektrums der ungarischen Minderheit in Rumänien vor (S $91 \mathrm{f}$ ) und nach der nationalsozialistischen Machtergreifung (S 97 ff) zu Nationalsozialismus und Faschismus und weist dies beispielsweise anhand der Zeitungen „Erdélyi Lapok“ und „Brassói Lapok“ nach (auch noch für die Zeit 1934-1940) (S 115 ff, 130 f). Nach Horváth war es nicht die Ideologie sondern der allgemeine Wunsch nach Grenzrevision, den die ungarische Minderheit nach 1937/38 positiv für Drittes Reich und faschistisches Italien stimmte (S $131 \mathrm{f}$ ). Dabei zeigen sich weitreichende Parallelen zu den Deutschen Kroatiens und den Ergebnissen der Forschungen von Carl Bethke zur Nazifizierung der „Volksdeutschen“ in Slawonien 1935-1940 (S $187 \mathrm{f}$ und 216) und einem gerafften Befund von Zoran Janjetović zu den Donauschwaben in der Vojvodina (S 224-226). Letzterer zeigt auch die Folgen nach dem Vormarsch der Roten Armee auf und wer zu den Hauptleidtragenden des Gegenschlages wurde (S 233-235). Cornelia Schlarb weist anhand einer Analyse der kirchlichen Publikationen der deutschen Minderheit in Rumänien in den 1930er-Jahren nach, dass es eine konfessionsspezifische Wahrnehmung von Nationalsozialismus und Bewertung von dessen Machtergreifung gegeben hat. Dabei begrüßten die evangelischen Organe Ideologie wie Machtergreifung, während die katholischen Publikationen anfangs eine ablehnende Haltung bezogen und sich später auf die Konkordatsverhandlungen und den Abschluss des Konkordats konzentrierten und so dem Vatikan folgten (siehe das Resümee auf S 160 f). Den Kontrapunkt zu dieser Studie setzt Pierre de Trégomain, der der Auseinandersetzung der evangelischen Kirche A.B. in Rumänien mit dem Nationalsozialismus in den Jahren 1944-1948, beginnend mit dem Rücktritt von Bischof Staedel und dem erklärten Bruch mit der NS-Vergangenheit durch die nachfolgende selbst ernannte Kirchenführung (S 334), nachgeht. Der Nationalsozialismus wurde indes monopolhaft zu einem „rein kirchlichen Deutungs muster“ (S 346), machte aber eine Rehabilitierung möglich und führte zu Konsens mit den neuen Behörden (S 350).

Thomas Şindilariu zeigt anhand des Strandbadbaus in Siebenbürgen den Weg vom nationalsozialistischen Motto „Sport ist Kampf und seine Vorbereitung“ zu seiner Verwässerung aufgrund der Eigendynamik der siebenbürgisch-sächsischen Gesellschaft nach, konstatiert allerdings als Ergebnis die Zurschaustellung eines neuen nationalen Selbstbewusstseins der deutschen Minderheit mit „dem fatalen Nebenergebnis der längerfristigen Desintegration aus dem rumänischen Staatsverband“ (S 163, $181 \mathrm{f}$ ).

Norbert Spannenberger und József Vonyó halten es im Ergebnis inrer Forschungen für unmöglich, eine exakte Festlegung der Infiltration der nationalsozialistischen Ideologie in Ungarn generell und speziell in der deutschen Volksgruppe zu treffen, da die Kriterien für deren Erfassung nicht bestimmt seien (S 251).
Sie konstatieren jedoch eine Empfänglichkeit der deutschen Volksgruppe auf der propagandistischen Ebene und ein aufkeimendes kollektives Minderheitenbewusstsein nach dem 30. August 1940. Dieses Bemühen um Herstellung eines deutschen Kollektivs steht auch im Mittelpunkt der Untersuchungen von Christof Morrisey zum „unabhängigen“ slowakischen Staat der Jahre 1939-1945, wobei am Beispiel des Wirkens des Instituts für Heimatforschung der Rolle einer Legitimationswissenschaft, wiederum am Beispiel des Forscherehepaares Beranek in der Zips, besonderes Augenmerk geschenkt wird (S 258-261).

Eine höchst raffinierte und effiziente Wirkungsweise von Assimilierungsmaßnahmen zeigt die Darstellung des Schicksals der Moldauer Ungarn (Tschangos oder Tschangomagyaren), ethnisch ungarischer Gruppen insbesondere in zum heutigen Rumänien gehörenden Teilen der historischen Moldau, von Meinolf Arens und Daniel Bein, wobei allerdings der Titel des Beitrags eher irreführend ist. Den Zeitraum 1940-1944 markiert eigentlich der letztlich weitgehend fehlgeschlagene Versuch der Umsiedlung der Moldauer Tschangos, der an der damals bereits erfolgreichen Assimilation der Moldauer Tschangos als römisch-katholische Rumänen scheiterte (S 278-291). Die verdienstvoll zusammengestellten Quellen (S 292-315) betreffen aber ausschließlich den genannten Zeitraum.

Der aus dem Kroatischen von Elena Popovska übersetzte Beitrag Ivo Goldsteins geht der Infiltration der ursprünglich antiserbisch ausgerichteten Ustaša durch nationalsozialistische Ideologie und deren späterer Kooperation mit den offiziellen Vertretern aus dem Deutschen Reich bei der Vernichtung von Juden im Unabhängigen Staat Kroatien nach. Sie hatte zur Folge, dass von 1941-1945 zwischen 75\% und 80\% der Mitglieder der jüdischen Gemeinschaft getötet wurden (S 317). Nach dem kroatischen Staatsführer Pavelić hätten es sogar $100 \%$ werden sollen (S 323).

Alles in allem ein sehr empfehlenswerter Sammelband, zu dem ein Personenregister (S 351-356) und ein Autorenverzeichnis (S 357-360) den Zugang erleichtern. Der Sammelband erschien aufgrund der großen Nachfrage im Jahr 2007 in zweiter, unveränderter Auflage.

Michael Geistlinger

Nils Teifke: Das Prinzip der Menschenwürde. Zur Abwägungsfähigkeit des Höchstrangigen (Studien und Beiträge zum Öffentlichen Recht, Bd. 8), Tübingen, Mohr Siebeck, 2011, 200 S. $€ 74,-(D) / € 76,10$ (A)

Das Problem, ob die Menschenwürde absolut zu setzen sei oder in Relation zu gewissen Maßstäben Gültigkeit besitzt, ist der Gegenstand vieler Diskussionen. Auch die Frage, ob in die Menschenwürde unter bestimmten Umständen eingegriffen werden kann, muss einer Antwort zugeführt werden.

Teifke wurde mit seinem Werk Das Prinzip der Menschenwürde promoviert und stellt einen Entwurf vor, in dem die Menschenwürde als ein ideell-abstrakter Überbau mit zweifachem Entwicklungspotenzial gesehen wird. In seinen Ausführungen bezieht sich der Autor besonders auf aktuelle deutsche und klassische philosophische Literatur. Fundamental für Teifkes Arbeit ist das Anschließen an die Prinzipientheorie von Robert Alexy, der in Art. 1 Abs. 1 GG einen Regel- und einen Prinzipiencharakter definiert.

Das vorliegende Werk ist in drei Teile gegliedert. Im ersten geht es um die Darstellung der Debatte um die Menschenwürde. Dabei bezieht sich Teifke auf die Rechtsprechung des Bundesverfassungsgerichts und auf den literarischen Diskurs. In der Folge führt er kritische Fragen an, die als , ungelöste Probleme“ übertitelt werden. Der Autor zeigt auf, dass es juristisch möglich ist, die 


\section{europaethnica}

Menschenwürde absolut und als Abwägungskonstrukt zu deuten. Der zweite Teil enthält Teifkes Strukturanalyse und ist in die Prinzipientheorie als normtheoretisches Fundament und die prinzipientheoretische Analyse des Streits um die Menschenwürde gegliedert. Leitende Fragen sind: Gilt die Menschenwürde als Grundrecht absolut? Ist dieses Grundrecht eine Regel oder ein Prinzip? Wird ein enger oder weiter Tatbestand aufgewiesen? Der Autor kommt zu dem Schluss, dass die Menschenwürde rechtstheoretisch keine absolute Geltung genießt, sehr wohl aber der Eindruck eines absoluten Rechtsgutes erhalten bleibt Im dritten Teil entwickelt Teifke eine Theorie der Menschenwürde und setzt dabei drei Akzente: die Elemente eine Menschenwürdetheorie, die These vom Doppelcharakter und Definitionen im Kontext von Schutzbereich, Eingriff und Menschenwürdegesetz. Der Autor lehnt eine umfangreiche Theorie der Menschenwürde ab, weil sowohl Begriff als auch Begründung noch zu konkretisieren seien.

Teifke ist es mit seiner Arbeit gelungen, einen zeitgemäßen und globalen Diskurs neu zu bewerten. Dessen ungeachtet braucht der Leser einiges an Grundlagenwissen, um dem Autor und seinen Gedanken folgen zu können. Vor allem tiefergehende Kenntnisse in der Philosophie, der Prinzipientheorie und über die Genese der Menschenwürdediskussion sollten keinesfalls fehlen. Auf diese Weise richtet sich das Werk primär eher an Fachkollegen.

Andreas Raffeiner

Markus Thiel (Hg.): The ,Militant Democracy“ Principle in modern Democracies. London, Ashgate, 2009, 428 S. £ 90,-

Zum Autor: Markus Thiel (* 1973) studierte von 1992 bis 1996 an der Uni Köln Rechtswissenschaften und in Speyer von 1999 bis 2000 Verwaltungswissenschaften an der Deutschen Hochschule für Verwaltungswissenschaften. Nach den Promotionen 1999 zum Dr. iur. bzw. 2003 zum Dr. rer. publ. ist Thiel am Lehrstuhl für öffentliches Recht und Verwaltungslehre (Prof. Dr. J. Dietlein) tätig. Nach der Habilitation 2010 (Die „Entgrenzung“ der Gefahrenabwehr. Grundfragen von Freiheit und Sicherheit im Zeitalter der Globalisierung) ist Thiel derzeit als Privatdozent mit den Themenschwerpunkten Öffentliches Recht, Verfassungsgeschichte und Verwaltungswissenschaften an der Heinrich-Heine-Universität in Düsseldorf tätig.

Im Jahre 2009 gab Thiel im renommierten Londoner Verlag Ashgate einen Sammelband gemeinsam mit zahlreichen $\mathrm{Au}$ torinnen und Autoren heraus, der das Prinzip der „streitbaren Demokratie“ in modernen Demokratien zum Inhalt hat. Dieser Grundsatz sieht den Schutz der freiheitlich-demokratischen Grundordnung dadurch gewährleistet, dass gegen verfassungsfeindliche Personen oder Gruppierungen vorgegangen werden kann. In Deutschland kann das vor allem durch die Frage nach einem NPD-Verbot akzentuiert werden, und gerade diese Frage ist es, die immer wieder ein Auslöser für Diskussionen über das Thema einer „streitbaren Demokratie“ ist. Doch auch „von außen“, ja international werden Demokratien bedroht. Dazu zählen u.a. der Terrorismus, die Cyberkriminalität oder Vorstöße rechts- bzw. linksextremer Gruppierungen.

Mit dem vorliegenden Sammelband setzt Thiel keineswegs bloß bei seinem Vorwerk aus dem Jahr 2003 nahtlos an, sondern bietet der Wissenschaft neue Möglichkeiten zur Forschung und Auseinandersetzung mit der komplex scheinenden Materie, die bisher in wenigen Studien Berücksichtigung gefunden hat. Dem Herausgeber gelang es, einen internationalen Kreis von Expertinnen und Experten zu versammeln, um 13 Länderstudien zu präsentieren. Mehr noch: Er führt in seinen einleitenden Worten die derzeitigen Konfliktpotenziale streitbarer Demokratien anschaulich aus und verweist auf die Problematik internationaler Rechtsvergleiche.
Danach rückt die Analyse der gesetzmäßigen Kernelemente internationaler, streitbarer Demokratien in den Vordergrund. So werden u.a. Deutschland, Österreich, Frankreich, Chile, Spanien, die USA, Großbritannien und die Türkei berücksichtigt. Nach der Analyse folgt das Schlusskapitel, das aus der Feder von Thiel selbst stammt. Man kann dieses gut und gerne auch als Zusammenfassung betrachten. Hier schreibt der Herausgeber, dass die Länderstudien Darstellungen zur Genese der verfassungsrechtlichen Systeme, zum länderspezifischen Demokratieschutz, zu politischen und historischen Zusammenhängen und zu den essenziellsten Rechtsgrundlagen enthalten. Leider fehlt eine überzeugende Begründung, weshalb sich Thiel gerade auf jene Länderauswahl beschränkt. Dies lässt den Eindruck einer Beliebigkeit entstehen. Nichtsdestotrotz liefert der Herausgeber ein akkurat recherchiertes und stabiles Fundament, auf welchem der internationale Demokratieschutz durch Rechtssysteme verglichen werden kann.

Der Herausgeber hat eine Systematisierung geschaffen, die weitere Forschungen erfordert und mit sich bringt. Eine Theoriebildung wird dabei nicht vorgenommen und demzufolge keineswegs angestrebt. Das Herausgeberwerk Thiels unterstreicht die Vielfalt des Prinzips streitbarer Demokratien. Dadurch kann man sagen, dass der Ambition, einen ausführlichen Sammelband zu publizieren, Genüge getan wird.

Andreas Raffeiner

Jürgen Trabant: Globalesisch oder was? Ein Plädoyer für Europas Sprachen. München, Beck, 2014, 235 S. € 18,95.

Jürgen Trabant ist einer der renommiertesten Sprachwissenschaftler im Bereich der Romanistik und war lange Zeit Ordinarius an der Freien Universität Berlin. Er hat viel über sprachphilosophische Fragen publiziert; zuletzt hatte er bis 2013 an der Jacobs Universität in Bremen eine Professur für Europäische Mehrsprachigkeit inne. Vor allem das ungeheure Werk Wilhelm von Humboldts hat es inm angetan, die Lektüre seiner Arbeiten zur Sprachkonzeption des Schöpfers der Berliner Universität ist nicht nur ein Erkenntnisgewinn, sondern immer auch ein ästhetisches Vergnügen (zuletzt: Weltansichten. Wilhelm von Humboldts Sprachprojekt. München, Beck, 2012). Diese wissenschaftlichen Interessen Trabants erklären, dass er der Generativen Grammatik und ihren Grundannahmen, wie sie von Noam Chomsky und seinen Anhängern vertreten werden, nur wenig abgewinnen kann. Zwar wird niemand verkennen, dass diese Richtung gewisse Fortschritte in der Sprachwissenschaft gebracht hat, seit geraumer Zeit ist sie indes an vielen Orten zur „herrschenden Lehre“ geworden, die für andere sprachwissenschaftliche Traditionen und ihre Erkenntnisgewinne nur wenig Verständnis aufbringt und daher den Austausch mitunter erschwert. Das hängt nicht zuletzt damit zusammen, dass der Generativismus aufgrund seiner biologistischen Grundeinstellung von einer Konzeption des sprachlichen Universalismus ausgeht, d.h. von einer Konzeption, der zufolge alle Sprachen letztlich in gleicher Weise aufgebaut seien, und damit vergleichsweise wenig Interesse an sprachlicher Vielfalt, an den Bezügen zwischen Sprechen/Kommunizieren und Denken, aber auch an sprachsoziologischen Fragestellungen hat.

Genau diesem Problem wendet sich das neue Werk Trabants zu. Er sagt, dass die verkündete Politik der Mehrsprachigkeit, etwa der Europäischen Union, in Wirklichkeit auf die, sogar relativ rasche, wie er befürchtet, Durchsetzung eines diglossischen Kommunikationsmonopols des Englischen hinauslaufe. Er beginnt mit der Kritik einer Rede des deutschen Bundespräsidenten Gauck, der „Mehrsprachigkeit für immer größere Bevölkerungsgruppen“ (S. 12) fordert. Trabant notiert dazu trocken: 
„Mit ,Mehrsprachigkeit“ ist hier - wie fast immer im derzeitigen öffentlichen Diskurs über Sprachen - nur das Beherrschen des Englischen gemeint“ (ibid.). Er geht davon aus, dass das derzeit praktizierte Modell dazu führt, dass sich auf die Dauer eine europäische Diglossie aufbaut, mit einer dominanten Sprache - Englisch - und vielen dominierten Sprachen - gewöhnlich den bisherigen Staatssprachen; seine Befürchtungen laufen weiter darauf hinaus, dass die meisten Nicht-Staatssprachen völlig von der Bildfläche verschwinden werden.

Implizit sagt Trabant damit auch, dass die verkündete europäische Sprachenpolitik nicht ehrlich sei, weil die, die sie propagieren, sie nicht anwenden: Wann hat Manuel Barroso eine seine Brüsseler Reden auf Portugiesisch gehalten? Wann tritt einer der Kommissare vor die Presse und spricht in seiner Sprache um sich dann übersetzen zu lassen? Die Beispiele ließen sich vervielfachen, und nicht nur auf dieser eher anekdotischen Ebene. Ich habe selbst bisweilen auf diese Widersprüche hingewiesen, zuletzt in Europa Ethnica, 2013, 106-109.

Man wird in der Analyse der Situation zwischen den Repräsentanten verschiedener Richtungen unterscheiden müssen, nämlich zum einen zwischen denen, die tatsächlich auf längere Sicht ein Europa anstreben, das sich nur noch auf Englisch miteinander verständigt, und denen, die subjektiv wirklich eine Mehrsprachigkeitskonzeption vertreten, objektiv sich jedoch vielfach kontraproduktiv dazu verhalten. Dazwischen ist etlicher Raum für Zwischenpositionen. Nur vereinzelt wird derzeit nach einer Re-Diversifizierung des sprachlichen Settings gerufen, vermutlich, weil niemand glaubt, die Bewegung derzeit aufhalten zu können. Auch ein - heute nicht mehr völlig auszuschließender - Austritt Großbritanniens aus der EU wird an dieser Entwicklung wenig ändern.

Trabant befürchtet, dass diese Entwicklung weitergeht und letztlich tatsächlich zu einer erneuten europäischen Diglossie führt: Zuletzt gab es sie im Mittelalter in Westeuropa, als das Latein für mehrere Jahrhunderte als (fast) ausschließlich geschriebene Sprache verwendet wurden, während die anderen Sprachen (fast) nur mündlich verwendet wurden und nicht als wirkliche Sprachen angesehen wurden: Die Bezeichnung lingua wurde so gut wie nie auf sie angewendet, an ihre Stelle traten Termini wie etwa idioma, sermo oder loquela u.a.

Trabant teilt seine Analyse in drei große Teile: „Heute“ - „Ge stern“ - „Morgen“. Auf nur 200 Seiten gibt er dabei ein großes Panorama der (west)europäischen Sprachengeschichte, von der mittelalterlichen Diglossie zur Emanzipation der (Herrschafts-)Sprachen seit der Renaissance und zur Verknüpfung der Termini Sprache und Nation seit der Französischen Revolution. Er weist eindringlich darauf hin, dass die Entfaltung der europäischen Sprachen (und man könnte hinzufügen: auch der Sprachen auf den anderen Kontinenten, die sich eine gewisse Position sichern konnten) einen riesigen Wissens- und Kreativitätsschub mit sich brachte. Er zeigt aber auch, dass die effektive monopolistische Durchsetzung von Staatssprachen in den meisten Teilen Europas seit dem 19. Jahrhundert dazu führte, dass andere Sprachen an den Rand gedrängt, ihre Sprecher benachteiligt und ihr Kommunikationsrahmen eingeschränkt wurde. Dabei lässt er immer auch die philosophischen Hintergründe der verschiedenen sprachenpolitischen Richtungen erkennen, auf elegante und auf das Wichtigste reduzierte Weise. Im Teil „Gestern“ geht er ausführlich au die unterschiedlichen Sprachkonzeptionen in Frankreich und Deutschland ein, die letztlich zu ähnlichen Resultaten, nämlich der weitgehenden Durchsetzung einer Sprache im jeweiligen Staat, geführt haben (es ist für den auswärtigen Beobachter immer wieder faszinierend, aber auch erschreckend, zu sehen, wie der Rückgang der sogenannten Regionalsprachen in Fran- kreich - wenigstens aus der Sicht des Zentrums Paris - fast ausschließlich positiv konnotiert wird, nicht einmal der Ansatz einer Bilanzierung wird versucht)

Im dritten Teil „Morgen“ seines Buches skizziert Trabant zunächst einige mögliche Szenarien für die Zukunft. Dabe stützt er sich vor allem auf die Visionen einiger zeitgenössischer Sprach- und Gesellschaftstheoretiker. Man wird die komplexe Situation auf eine vergleichsweise simple Frage reduzieren können: Ist/War Babel ein Glück oder ein Unglück für die Menschen? Ein Unglück, weil die zuvor bestehende Kommunikationsgemeinschaft aufgehoben wurde. Aber: Schützt das Monopol einer Sprache vor Interessenkonflikten? Verstehen wir unsere Unterschiede in einer Sprache besser? Die traurige Erkenntnis, dass Bürgerkriege immer zu den grausamsten Auseinandersetzungen zwischen Gruppen gehören, lässt zumindest Zweifel aufkommen. Ein Glück, weil es die menschliche Kreativität befreite und den Menschen erlaubt, die sie umgebende Realität auf sehr unterschiedliche Weise wahrzunehmen. Nicht zuletzt wissen wir heute, dass die Mehrheit der Menschen in irgendeiner Weise mehrsprachig ist. Es gilt indes das Paradox: Sprachenlernen ist mühsam, und es ist immer wenig attraktiv, solange der Lernende nicht eine konkrete Kommunikationsmöglichkeit vor sich sieht - dann aber ist die Kommunikationsnotwendigkeit eine unmittelbare, die nicht durch einen langen Lernprozess hindurchgehen kann. Wir wissen ja gewöhnlich nicht, welche Sprachen wir einmal können sollten. Auf der anderen Seite: Es ist immer bereichernd, Sprachen zu lernen, und je mehr Sprachen ich spreche, desto leichter wird der Erwerb von weiteren.

Einen nicht unwichtigen Gedanken breitet Trabant im letzten Kapitel seines Werkes aus: Die sprachliche Assimilation an eine dominante Sprache würde neue Ungerechtigkeiten mit sich bringen, denn nie stehen alle der herrschenden Sprache - ob es nun Englisch ist, wie es heute scheint, oder eine andere, wie veränderte weltpolitische Konstellationen es relativ schnell mit sich bringen könnten - gleich nahe. Daher wird die Ungleichheit immer weiter gehen. Wer je in Brüssel an einer der unendlich vielen und ebenso wichtigen Sitzungen teilgenommen hat, kennt diese Realität; sie wird auch aus anderen internationalen Kontexten berichtet, in denen nur eine Sprache als Arbeitssprache verwendet wird.

Als einen Ausweg aus dem Dilemma schlägt er mit einigem Nachdruck ein Konzept der „Brudersprache“ vor, die jeder Europäer sich neben seiner Staatssprache und dem Englischen aneignen und mit Nachdruck pflegen sollte. Damit fände die of fizielle Forderung der EU nach Dreisprachigkeit ihrer Bürger eine praktische Umsetzung. Ich könnte noch eine weitere Anregung hinzufügen: Neben den Sprachen, die wir beherrschen lernen, sollte die Sprachvermittlung in viel stärkerem Maße unsere rezeptiven und kombinatorischen Fähigkeiten schulen, die es uns erlauben, uns in viel mehr Sprachen zu bewegen, als wir uns zunächst träumen lassen; vor allem innerhalb von „Sprachfamilien“ zeitigen solche Versuche oft erstaunliche Erfolge.

Trabants Befürchtungen hinsichtlich der (nicht nur) europäischen Entwicklungen im Hinblick auf Sprachenvielfalt gehen sehr weit. Auch er sieht indes noch Möglichkeiten zu einer Kursänderung. Werden sie genutzt werden? Zu wünschen wäre es. Um anzudeuten, worum es Trabant eigentlich geht (und darin kann ich ihm leicht folgen), sei an das Ende dieser Vorstellung ein Satz aus dem letzten Kapitel gestellt: „Sprache ist aber auch - und das ist ihre eigentlich menschliche Seite - eine Technik zur geistigen Bearbeitung der Welt, zum ,Denken“ der Welt. Hierfür hat der Mensch die komplizierte Technik der Sprache erfunden." Hoffentlich verspielt er sie nicht.

Georg Kremnitz 